\title{
QUANTITY AND QUALITY OF GROUND-WATER DISCHARGE TO THE SOUTH PLATTE RIVER, DENVER TO FORT LUPTON, COLORADO, AUGUST 1992 THROUGH JULY 1993
}

by Peter B. McMahon, Kenneth J. Lull, Kevin F. Dennehy, and Jim A. Collins

U.S. GEOLOGICAL SURVEY

Water-Resources Investigations Report 95-4110

Prepared in cooperation with the

METRO WASTEWATER RECLAMATION DISTRICT, DENVER, COLORADO 


\section{U.S. DEPARTMENT OF THE INTERIOR \\ BRUCE BABBITT, Secretary}

U.S. GEOLOGICAL SURVEY

Gordon P. Eaton, Director

The use of trade, product, industry, or firm names is for descriptive purposes only and does not imply endorsement by the U.S. Government.

For additional information write to:

Copies of this report can be purchased from:

District Chief

U.S. Geological Survey

Box 25046, MS 415

Denver Federal Center

Denver, CO 80225
U.S. Geological Survey

Earth Science Information Center

Open-File Reports Section

Box 25286, MS 517

Denver Federal Center

Denver, CO 80225 


\section{CONTENTS}

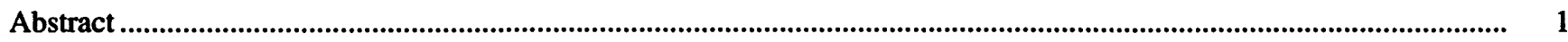

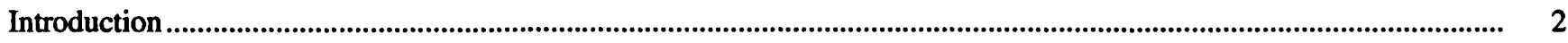

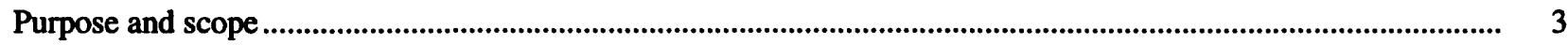

Background hydrology and description of study area .................................................................................................. 3

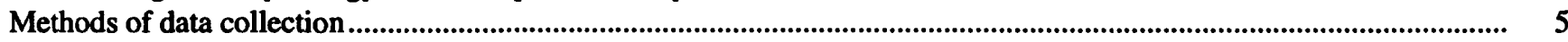

Discharge measurements....................................................................................................................................... 5

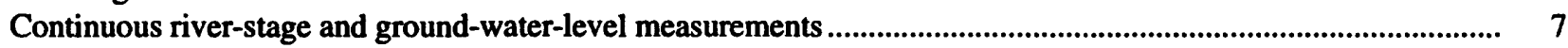

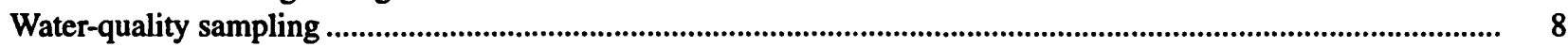

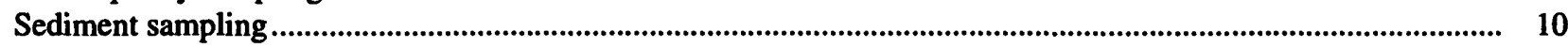

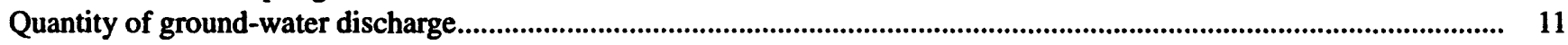

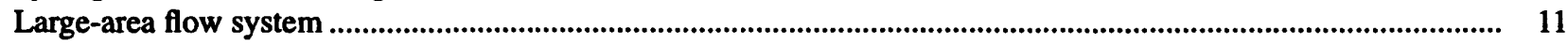

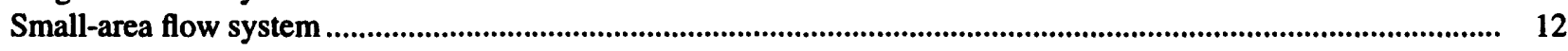

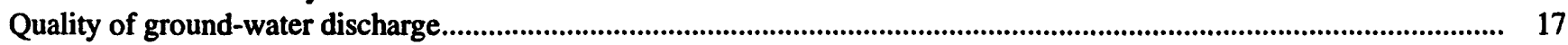

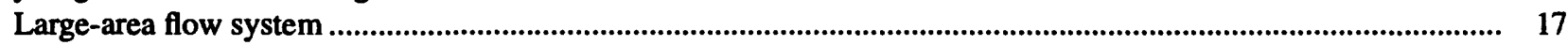

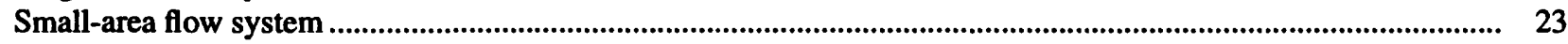

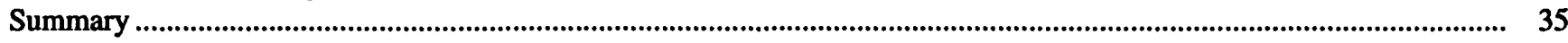

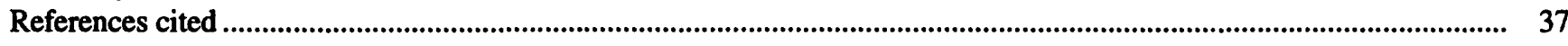

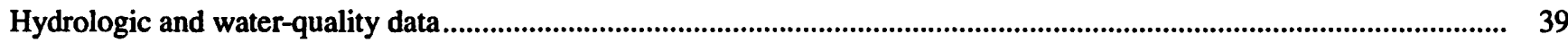

\section{PLATE}

[In pocket]

1. Map showing location of sampling sites in study area

\section{FIGURES}

1-18. Graphs showing:

1. Mean monthly discharge at two streamflow-gaging stations on the South Platte River between Denver and Fort Lupton

2. (A) Daily fluctuations in discharge from the Metro Wastewater Reclamation District effluent outfalls, and (B) daily changes in river stage at Henderson and Road 8.

3. Difference in altitude between surface water and water in the $1 \mathrm{~A}$ wells at Henderson and Road 8

4. Rate of instantaneous ground-water discharge across the sediment/water interface with (A) time, and (B) distance downstream from the Metro Wastewater Reclamation District effluent outfalls

5. Rate of instantaneous ground-water discharge across the sediment/water interface with time in the South Platte River at (A) McKay Road on January 24 and 25, 1993; (B) Henderson on January 26 and 27, 1993; and (C) Road 8 on November 18 and 19, 1992.

6. Values of $\mathrm{pH}$ in water from wells at McKay Road, Henderson, and Road 8 .

7. Average difference in $\mathrm{pH}$ between ground water and surface water, by well, at McKay Road, Henderson, and Road 8.

8. Concentrations of dissolved oxygen in water from wells at McKay Road, Henderson, and Road 8

9. Concentrations of dissolved nitrite plus nitrate in water from wells at McKay Road, Henderson, and Road 8

10. Concentrations of dissolved ammonium in water from wells at McKay Road, Henderson, and Road 8. 
11. Concentrations of dissolved phosphorus in water from wells at McKay Road, Henderson, and Road 8

12. Values of $\mathrm{pH}$ in (A) ground water 1 foot below the sediment/water interface with time, and (B) surface water and ground water 1 foot below the sediment/water interface with distance downstream from the Metro Wastewater Reclamation District effluent outfalls

13. Values of $\mathrm{pH}$ in ground water with depth below the sediment/water interface at McKay Road, Henderson, and Road 8.

14. Concentrations of dissolved oxygen in ground water 1 foot below the sediment/water interface with (A) distance downstream from the Metro Wastewater Reclamation District effluent outfalls, and $(B)$ time

15. Concentrations of dissolved oxygen and differences in hydraulic head between ground water and surface water with depth below the sediment/water interface.

16. Concentrations of total organic carbon in ground water with depth below the sediment/water interface at McKay Road, Henderson, and Road 8

17. Concentrations of (A) dissolved nitrite plus nitrate, and (B) dissolved ammonium in ground water 1 foot below the sediment/water interface with distance downstream from the Metro Wastewater Reclamation District effluent outfalls

18. Concentrations of (A) dissolved nitrite plus nitrate and ammonium and the $\delta^{15} \mathrm{~N}$ composition of dissolved ammonium, and (B) concentrations of dissolved phosphorus in ground water with depth below the sediment/water interface at McKay Road on November 2, 1992

\section{TABLES}

1. Surface-water sites at which discharge was measured

2. Location of cross-section sites at which ground-water discharge was measured

3. Construction details for monitoring wells at the McKay Road, Henderson, and Road 8 sites.................................

4. Water balance for selected reaches of the South Platte River on selected dates

5. Percent of grain sizes less than 0.079 inch and percent organic matter in 0.079 -inch size fraction for riverbed and aquifer sediments at McKay Road, Henderson, and Road 8

6. $\delta^{15} \mathrm{~N}$ compositions of dissolved nitrate in surface water and ground water, and $\delta^{15} \mathrm{~N}$ compositions of solid and dissolved ammonium in surface water and ground water

7. Rates of nitrous oxide production measured in laboratory incubations of riverbed and aquifer sediments

8. Discharge at selected surface-water sites on selected dates.

9. Rates of ground-water discharge across the sediment/water interface and quality of surface water and ground water 1 foot below the sediment/water interface at cross-section sites.

10. Water-quality data for water from the South Platte River, piezometers, and wells at McKay Road, Henderson, and Road 8

11. Quality-assurance/quality-control data for major-ion, nutrient, iron, and manganese analyses 


\section{CONVERSION FACTORS}

\section{Multiply}

cubic foot per second $\left(\mathrm{ft}^{3} / \mathrm{s}\right)$ foot (ft)

gallon per minute ( $\mathrm{gal} / \mathrm{min}$ ) inch (in.) mile (mi)
By

0.02832

0.3048

3.785

25.4

1.609
To obtain

cubic meter per second

meter

liter per minute

millimeter

kilometer

Degree Celsius $\left({ }^{\circ} \mathrm{C}\right)$ may be converted to degree Fahrenheit $\left({ }^{\circ} \mathrm{F}\right)$ by using the following equation:

$$
{ }^{\circ} \mathrm{F}=9 / 5\left({ }^{\circ} \mathrm{C}\right)+32 \text {. }
$$

The following abbreviations also are used in the report:

cubic foot per second per mile $\left[\left(\mathrm{ft}^{3} / \mathrm{s}\right) / \mathrm{mi}\right]$

liter (L)

micrometer $(\mu \mathrm{m})$

microsiemens per centimeter at 25 degrees Celsius $(\mu \mathrm{S} / \mathrm{cm})$

milligram (mg)

milligram per liter (mg/L)

milliliter $(\mathrm{mL})$

millimoles per liter $(\mathrm{mmol} / \mathrm{L})$

million cubic feet per day per mile $\left[\left(\mathrm{Mft}^{3} / \mathrm{d}\right) / \mathrm{mi}\right]$

nanomoles per gram of dry sediment per day $(\mathrm{nmol} / \mathrm{gdw} / \mathrm{d})$

Sea level: In this report "sea level" refers to the National Geodetic Vertical Datum of 1929 (NGVD of 1929)_a geodetic datum derived from a general adjustment of the first-order level nets of both the United States and Canada, formerly called Sea Level Datum of 1929. 
偊 


\title{
Quantity and Quality of Ground-Water Discharge to the South Platte River, Denver to Fort Lupton, Colorado, August 1992 Through July 1993
}

\author{
By Peter B. McMahon, Kenneth J. Lull, Kevin F. Dennehy, and Jim A. Collins
}

\section{Abstract}

Water-quality studies conducted by the Metro Wastewater Reclamation District have indicated that during low flow in segments of the South Platte River between Denver and Fort Lupton, concentrations of dissolved oxygen are less than minimum concentrations set by the State of Colorado. Low dissolved-oxygen concentrations are observed in two reaches of the river - they are about 3.3 to 6.4 miles and 17 to 25 miles downstream from the Metro Wastewater Reclamation District effluent outfalls. Concentrations of dissolved oxygen recover between these two reaches. Studies conducted by the U.S. Geological Survey have indicated that ground-water discharge to the river may contribute to these low dissolved-oxygen concentrations. As a result, an assessment was made of the quantity and quality of ground-water discharge to the South Platte River from Denver to Fort Lupton. Measurements of surface-water and ground-water discharge and collections of surface water and ground water for water-quality analyses were made from August 1992 through January 1993 and in May and July 1993. The quantity of groundwater discharge to the South Platte River was determined indirectly by mass balance of surfacewater inflows and outflows and directly by instantaneous measurements of ground-water discharge across the sediment/water interface in the river channel. The quality of surface water and ground water was determined by sampling and analysis of water from the river and monitoring wells screened in the alluvial aquifer adjacent to the river and by sampling and analysis of water from piezometers screened in sediments underlying the river channel.
The ground-water flow system was subdivided into a large-area and a small-area flow system. The precise boundaries of the two flow systems are not known. However, the large-area flow system is considered to incorporate all alluvial sediments in hydrologic connection with the South Platte River. The small-area flow system is considered to incorporate the alluvial aquifer in the vicinity of the river. Flow-path lengths in the large-area flow system were considered to be on the order of hundreds of feet to more than a mile, whereas in the small-area flow system, they were considered to be on the order of feet to hundreds of feet. Mass-balance estimates of incremental ground-water discharge from the large-area flow system ranged from -27 to 17 cubic feet per second per mile in three reaches of the river; the median rate was 4.6 cubic feet per second per mile. The median percentage of surface-water discharge derived from ground-water discharge in the river reaches studied was 13 percent. Instantaneous measurements of ground-water discharge from the small-area flow system ranged from $-1,360$ to 1,000 cubic feet per second per mile, with a median value of -5.8 cubic feet per second per mile. Hourly measurements of discharge from the small-area flow system indicated that the high rates of discharge were transient and may have been caused by daily fluctuations in river stage due to changing effluent-discharge rates from the Metro Wastewater Reclamation District treatment plant. Higher river stages caused surface water to infiltrate bed sediments underlying the river channel, and lower river stages allowed ground water to discharge into the river. Although stage changes apparently cycled large quantities of water in and out of the small-area flow system, the process probably provided no net gain or loss of 
water to the river. In general, mass balance and instantaneous measurements of ground-water discharge indicated that the ground-water flow system in the vicinity of the river consisted of a large-area flow system that provided a net addition of water to the river and a small-area flow system that cycled water in and out of the riverbed sediments, but provided no net addition of water to the river. The small-area flow system was superimposed on the large-area flow system.

The median values of $\mathrm{pH}$ and dissolved oxygen in ground water from the large-area flow system were 7.16 and 0.9 milligrams per liter. These values were lower than values for river water, indicating that the discharge of ground water from the large-area flow system would lower values of $\mathrm{pH}$ and concentrations of dissolved oxygen in the river. Concentrations of dissolved nitrite plus nitrate, ammonium, and phosphorus in ground water from the large-area flow system varied between monitoring-well sites. The highest concentrations of nitrite plus nitrate (maximum concentration of 37.93 milligrams per liter as nitrogen) were measured in water from wells along the downstream river reach where relatively low concentrations of dissolved oxygen occurred in the river. The highest concentrations of ammonium and phosphorus (maximum concentrations of 9.2 milligrams per liter as nitrogen and 7.24 milligrams per liter as phosphorus) were measured in water from wells along the upstream river reach where relatively low concentrations of dissolved oxygen occurred in the river. The waterquality data indicate that ground-water discharge from the large-area flow system may have been a source of nitrite plus nitrate to the downstream river reach and a source of ammonium and phosphorus to the upstream river reach.

The median values of $\mathrm{pH}$ and dissolved oxygen in ground water from the small-area flow system were 7.33 and 0.2 milligrams per liter. The dissolved-oxygen data indicate that sediments in the small-area flow system were a sink for dissolved oxygen in water discharging to the river from the large-area flow system and in surface water infiltrating into the bed sediments. These data indicate that even though the small-area flow system was not a net source of water to the river, it did have the potential to lower concentrations of dissolved oxygen in the river as river water cycled in and out of the bed sediments. Chemical and isotopic data indicate that organic-rich bed sediments in the upstream river reach were a source of ammonium and phosphorus to water in the smallarea flow system; therefore, the small-area flow system may have been a source of ammonium and phosphorus to the river even though it was not a net source of water to the river. Laboratory measurements of denitrification in bed sediments from below the river indicate that sediments in the small-area flow system also were a potential sink for nitrate in the large-area flow system and in the river as a result of microbial denitrification in the sediments. The widespread distribution of sources and sinks of dissolved-nitrogen and -phosphorus species made it difficult to determine how much nitrogen and phosphorus were entering the river from ground-water discharge.

\section{INTRODUCTION}

The South Platte River between Denver and Fort Lupton has been designated by the Colorado Department of Health and Environment, Water Quality Control Commission (WQCC), as an Aquatic Life Warm Water Class 2 river (Colorado Department of Health and Environment, 1993). As such, the WQCC has set minimum 24-hour average dissolved-oxygen (DO) concentrations of $5.0 \mathrm{mg} / \mathrm{L}$ from May through July and $4.5 \mathrm{mg} / \mathrm{L}$ from August through April to sustain aquatic life in the river. Water-quality studies conducted by the Metro Wastewater Reclamation District (MWRD) have indicated that segments of this reach do not meet the DO standards during some periods of low flow. Although effluent discharged from the MWRD central plant has been identified as an important contributing factor in the DO depletion (Camp Dresser and McKee, Inc., 1992), other unrelated processes also may affect DO concentrations in the river during low flow. Other sources of water to the river include ungaged surface runoff, tributary inflows, and ground-water discharge. Previous work conducted by the U.S. Geological Survey (USGS) indicates that ground-water discharge to this reach of the South Platte River is a substantial source of water to the river when runoff and tributary inflows are at a minimum (Hurr and Schneider, 1972) and that biological reactions in riverbed sediments at the interface between surface water and ground water are an important sink for DO in ground-water discharge (P.B. McMahon, U.S. Geological Survey, unpublished data, 1993). Discharge of DO-depleted ground water may contribute to the low DO concentrations in the South Platte 
River downstream from Denver. In 1992, the USGS, in cooperation with the MWRD, began a study of the quantity and quality of ground-water discharge to this reach of the South Platte River.

\section{Purpose and Scope}

This report describes the quantity and quality of ground-water discharge in a reach along the South Platte River from Denver to Fort Lupton. Physical and biochemical processes that affected the quantity and quality of ground-water discharge to the South Platte River also are discussed. This report presents (1) measurements of surface-water discharge rates at 14 sites and measurements of ground-water discharge rates at 30 cross sections in the river, (2) continuous measurements of ground-water levels relative to river stage at two locations in the study area, (3) water-quality data for water samples collected from 30 locations in the river, and (4) water-quality data for water samples collected from 12 monitoring wells screened in the alluvial aquifer immediately adjacent to the river and from 159 (150 single-depth and 9 multi-depth) shallow piezometers screened in bed sediments underlying the river. Data were collected from August 1992 through January 1993 and in May and July 1993.

\section{Background Hydrology and Description of Study Area}

The study area is a 26-mi reach of the South Platte River and the adjacent alluvial aquifer between 64th Avenue in Denver and Highway 52 in Fort Lupton (pl. 1). Land use in the vicinity of the river is predominantly urban between 64th Avenue and 88th Avenue and is predominantly irrigated agriculture and mining for sand and gravel in the South Platte alluvium between 88th Avenue and 124th Avenue, whereas irrigated agriculture is most important between 124th Avenue and Highway 52. An exception to the agricultural setting downstream from 124th Avenue is the city of Brighton, located near 160th Avenue.

Based on long-term surface-water discharge measurements at the South Platte River at 64th Avenue at Commerce City streamflow-gaging station (station number 06714215) and the South Platte River at Henderson streamflow-gaging station (station number 06720500) (fig. 1), the low-flow period for this reach of the South Platte River extends from about September through March. The two most important features affecting surface-water discharge in the study area during periods of low flow are effluent discharges from the MWRD treatment plant and surface-water diversions to irrigation ditches. Rates of effluent discharge from the MWRD plant vary daily from about 80 to $250 \mathrm{ft}^{3} / \mathrm{s}$ and generally peak about noon. The MWRD effluent is discharged to the river from two points-the north complex outfall and the south complex outfall. The two discharge points are located side by side. The north complex has a design capacity of about $110 \mathrm{ft}^{3} / \mathrm{s}$, and the south complex has a design capacity of about $177 \mathrm{ft}^{3} / \mathrm{s}$. In addition to effluent discharge from the MWRD plant, inflows to this reach of the South Platte River include effluent discharges from the South Adams County (design capacity of $6.7 \mathrm{ft}^{3} / \mathrm{s}$ ) and the city of Brighton (design capacity of $4.1 \mathrm{ft}^{3} / \mathrm{s}$ ) wastewater-treatment plants and include tributary inflows from Sand Creek, Clear Creek, Niver Creek, and Big Dry Creek (pl. 1).

lrrigation ditches in the study area generally operate from May through the middle of October. However, the Burlington Ditch, located about $1 \mathrm{mi}$ upstream from the MWRD plant, diverts water from the river from October through March for storage in reservoirs. The Burlington Ditch has a water right in excess of $350 \mathrm{ft}^{3} / \mathrm{s}$ (Camp Dresser and McKee, Inc., 1992); therefore, it can potentially divert all of the flow in the South Platte River during periods of low flow. At these times, discharge of effluent from the MWRD plant may constitute more than 90 percent of the river downstream from the MWRD plant. Four ditch systems downstream from the MWRD, the Fulton (water right $>200 \mathrm{ft}^{3} / \mathrm{s}$ ), Brantner (water right $>110 \mathrm{ft}^{3} / \mathrm{s}$ ), Brighton (water right $>40 \mathrm{ft}^{3} / \mathrm{s}$ ), and Lupton Bottoms (water right $>150 \mathrm{ft}^{3} / \mathrm{s}$ ) (pl. 1), also may remove substantial volumes of river water during the irrigation season.

The South Platte River alluvial aquifer in the study area is a relatively narrow band of unconsolidated gravel, sand, silt, and clay that parallels the river. Mineralogically, the aquifer material is dominated by quartz and feldspar. The aquifer ranges in width from about 2 to $5 \mathrm{mi}$ (Hurr and Schneider, 1972). Depth to ground water varies from 0 to about $30 \mathrm{ft}$, and the saturated thickness varies from 10 to $40 \mathrm{ft}$ (Hurr and Schneider, 1972). Ground water generally flows in a downvalley direction, subparallel to the river. Gaggiani and others (1987) reported that the rate of incremental ground-water discharge to the South Platte River between Henderson and Fort Lupton varied from $0\left(\mathrm{ft}^{3} / \mathrm{s}\right) / \mathrm{mi}$ in March 1968 to $3.2\left(\mathrm{ft}^{3} / \mathrm{s}\right) / \mathrm{mi}$ in November 1968. 


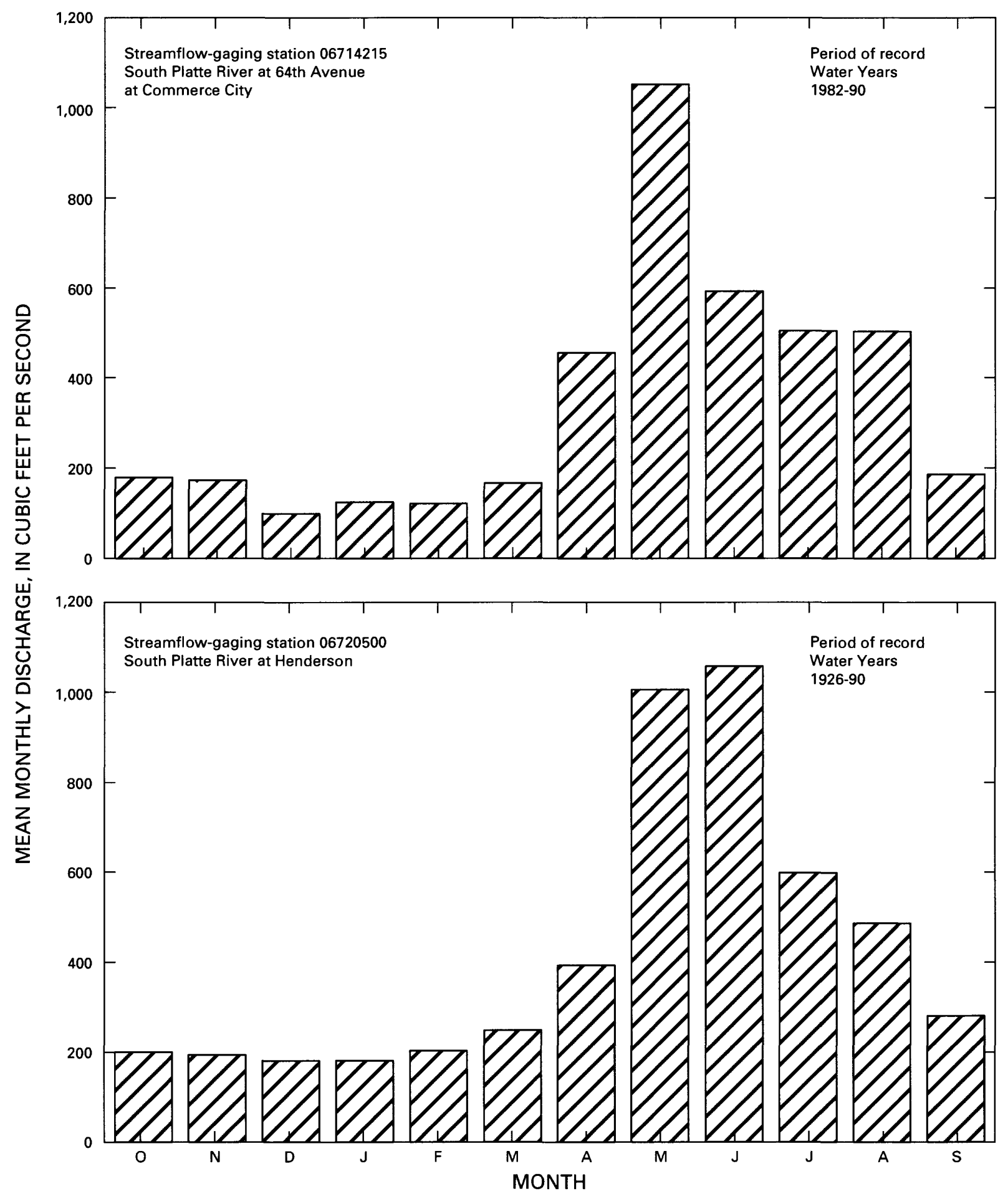

Figure 1. Mean monthly discharge at two streamflow-gaging stations on the South Platte River between Denver and Fort Lupton. 
Concentrations of DO in the South Platte River downstream from the MWRD are variable and dependent on numerous factors, including water temperature, ammonium concentrations in the river, time of day, and the relative rates of photosynthesis and respiration by the instream biological community. Concentrations of DO less than the minimum 24-hour average DO concentrations established by the Colorado Department of Health and Environment (1993) can occur during periods of low flow from about July through October (Camp Dresser and McKee, Inc., 1992). During periods of low flow, instantaneous daytime concentrations of DO in the South Platte River exhibit a cyclic pattern with distance downstream from the MWRD plant. The most important feature of the longitudinal DO profile is the presence of two reaches in which instantaneous DO concentrations are low relative to concentrations of $\mathrm{DO}$ upstream from the MWRD facility. The first reach extends from above the 88th Avenue bridge to the Fulton Ditch headgate, 3.3 to $6.4 \mathrm{mi}$ downstream from the MWRD effluent outfalls. The second reach extends from 160th Avenue to Highway 52 in Fort Lupton, 17 to $25 \mathrm{mi}$ downstream from the MWRD effluent outfalls (pl. 1).

\section{METHODS OF DATA COLLECTION}

This study used a variety of data-collection techniques to provide the information necessary to describe the quantity and quality of ground-water discharge to the South Platte River. Some of the techniques used to directly measure ground-water discharge to the river were developed specifically for this project to accommodate the physical and hydrologic conditions present in the study area.

\section{Discharge Measurements}

Fourteen sites were established to measure surface-water discharge (table 1). Six sites were located on the South Platte River, four sites were located on tributaries to the South Platte River, two sites were at irrigation ditches, and two sites were at wastewater-treatment facilities. Discharge measurements at the wastewater-treatment plants were obtained from the plant operators. The discharge-measurement sites on Sand Creek and Clear Creek were located at the gaging stations at those sites (Sand Creek at mouth near Commerce City, station number 394839104570300, and Clear Creek at Derby, station number 06720000). The measurement sites on Niver Creek and Big Dry Creek were located at the mouths of the creeks. Measurements of surfacewater discharge were made from August 1992 through January 1993 and in May and July 1993.

Surface-water discharge measurements were made using methods described by Buchanan and Somers (1969). In general, discharge was measured by dividing the stream channel into a minimum of 25 equal-width increments perpendicular to the direction of flow and measuring surface-water velocity in each increment. If the water depth was less than $2.5 \mathrm{ft}$, velocity was measured at a depth of 0.6 times the total

Table 1. Surface-water sites at which discharge was measured

\begin{tabular}{|c|c|c|}
\hline $\begin{array}{l}\text { Site } \\
\text { type }\end{array}$ & Location & $\begin{array}{l}\text { Station } \\
\text { number }\end{array}$ \\
\hline \multirow[t]{6}{*}{ South Platte River } & At 64th Avenue at Commerce City. & 06714215 \\
\hline & At 88th Avenue. & -- \\
\hline & At 104th Avenue. & -- \\
\hline & Upstream from the Brighton Ditch headgate. & -- \\
\hline & At 160 th Avenue. & -- \\
\hline & At Highway 52. & -- \\
\hline \multirow[t]{4}{*}{ Tributaries } & Sand Creek at mouth near Commerce City. & 394839104570300 \\
\hline & Clear Creek at Derby. & 06720000 \\
\hline & Niver Creek at mouth. & -- \\
\hline & Big Dry Creek at mouth. & -- \\
\hline \multirow[t]{2}{*}{ Irrigation ditches } & Brantner Ditch at headgate. & -- \\
\hline & Lupton Bottoms Ditch at headgate. & -- \\
\hline \multirow[t]{2}{*}{ Wastewater-treatment plants } & Metro Wastewater Reclamation District. & -- \\
\hline & City of Brighton. & -- \\
\hline
\end{tabular}


depth. If water depth was greater than $2.5 \mathrm{ft}$, velocity was measured at a depth of 0.2 times the total depth and at a depth of 0.8 times the total depth, and the velocities were averaged. Velocity was multiplied by the area of the increment to determine volumetric discharge (cubic feet per second) for each increment. Incremental discharges were summed to determine total surface-water discharge. Accuracy of the discharge measurements was about \pm 5 percent.

Ground-water discharge to the South Platte River was measured using indirect and direct techniques. Indirect measurements of ground-water discharge were obtained by calculating a mass balance of all measured surface-water inflows and outflows to three reaches of the river and by attributing the difference between inflows and outflows to ground-water discharge. This indirect measurement of ground-water discharge is called the incremental ground-water discharge in the following discussion. The three reaches of the South Platte River used in the mass balance extend from 64th Avenue to 88th Avenue, 104th Avenue to upstream from the Brighton Ditch headgate, and 160th Avenue to Highway 52 (pl. 1). Measurements of surface-water discharge were made at the sites listed in table 1 . In addition, the reaches were floated by boat to locate intermittent flows not identified on maps. These flows usually were from gravel-mine dewatering operations or were ungaged irrigation return flows. These measurements did not take into account surface-water losses from evapotranspiration, which is an unknown quantity for this study area. Indirect measurements of groundwater discharge were made from August 1992 through January 1993 and in May and July 1993.

River stage needs to be constant, or fluctuations in stage need to be accounted for, to use the mass-balance technique for estimating ground-water discharge. To minimize change in storage in the river, discharge measurements made on the South Platte River were timed using time-of-travel data provided by the MWRD so that measurements made at the upstream and downstream ends of the reach occurred at about the same time on the hydrograph. For example, if the upstream measurement was made at the peak of daily stage fluctuations, the downstream measurement was timed so that it also was made at the peak of daily stage fluctuations. The time lag between discharge measurements made at the upstream and downstream ends of each segment were:

(1) 3 hours between 64th Avenue and 88th Avenue;

(2) 4.5 hours between 104th Avenue and Brighton Ditch; and (3) 3.5 hours between 160th Avenue and Highway 52 (Todd Harris, Metro Wastewater Reclamation District, written commun., 1992).
Direct measurements of ground-water discharge were made from August 1992 through January 1993 at the 30 cross sections listed in table 2 using the following techniques:

1. Five piezometers were installed at each of the 30 cross sections so that one piezometer was located in the river channel $10 \mathrm{ft}$ from each bank, one piezometer was located in the middle of the channel, and one piezometer was located between each of the outside piezometers and the piezometer located in the middle of the channel. The piezometers had carbon-steel casings with 1.5 -in inside diameters and 6-in screens; the piezometers were installed so that the middle of the screen was $1 \mathrm{ft}$ below the sediment/water interface. Each piezometer was pumped at a rate of $0.25 \mathrm{gal} / \mathrm{min}$ until the discharge water was clear (usually within 5 minutes), at which time pumping was stopped and water levels allowed to equilibrate. Water levels were allowed to equilibrate for at least 15 minutes even though preliminary tests indicated that equilibration was usually achieved within 5 minutes.

Tabie 2. Location of cross-section sites at which groundwater discharge was measured

\begin{tabular}{|c|c|c|c|}
\hline $\begin{array}{l}\text { Cross- } \\
\text { section } \\
\text { number }\end{array}$ & $\begin{array}{c}\text { Distance } \\
\text { downstream } \\
\text { from the } \\
\text { Metro } \\
\text { Wastewater } \\
\text { Reclamation } \\
\text { District } \\
\text { effluent outfalls } \\
\text { (miles) }\end{array}$ & $\begin{array}{l}\text { Cross- } \\
\text { section } \\
\text { number }\end{array}$ & $\begin{array}{c}\text { Distance } \\
\text { downstream } \\
\text { from the } \\
\text { Metro } \\
\text { Wastewater } \\
\text { Reclamation } \\
\text { District } \\
\text { effluent outfalls } \\
\text { (miles) }\end{array}$ \\
\hline 1 & -0.2 & 16 & 11.7 \\
\hline 2 & 1.2 & 17 & 12.4 \\
\hline 3 & 2.1 & 18 & 13.8 \\
\hline 4 & 2.5 & 19 & 14.2 \\
\hline 5 & 2.8 & 20 & 14.8 \\
\hline 6 & 3.1 & 21 & 16.8 \\
\hline 7 & 3.4 & 22 & 18.0 \\
\hline 8 & 4.3 & 23 & 19.0 \\
\hline 9 & 4.9 & 24 & 19.9 \\
\hline 10 & 5.5 & 25 & 21.6 \\
\hline 11 & 6.7 & 26 & 22.0 \\
\hline 12 & 7.5 & 27 & 22.5 \\
\hline 13 & 8.5 & 28 & 23.1 \\
\hline 14 & 10.5 & 29 & 23.7 \\
\hline 15 & 11.1 & 30 & 24.6 \\
\hline
\end{tabular}


2. A manometer similar to that described by Winter and others (1988) was used to measure the difference in hydraulic head between ground water at a depth of $1 \mathrm{ft}$ beneath the sediment/ water interface in each piezometer and the river. The precision of the manometer readings was \pm 0.075 in. This information was used to calculate the hydraulic gradient between the ground water and surface water using equation 1:

$$
i=d h / d l
$$

where

$i$ is the hydraulic gradient, unitless;

$d h$ is the difference in hydraulic head between ground water and surface water, in inches; and

$d l$ is the distance between the ground-water and surface-water measurement points, in inches.

3. A 4-in-diameter PVC tube was installed immediately adjacent to each piezometer so that the bottom opening of the tube was at the same depth as the midpoint of the screen on the piezometer. Riverbed sediments probably were disturbed as the PVC tube was installed. The top opening of the tube extended above the river surface. This PVC tube was used in a constant-head permeameter test to measure the hydraulic conductivity of the $1-\mathrm{ft}$ cylinder of sediment across which hydraulic gradient also was measured (Bowles, 1978). The tests assumed that all of the head loss occurred in the column of sediment tested and that head losses in sediment below the permeameter were negligible. This assumption is realistic because vertical hydraulic-conductivity values in sediments usually are much lower than horizontal hydraulic-conductivity values. The permeameter test was run for 1 minute or until $1 \mathrm{~L}$ of water had passed through the sediment column, whichever came first. The test was done in triplicate and the average value of hydraulic conductivity was used in further calculations. Hydraulic conductivity was measured each time the cross sections were sampled.

4. The hydraulic-conductivity and hydraulicgradient measurements were used to calculate the specific discharge of ground water at each piezometer using equation 2 :

$$
v=-K i
$$

where

$v$ is the specific discharge of ground water, in feet per second;

$K$ is hydraulic conductivity, in feet per second; and

$i$ is hydraulic gradient, unitless.

5. Instantaneous ground-water discharge at each cross section was calculated using equation 3 :

$$
\begin{aligned}
q_{t} & =\left[\sum\left(v_{n} L_{n}\right)\right](5,280), \\
\mathrm{n} & =\text { piezometers } 1 \text { through } 5
\end{aligned}
$$

where

$q_{t}$ is instantaneous ground-water discharge for the cross section, in cubic feet per second per mile;

$v_{n}$ is the specific discharge of ground water at the $n^{\text {th }}$ piezometer, in feet per second;

$L_{n}$ is one-half the distance from the $n^{\text {th }}$ piezometer to each of the adjacent piezometers, in feet. In the case of the piezometers near the bank, $L_{n}$ is the distance between the bank and the $\mathrm{n}^{\text {th }}$ piezometer plus one-half the distance from the $n^{\text {th }}$ piezometer to the next adjacent piezometer, and 5,280 is the number of feet per mile.

Note that the specific discharge calculated using equation 2 expresses an average rate of flow rather than the velocity of individual particles of water; therefore, the use of specific discharge in equation 3 allows for the calculation of an average instantaneous ground-water discharge rate. This rate will be referred to as the instantaneous ground-water discharge rate in the discussion to follow.

Temporal variations in instantaneous groundwater discharge across the sediment/water interface were measured at the McKay Road, Henderson, and Road 8 cross-section sites using this technique by taking measurements hourly for 24 hours.

\section{Continuous River-Stage and Ground-Water- Level Measurements}

Continuous measurements of river stage and ground-water levels were made at the Henderson and Road 8 sites. River-stage measurements at the Henderson site were obtained from the longterm streamflow-gaging station at that site (station number 06720500) (pl. 1). River-stage measurements at the Road 8 site were obtained from a stilling well using an automatic data recorder connected to a paper- 
punch recorder. Ground-water levels were measured in the water-table wells on the east side of the river at each site (wells Henderson $1 \mathrm{~A}$ and Road 8 1A). The watertable wells were instrumented with a water-level potentiometer connected to an electronic data logger so that changes in ground-water levels could be recorded. All measurements were recorded every 15 minutes. The gaging station and water-table well at each site were surveyed to an arbitrary local datum so that river stage and ground-water levels could be directly compared.

\section{Water-Quality Sampling}

Grab samples of surface water were collected from the McKay Road, Henderson, and Road 8 sites and analyzed for field properties, major ions, nutrients, iron, and manganese (pl. 1). Field properties were measured at the time of sample collection and included specific conductance, $\mathrm{pH}$, water temperature $(\mathrm{T}), \mathrm{DO}$, and alkalinity. Major ions included calcium, magnesium, sodium, potassium, sulfate, and chloride. Nutrient species included nitrite, nitrite plus nitrate, ammonium, ammonium plus organic nitrogen (all as nitrogen), phosphorus, and orthophosphate (all as phosphorus). Grab samples of surface water were collected next to temporary nested piezometers (discussed later in this section) so that comparisons could be made between surface-water and ground-water chemistry. Samples were collected from August 1992 through January 1993 and in May and July 1993.

The specific conductance, $\mathrm{pH}, \mathrm{T}$, and $\mathrm{DO}$ of surface water also were measured at each of the 30 crosssection sites (pl. 1). Measurements were made in the middle of the channel. Measurements were made from August 1992 through January 1993.

All field measurements in surface water, excluding alkalinity, were made using portable meters with the electrode suspended directly in the river. Measurements of alkalinity were made by incremental titration of a $50-\mathrm{mL}$ sample of filtered water using 1.6 Normal sulfuric acid. Prior to making a measurement, each meter and electrode were calibrated using standards obtained from the USGS Water-Quality Service Unit in Ocala, Florida. The conductivity electrode and meter were calibrated daily using conductivity standards that bracketed the expected range of conductivity values to be measured. The $\mathrm{pH}$ electrode and meter were calibrated daily using $\mathrm{pH} 7$ and 10 buffers. The DO electrode was calibrated daily in water-saturated air, and measurements were compared to theoretical values for the given water temperature and atmospheric pressure to check the high-concentration range of the DO electrode and meter. The low-concentration range of the
DO electrode and meter was checked weekly using a zero-DO solution. The performance of the DO electrode and meter also was checked weekly against modified Winkler DO titrations of replicate water samples.

Surface-water samples collected for major-ion and nutrient analyses were filtered $(0.45-\mu \mathrm{m}$ pore size, 5.6-in-diameter membrane filter) immediately after collection, preserved if needed, and stored on ice until delivery to the laboratory at the end of the day. Samples were filtered by pumping the sample with a peristaltic pump through the filtration device (acrylic filter assembly). Samples analyzed for dissolved calcium, magnesium, sodium, potassium, iron, and manganese were preserved with nitric acid. Samples analyzed for dissolved nitrite, nitrite plus nitrate, ammonium, . and ammonium plus organic nitrogen were preserved with sulfuric acid. No preservative was added to samples analyzed for dissolved sulfate, chloride, phosphorus, and orthophosphate. Chemical analyses were performed by the MWRD laboratory following established U.S. Environmental Protection Agency guidelines. Analytical results for nitrogen-bearing nutrient species and phosphorus-bearing nutrient species were reported in milligrams per liter as nitrogen and in milligrams per liter as phosphorus, respectively.

Samples of ground water in the alluvial aquifer were collected from twelve 2-in-diameter PVC monitoring wells located adjacent to the South Platte River (pl. 1). Samples were collected from August 1992 through January 1993 and in May and July 1993. Samples were analyzed for specific conductance, $\mathrm{pH}, \mathrm{T}$, DO, alkalinity, major ions, nutrients, iron, and manganese. Four wells were installed at each of three locations near: (1) McKay Road, $5.8 \mathrm{mi}$ downstream from the MWRD plant; (2) Henderson, 11.1 mi downstream from the MWRD plant; and (3) Road 8, 22.1 mi downstream from the MWRD plant. The three locations were selected so that ground water could be sampled adjacent to the two segments of river in which DO sags occur (McKay Road and Road 8) and adjacent to a segment of the river in which DO concentrations recover (Henderson). Two wells were installed near the right bank of the river (wells designated $1 \mathrm{~A}$ and $1 \mathrm{~B}$ ), and two wells were installed near the left bank of the river (wells designated 2A and 2B) at each of the three locations. Each pair of wells consisted of a shallow well screened near the water table (wells designated A) and a deep well screened at the base of the alluvial aquifer (wells designated B). The wells were located about 15 to $100 \mathrm{ft}$ from the bank of the river. Construction details for the monitoring wells are listed in table 3. 
Table 3. Construction details for monitoring wells at the McKay Road, Henderson, and Road 8 sites

\begin{tabular}{llccc}
\hline Well & $\begin{array}{c}\text { Total depth below } \\
\text { land surface } \\
\text { (feet) }\end{array}$ & $\begin{array}{c}\text { Depth below } \\
\text { land surface } \\
\text { to top of } \\
\text { screened interval } \\
\text { (feet) }\end{array}$ & $\begin{array}{c}\text { Depth below } \\
\text { land surface } \\
\text { to bottom of } \\
\text { screened interval } \\
\text { (feet) }\end{array}$ & $\begin{array}{c}\text { Location } \\
\text { relative to } \\
\text { river channel }\end{array}$ \\
\hline McKay Road 1A & 14.5 & 9 & 14 & 29 \\
McKay Road 1B & 30 & 24 & 10 & Right bank. \\
McKay Road 2A & 10.5 & 5 & 28 & Left bank. \\
McKay Road 2B & 29 & 23 & 27.2 & Left bank. \\
Henderson 1A & 27.8 & 17.2 & 31 & Right bank. \\
Henderson 1B & 34 & 29 & 10 & Right bank. \\
Henderson 2A & 11 & 5 & 25 & Left bank. \\
Henderson 2B & 30 & 20 & 12.5 & Left bank. \\
Road 8 1A & 13 & 7.5 & 30.5 & Right bank. \\
Road 8 1B & 32 & 25.5 & 13 & Right bank. \\
Road 8 2A & 13.5 & 8 & 33 & Left bank. \\
Road 8 2B & 34 & 28 & Left bank. \\
\hline
\end{tabular}

Ground-water samples were collected from the monitoring wells using a submersible pump. Prior to sample collection, the well was purged of three casing volumes of water. After three casing volumes of water were removed from the well, pumped water was routed through an enclosed chamber in which specific conductance, $\mathrm{pH}, \mathrm{T}$, and $\mathrm{DO}$ electrodes were placed. Water was passed through this chamber, and field properties were measured until they stabilized (typically 15 to 20 minutes). After stabilization was reached, the pump-discharge line was attached to a filtration device, and water samples were filtered, preserved, and chilled using the same procedure as described previously in this section. Alkalinity titrations were performed on filtered samples. Samples were analyzed by the MWRD laboratory.

Ground-water samples were collected from the 30 cross-section sites using a peristaltic pump and the five piezometers installed $1 \mathrm{ft}$ below the sediment/water interface. Piezometer installation at the cross-section sites was described in the "Discharge Measurements" section. Measurements were made from August 1992 through January 1993. Samples were analyzed for specific conductance, $\mathrm{pH}$, $\mathrm{T}$, DO, and nutrients. Field properties were measured at each piezometer by pumping water from the piezometer to the bottom of a plastic beaker in which specific conductance, $\mathrm{pH}, \mathrm{T}$, and $\mathrm{DO}$ electrodes were placed. Water was allowed to bottom fill the beaker and overflow as measurements were taken. This process continued until the field properties stabilized (10 to 15 minutes). After field properties had stabilized, a 1-L sample of water was collected in a plastic bottle. This procedure was repeated at each of the five piezom- eters. Water samples from each of the piezometers were composited using a weighting factor for the discharge velocity of ground water measured at the piezometers so that more water was added to the composite from piezometers that had high discharge velocities than from piezometers that had low discharge velocities. No water was added to the composite from piezometers where the direction of groundwater movement was from the river to the sediment. The procedure described in this paragraph produced a single, discharge-velocity-weighted water sample for each cross section. Once the composite sample was obtained, it was filtered, and samples were prepared and preserved using the techniques described previously in this section for nutrient samples. The values of specific conductance, $\mathrm{pH}, \mathrm{T}$, and $\mathrm{DO}$ reported for each cross section were discharge-velocityweighted values using measurements made at the five piezometers.

Temporary nested piezometers also were installed at depths of 3 to 12,30 to 48 , and 80 to 84 in. below the sediment/water interface in the river channel to measure the variability in ground-water quality with depth at the McKay Road, Henderson, and Road 8 monitoring-well sites (pl. 1). Samples were collected from August 1992 through January 1993 and in May and July 1993. Samples were analyzed for specific conductance, $\mathrm{pH}, \mathrm{T}, \mathrm{DO}$, alkalinity, major ions, nutrients, iron, and manganese. The three piezometers were located within 6 in. of each other, and they were constructed of the same materials as those used at the 30 cross-section sites, except for the piezometer used to collect the 80- to 84-in-deep sample, which was made of 0.5 -in inside-diameter aluminum-alloy conduit. The vertical-profile samples were collected about $1 \mathrm{ft}$ into the river channel near the left bank at each site. Excep- 
tions were the vertical-profile samples collected from the Road 8 site in October 1992 (samples were collected from below the middle of the channel) and November 1992 (samples were collected from below the channel near the right bank). The locations of the vertical-profile sampling sites at Road 8 were varied to examine vertical profiles of water quality at different locations in the channel.

Selected samples of filtered surface water and ground water and riverbed sediment were sent to the USGS National Water-Quality Laboratory in Arvada, Colorado, for analysis of the ${ }^{15} \mathrm{~N} /{ }^{14} \mathrm{~N}$ ratios of nitrate and ammonium in the samples. Unfiltered samples of surface water and ground water were collected for the analysis of total organic carbon once during the study. Samples were analyzed by the USGS National WaterQuality Laboratory in Arvada, Colorado, using established analytical procedures (Wershaw and others, 1987).

Samples of surface water and ground water were collected for quality-assurance assessment. Qualityassurance samples consisted of replicates, equipment blanks, and splits. Replicates consisted of sequential samples for each type of analysis and were used to monitor the precision of the laboratory analytical methods. Equipment blanks consisted of distilled-water samples that were processed through the sampling equipment, after the equipment had been washed, in the same order as environmental samples, and were used to monitor the potential for cross contamination of samples between sampling sites. Equipment-blank and replicate samples usually were collected each week that the cross-section sites were sampled, and they were collected each month that the monitoring wells were sampled. Selected samples also were split and sent to the MWRD laboratory and the USGS National Water-Quality Laboratory in Arvada, Colorado, for analysis of the same constituents so that the analytical performance of the laboratories could be compared.

\section{Sediment Sampling}

Riverbed and aquifer sediments were collected one time for analyses of percent sediment (by weight) that was less than 0.079 in. in size, percent organic matter (by weight) in the less than 0.079-in size fraction, and rates of microbial denitrification. Riverbed sediment was collected from three locations in the river channel at each of two sites (Henderson and Road 8). These locations included the right edge of water, center of the channel, and left edge of water. Riverbed sediment was collected at the right edge of water and center of the channel at the McKay Road site. Riverbed sediment also was collected at the left edge of water at 88th Avenue for microbiological analyses, but not for grain-size or organic-carbon analysis. Aquifer sediment was collected during installation of monitoring wells 2B at McKay Road, 2B at Henderson, and $1 B$ at Road 8 (pl. 1).

Samples of riverbed sediment used for grain-size and organic-matter measurements were collected using PVC tubes hammered into the sediment to a depth of 0 to $2 \mathrm{ft}$ and withdrawn by hand to retrieve the sediment. Grain size was determined by drying the sediment at $105^{\circ} \mathrm{C}$ for 48 hours and passing the sediment through a 0.079 -in sieve. The sieved material was weighed and divided by the weight of the starting material to determine the percent of sediment (by weight) that was sand, silt, or clay sized. Organic-matter content of the less than 0.079 -in size fraction was determined by weighing the sediment before and after combustion at $650^{\circ} \mathrm{C}$ for 12 hours and attributing the change in mass to organic material. Riverbed sediment used for microbiological analysis was collected using the same procedure, except that PVC tubes were methanol-rinsed prior to use. The samples were placed in sterilized glass jars and shipped to the USGS South Carolina District for measurement of denitrification rates using the acetylene-block technique (Bradley and others, 1992). Preliminary experiments were done with no additions of nitrate and organic carbon to estimate rates of denitrification under in-situ conditions. Additional experiments were performed to determine if denitrification rates were limited by the availability of nitrate or organic carbon by adding nitrate and glucose to the sediments and repeating the experiments. Incubations were done in triplicate with killed (autoclaved) controls to account for abiotic production of nitrous oxide $\left(\mathrm{N}_{2} \mathrm{O}\right)$ by the sediment.

Samples of aquifer sediment used for grain-size and organic-matter content were collected from the alluvial aquifer at the time that the PVC monitoring wells were installed. Sediment samples were collected at the locations of monitoring wells McKay Road 2B, Henderson 2B, and Road $81 \mathrm{~A}$. Sediment at these sites was collected every $5 \mathrm{ft}$ starting at land surface and ending at the base of the alluvium. Because of the lack of cohesion of the sediments, samples were not collected using standard coring devices such as the split spoon or Shelby tube. Instead, sediment was collected directly from the auger flights as they were brought to land surface. These samples were analyzed for grainsize and organic-matter content using procedures described in the previous paragraph. Samples of aquifer sediment for microbiological analysis were collected from the water table in a hand-dug hole near well $2 \mathrm{~A}$ at the Henderson site. Sediment was collected using an alcohol-cleaned PVC tube that was pushed into the sediment. 


\section{QUANTITY OF GROUND-WATER DISCHARGE}

The discussion on the quantity of ground-water discharge to the South Platte River between Denver and Fort Lupton is divided into two subsections: the quantity of ground-water discharge from the largearea flow system and the quantity of ground-water discharge from the small-area flow system. The precise boundaries of the two flow systems are not known. However, the large-area flow system was considered to incorporate all alluvial sediments in hydrologic connection with the South Platte River (Hurr and Schneider, 1972). The small-area flow system was considered to incorporate the alluvial aquifer in the vicinity of the river. Flow-path lengths in the largearea system were considered to be on the order of hundreds of feet to more than a mile, whereas flow-path lengths in the small-area system were considered to be on the order of feet to hundreds of feet. The small-area flow system is superimposed on the large-area system.

\section{Large-Area Flow System}

The quantity of ground-water discharge from the large-area flow system to the South Platte River was estimated by calculating a mass balance of all measured surface-water inflows and outflows to the three reaches of the river and by attributing the difference between inflows and outflows to groundwater discharge (table 4). This discharge is referred to as the incremental ground-water discharge in the discussion to follow. Surface-water discharge measurements used in the mass-balance calculations are listed in table 8 in the "Hydrologic and WaterQuality Data" section. Mass-balance estimates of incremental ground-water discharge ranged from -27 to $17\left(\mathrm{ft}^{3} / \mathrm{s}\right) / \mathrm{mi}$ for the three reaches studied (table 4); the median rate was $4.6\left(\mathrm{ft}^{3} / \mathrm{s}\right) / \mathrm{mi}$. Incremental ground-water discharge rates determined by mass balance were most variable in reach 1 extending from 64th to 88th Avenue and were partially related to the amount of effluent being released from the MWRD (tables 4 and 8). There generally was a net addition of water to the river from ground-water discharge when the rate of effluent discharge from MWRD was relatively low (for example, September, November, and December 1992 and July 1993), whereas there was a net loss of water from the river to the aquifer when the rate of effluent discharge was relatively high (for example, August 1992 and January 1993) or when flow in the river upstream from the plant was relatively high (for examplc, May 1993). The total ground-water discharge in reach 1 on August 28, 1992, was about the same magnitude as the accuracy of surface-water discharge measurements. It is not certain, therefore, that reach 1 was losing water to the aquifer on that date. The effect of high flows from the MWRD on the amount of ground-water discharge to reach 1 was to decrease ground-water inflows, and the effect probably was a daily occurrence based on the record of large daily fluctuations in discharge from the MWRD plant (fig. 2).

There was less variability in the incremental ground-water discharge rates determined by mass balance in reaches of the river downstream from 88th Avenue than there was in the reach upstream from 88th Avenue (table 4), possibly due to increased irrigation return flows from agricultural fields overlying the alluvial aquifer downstream from Denver and to a dampening of discharge fluctuations with distance downstream from the MWRD plant. Median rates of incremental ground-water discharge in the reaches extending from 104th Avenue to upstream from the Brighton Ditch headgate and from 160th Avenue to Highway 52 were within about 10 percent of each other [5.1 and $4.6\left(\mathrm{ft}^{3} / \mathrm{s}\right) / \mathrm{mi}$. The median percentage of flow in the river at the downstream end of each reach from ground-water discharge was 17 percent for reach 2 extending from 104th Avenue to Brighton Ditch Diversion and 11 percent for reach 3 extending from 160th Avenue to Highway 52. The median percentage for these two reaches combined was 15 percent. The median percentage of surface-water discharge derived from ground-water discharge for all three reaches was 13 percent. Based on these estimates, ground-water discharge between 104th Avenue and Highway 52 would have accounted for a total of about 30 percent of the flow in the river at Highway 52. Note that the highest rate of incremental ground-water discharge measured between 160th Avenue and Highway 52, $16\left(\mathrm{ft}^{3} / \mathrm{s}\right) / \mathrm{mi}$, occurred on August 27, 1992 (table 4), about 4 days after a large rainstorm that increased river stage by about $3 \mathrm{ft}$ at the Henderson gaging station. This high rate of ground-water discharge probably resulted from the return of storm-derived bank-storage water to the river. The net inflow of ground water to the river downstream from 88 th Avenue is consistent with continuous water-level measurements made in watertable wells adjacent to the river at the Henderson and Road 8 sites (fig. 3). At these two sites, ground-water levels were higher than river stage during the period of record, indicating that ground water was discharging to the river rather than surface water infiltrating into the large-area flow system, regardless of the daily variations in discharge from the MWRD plant (fig. 2). 
Table 4. Water balance for selected reaches of the South Platte River on selected dates

[ $\mathrm{ft}^{3} / \mathrm{s}$. cubic foot per second: $\left(\mathrm{ft}^{3} / \mathrm{s}\right) / \mathrm{mi}$, cubic foot per second per mile]

\begin{tabular}{|c|c|c|c|c|c|c|}
\hline \multirow[b]{2}{*}{ Reach } & \multirow[b]{2}{*}{ Date } & \multicolumn{2}{|c|}{ Surface water } & \multicolumn{3}{|c|}{ Ground water } \\
\hline & & $\begin{array}{c}\text { Total } \\
\text { inflow } \\
\left(\mathrm{ft}^{3} / \mathbf{s}\right)\end{array}$ & $\begin{array}{c}\text { Total } \\
\text { outfiow } \\
\left(\mathrm{ft}^{3} / \mathrm{s}\right)\end{array}$ & $\begin{array}{c}\text { Total } \\
\text { specific } \\
\text { discharge } \\
\left(\mathrm{f}^{3} / \mathrm{s}\right)\end{array}$ & $\begin{array}{l}\text { Incremental } \\
\text { specific } \\
\text { dlscharge } \\
{\left[\left(\mathrm{ft}^{3} / \mathrm{s}\right) / \mathrm{ml}\right]}\end{array}$ & $\begin{array}{l}\text { Percent of } \\
\text { surface-water } \\
\text { outflow }\end{array}$ \\
\hline \multirow[t]{7}{*}{${ }^{2} 1$} & $08 / 28 / 92$ & 389 & 380 & -9.0 & -2.5 & 0 \\
\hline & $09 / 23 / 92$ & 240 & 318 & 78 & 17 & 24 \\
\hline & $11 / 02 / 92$ & 207 & 259 & 52 & 15 & 20 \\
\hline & $12 / 02 / 92$ & 143 & 154 & 11 & 3.1 & 7.0 \\
\hline & $01 / 19 / 93$ & 340 & 245 & -95 & -27 & 0 \\
\hline & $05 / 19 / 93$ & 798 & 710 & -88 & -25 & 0 \\
\hline & $07 / 27 / 93$ & 355 & 405 & 50 & 14 & 12 \\
\hline \multirow[t]{6}{*}{$b_{2}$} & $09 / 28 / 92$ & 127 & 165 & 38 & 4.5 & 27 \\
\hline & $10 / 30 / 92$ & 157 & 181 & 24 & 2.8 & 13 \\
\hline & $12 / 01 / 92$ & 212 & 273 & 61 & 7.3 & 22 \\
\hline & $01 / 15 / 93$ & 192 & 226 & 34 & 4.0 & 15 \\
\hline & $05 / 17 / 93$ & 366 & 414 & 48 & 5.7 & 13 \\
\hline & $07 / 28 / 93$ & 315 & 379 & 64 & 7.6 & 19 \\
\hline \multirow[t]{7}{*}{$c_{3}$} & $08 / 27 / 92$ & 480 & 605 & 125 & 16 & 21 \\
\hline & $09 / 24 / 92$ & 228 & 265 & 37 & 4.6 & 16 \\
\hline & $10 / 29 / 92$ & 243 & 285 & 42 & 5.2 & 15 \\
\hline & $11 / 30 / 92$ & 354 & 399 & 45 & 5.6 & 11 \\
\hline & $01 / 14 / 93$ & 237 & 257 & 20 & 2.5 & 8.0 \\
\hline & $05 / 25 / 93$ & 361 & 372 & 11 & 1.4 & 3.0 \\
\hline & $07 / 29 / 93$ & 364 & 382 & 18 & 2.2 & 6.0 \\
\hline
\end{tabular}

${ }^{a}$ Reach 1 extended 3.54 miles from the South Platte River at 64th Avenue to the South Platte River at 88th Avenue, except for the 09/23/92 measurement, which extended 4.6 miles from the South Platte River at 64th Avenue to the South Platte River at McKay Road.

${ }^{b}$ Reach 2 extended 8.4 miles from the South Platte River at 104th Avenue to the South Platte River upstream from the Brighton Ditch headgate.

${ }^{\mathrm{c}}$ Reach 3 extended 8.01 miles from the South Platte River at 160th Avenue to the South Platte River at Highway 52.

\section{Small-Area Flow System}

The quantity of ground-water discharge from the small-area flow system to the South Platte River was estimated from direct measurements of instantaneous ground-water discharge made at the 30 crosssection sites. Instantaneous ground-water discharge from the small-area flow system ranged from $-1,360$ to $1,000\left(\mathrm{ft}^{3} / \mathrm{s}\right) / \mathrm{mi}$, with a median value of $-5.8\left(\mathrm{ft}^{3} / \mathrm{s}\right) / \mathrm{mi}$ at the 30 cross-section sites (fig. 4 and table 9). The maximum ground-water discharge rates measured for the small-area flow system are 50 to 60 times higher than previously estimated ground-water discharge rates for this reach of the South Platte River (Gaggiani and others, 1987) and are higher by a similar magnitude than maximum incremental ground-water discharge rates measured by mass balance in this study (table 4). Furthermore, measurements of the large-area flow system indicated that ground water continuously discharged to reaches 2 and 3 (table 4 and fig. 3), whereas measurements of the small-area flow system indicated that surface water recharged the aquifer as frequently as ground water discharged to the river (fig. 4). The reversals in flow direction and the high rates of instantaneous ground-water discharge from the small-area flow system are plausible if they reflect transient conditions in a small volume of the flow system. Measurements of river stage and discharge from the MWRD plant indicate that changes in river stage were related to hourly changes in effluentdischarge rates from the MWRD plant (fig. 2). These frequent changes in river stage, although typically less than about $0.25 \mathrm{ft}$, may have provided a stress on the small-area flow system large enough to cause the transient discharge conditions that were measured at the sediment/water interface. 

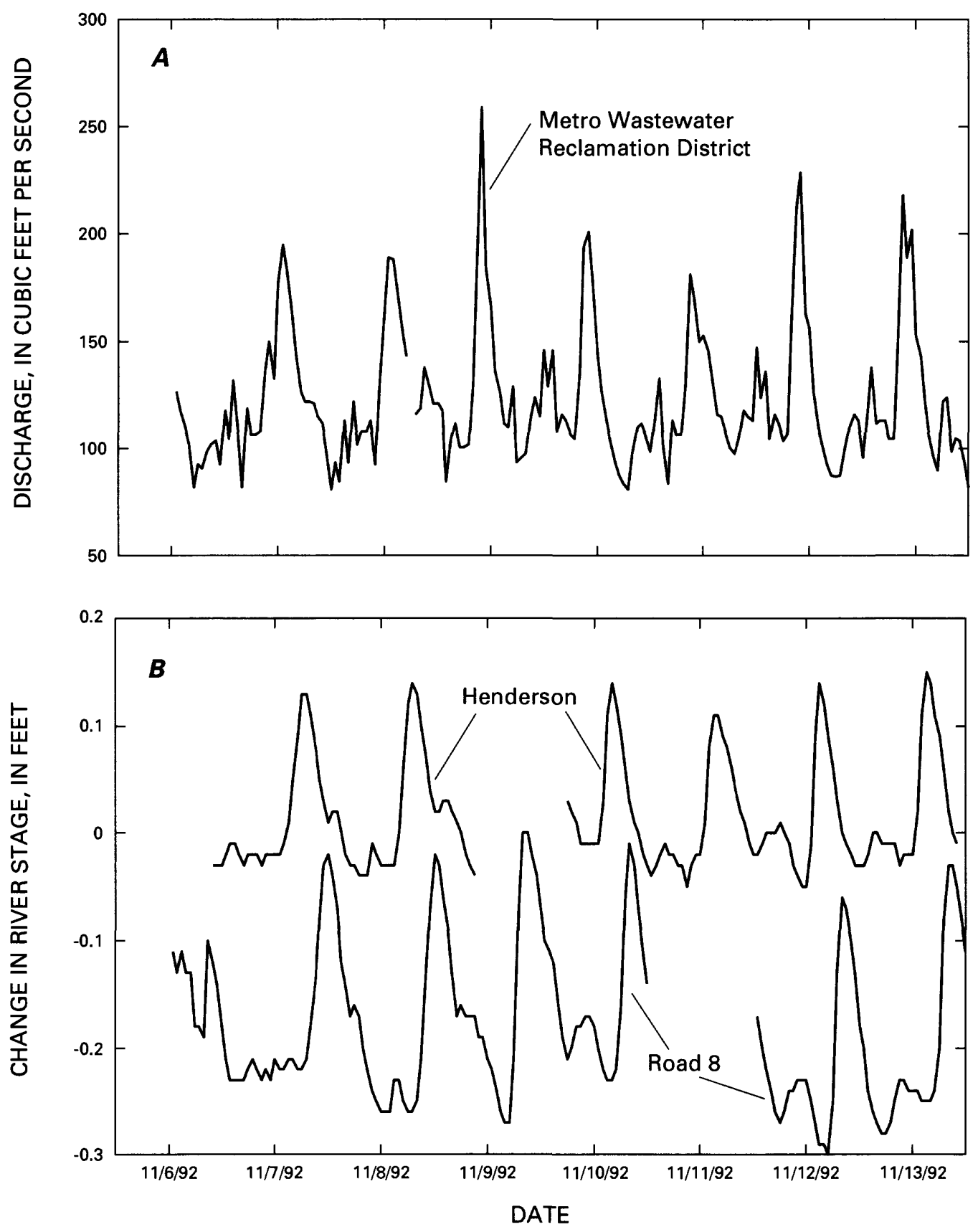

Figure 2. (A) Daily fluctuations in discharge from the Metro Wastewater Reclamation District effluent outfalls, and (B) daily changes in river stage at Henderson and Road 8. 


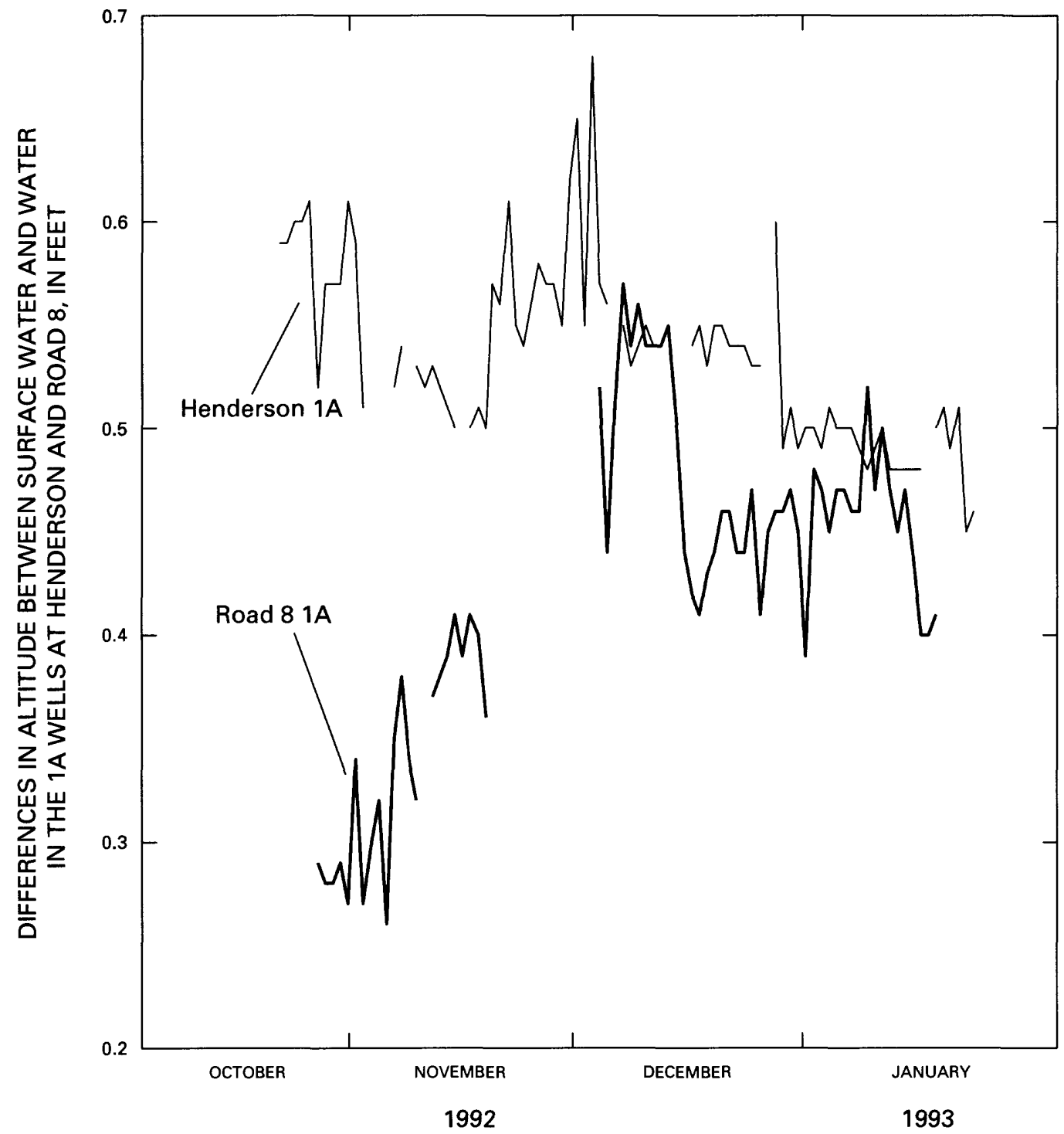

Flgure 3. Difference in altitude between surface water and water in the $1 \mathrm{~A}$ wells at Henderson and Road 8. Positive values indicate that the water level in the well was higher than the stage in the adjacent river.

The transient nature of instantaneous groundwater discharge rates in the small-area flow system were analyzed in a series of hourly measurements of discharge at the McKay Road, Henderson, and Road 8 sites (fig. 5). At each site, low-flow conditions existed during the measurement periods; therefore, the observed changes in river stage were related to variations in the MWRD effluent-discharge rates (fig. 2). Instantaneous ground-water discharge rates varied during the measurement period. The rate and direction of water movement from the small-area flow system at the McKay Road and Road 8 sites were related to changes in river stage. At both of those sites, the highest rates of ground-water discharge corresponded to the lowest river stages, whereas the lowest rates of discharge generally occurred at higher river stages. Ground-water discharge data from the Henderson site were quite different from data from the other two sites in that values of discharge at the Henderson site were negative during the entire period of record, and the least negative discharge rates generally corresponded to the highest river stages. The overlap between high river stage and the high (relative) discharge rate at the Henderson site may indicate a delayed response by hydraulic heads in the bed sediments to changes in river stage, causing a fortuitous overlap of the peaks; however, the data are insufficient to fully assess this possibility. The continuously negative rates of ground-water discharge at Henderson may indicate induced infiltration of surface water by gravel-mine dewatering operations on the west side of the river. 

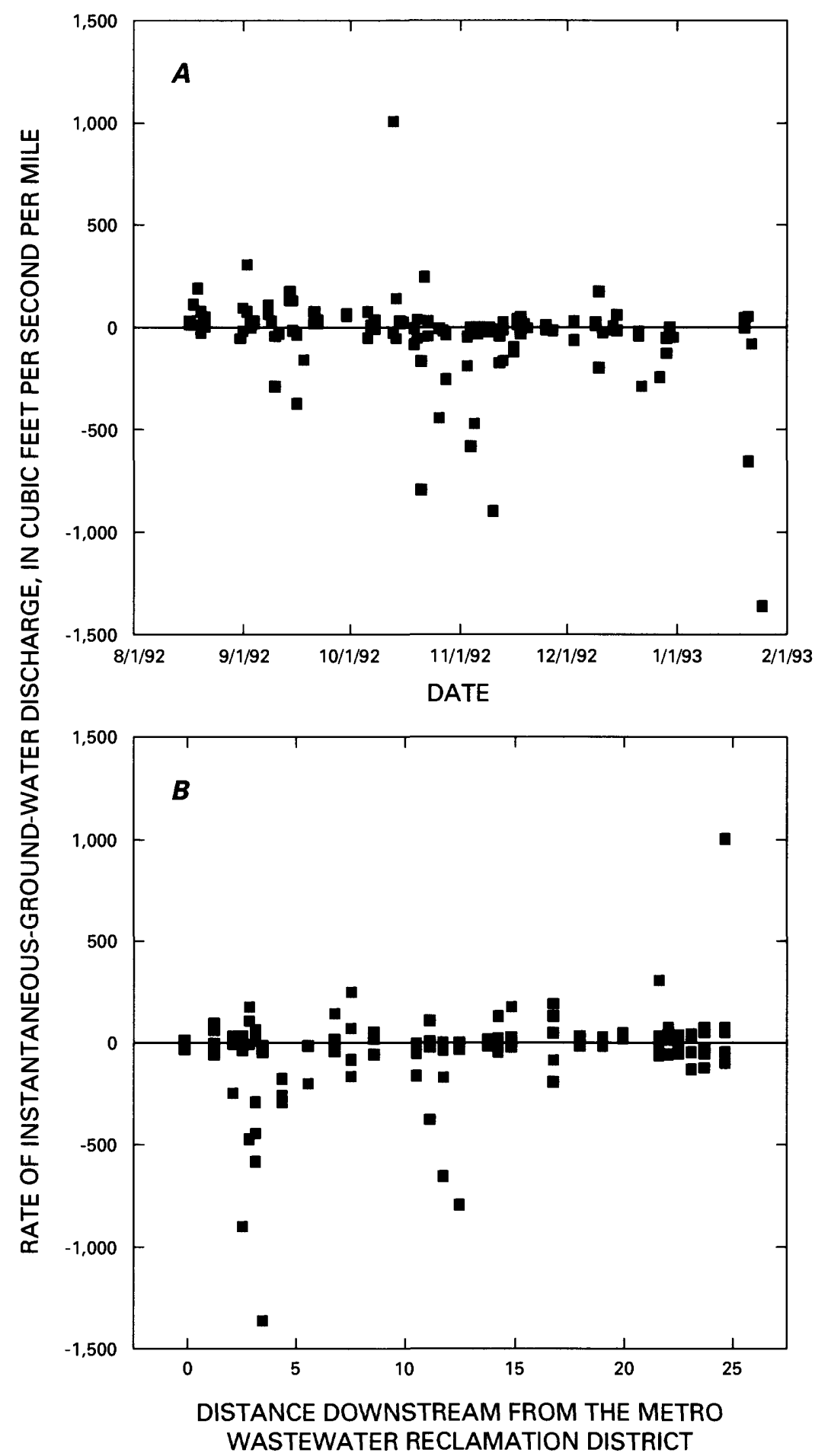

EFFLUENT OUTFALLS, IN MILES

Figure 4. Rate of instantaneous ground-water discharge across the sediment/water interface with (A) time, and (B) distance downstream from the Metro Wastewater Reclamation District effluent outfalls. Positive values indicate that ground water was discharging to the river, and negative values indicate that surface water was moving into the underlying riverbed sediments. 


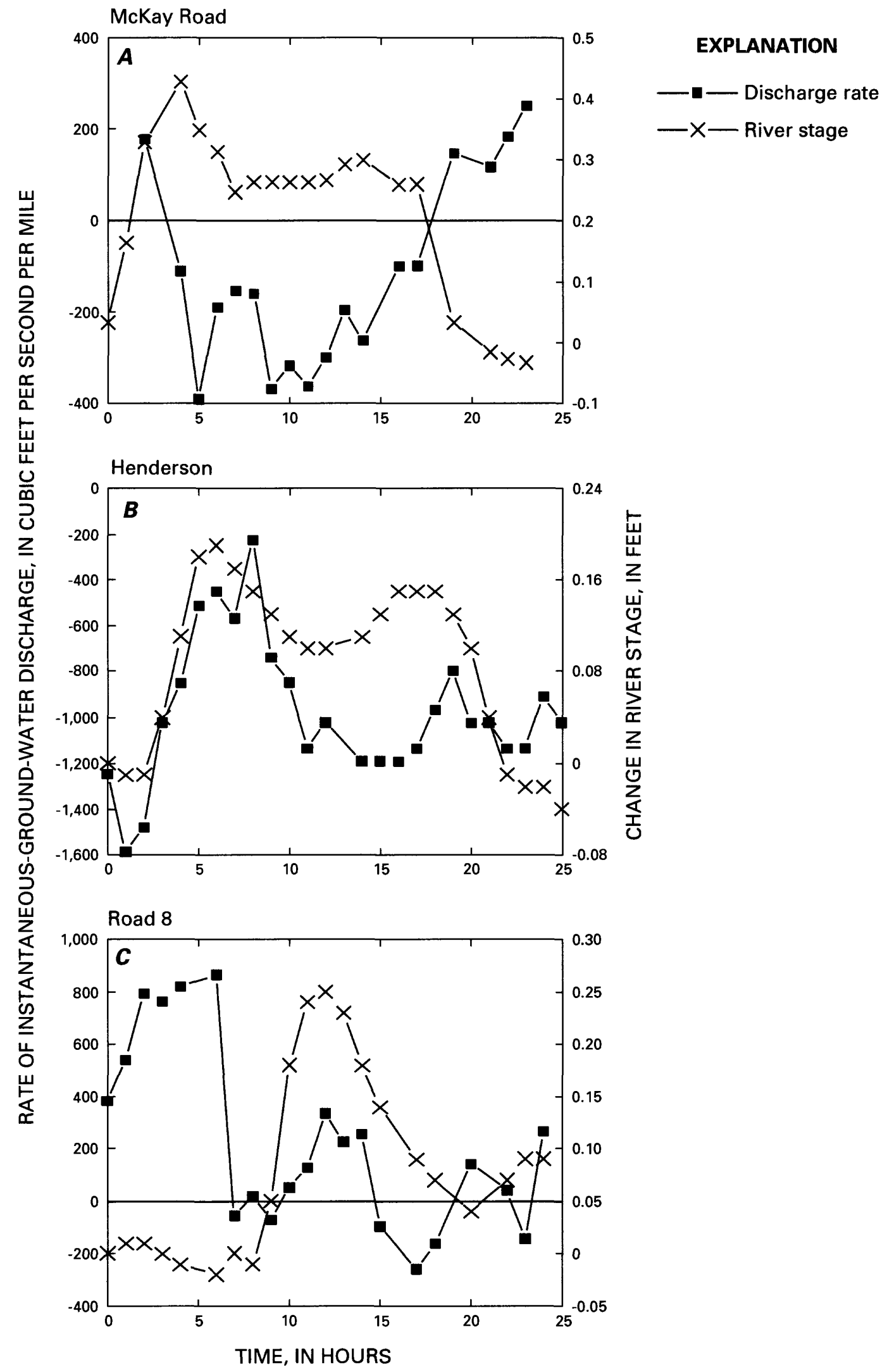

Figure 5. Rate of instantaneous ground-water discharge across the sediment/water interface with time in the South Platte River at (A) McKay Road on January 24 and 25, 1993; (B) Henderson on January 26 and 27, 1993; and (C) Road 8 on November 18 and 19, 1992. Positive values indicate discharge of ground water to the river, and negative values indicate movement of surface water into the underlying riverbed sediments. Starting times for the measurements were 0900 on January 24, 1993, at McKay Road, 1000 on January 26, 1993, at Henderson, and 0900 on November 18, 1992, at Road 8. 
Based on water-balance considerations and the cyclic nature of daily changes in discharge at the sediment/water interface (fig. 5), the small-area flow system probably did not provide a net addition or loss of water to the river. For example, integration of the discharge-rate data at the Road 8 site over 24 hours results in an estimate of instantaneous ground-water discharge from the small-area flow system to the river of about $1.49\left(\mathrm{Mft}^{3} / \mathrm{d}\right) / \mathrm{mi}$. Based on the November 30, 1992, mass-balance measurement of incremental ground-water discharge from the largearea flow system to the reach of river encompassing the Road 8 site (the closest mass-balance measurement in space and time to the 24-hour measurement), incremental ground-water discharge was about $0.48\left(\mathrm{Mft}^{3} / \mathrm{d}\right) / \mathrm{mi}$. Considering the time difference between the two sets of measurements and other possible sources of error, the estimates of ground-water discharge are very similar. The data indicate, therefore, that the small-area flow system probably provided no net gain or loss of water to the river, but that it was superimposed on the large-area flow system that did provide water to the river [at a median rate of $\left.4.6\left(\mathrm{ft}^{3} / \mathrm{s}\right) / \mathrm{mi}\right]$. In essence, the small-area flow system represented a zone of mixing between the river and the large-area flow system. White (1993) has labeled this mixing zone between surface and ground water as the hyporheic zone. The short-term movement of water to and from the small-area flow system, with no net change in the amount of water in the river, explains why measurements of ground-water discharge at the sediment/water interface indicated high rates of water movement into the aquifer even though water-table altitudes in wells adjacent to the river were always higher than the river stage. It also explains why the median value $\left[-5.8\left(\mathrm{ft}^{3} / \mathrm{s}\right) / \mathrm{mi}\right]$ of incremental discharge from the small-area flow system was relatively close to zero even though the magnitude of the minimum $\left[-1,360\left(\mathrm{ft}^{3} / \mathrm{s}\right) / \mathrm{mi}\right]$ and maximum $\left[1,000\left(\mathrm{ft}^{3} / \mathrm{s}\right) / \mathrm{mi}\right]$ measured values were large (fig. 4 and table 9 ).

\section{QUALITY OF GROUND-WATER DISCHARGE}

The discussion on the quality of ground-water discharge to the South Platte River between Denver and Fort Lupton will focus on $\mathrm{pH}$, dissolved oxygen, dissolved-nitrogen species, and dissolved-phosphorus species because they are critical water-quality issues in the study area (Camp Dresser and McKee, Inc., 1992). Other water-quality data are reported in tables 9 and 10 in the "Hydrologic and Water-Quality Data" section at the back of this report. Quality-control data were collected in the field and also are reported in the "Hydrologic and Water-Quality Data" section in table 11. The "Quality of Ground-Water Discharge" section contains two subsections: the "Large-Area Flow System" and the "Small-Area Flow System."
Water from the monitoring wells screened in the alluvial aquifer adjacent to the South Platte River was assumed to be representative of water from the largearea flow system, and water from piezometers screened below the sediment/water interface was assumed to be representative of water from the small-area flow system. However, the degree to which these assumptions are true depended on the spatial extent of mixing between the two flow systems, which was not fully defined in this study.

\section{Large-Area Flow System}

Values of $\mathrm{pH}$ in water from the monitoring wells screened in the alluvial aquifer adjacent to the river ranged from 6.63 to 7.89 , with a median value of 7.16 (fig. 6 and table 10). There was no apparent relation between $\mathrm{pH}$ and the screened-interval depth of the 12 monitoring wells. Nor was there a relation between $\mathrm{pH}$ and whether the well was located on the east side of the river or the west side of the river. Values of $\mathrm{pH}$ in water from the monitoring wells generally were lower than values in the river (fig. 7 and table 10). Lower values of $\mathrm{pH}$ in ground water compared to surface water probably indicate: (1) Uptake of carbon dioxide $\left(\mathrm{CO}_{2}\right)$ by photosynthesizing organisms in the river, which would increase surface-water $\mathrm{pH}$ values; and (2) equilibration of ground water with soil-zone $\mathrm{CO}_{2}$ or $\mathrm{CO}_{2}$ produced by microbial processes in the saturated zone. These data indicate that the discharge of ground water from the large-area flow system to the river would lower the $\mathrm{pH}$ of river water under conservative mixing conditions.

Concentrations of DO in water from the monitoring wells ranged from less than 0.1 to $5.2 \mathrm{mg} / \mathrm{L}$, with a median value of $0.9 \mathrm{mg} / \mathrm{L}$ (table 10). Concentrations were variable between wells at each site, but at a given well, were relatively constant (fig. 8). An exception to the variability was at McKay Road where there was litthe variability in the DO concentrations from well to well. Concentrations of DO in wells at McKay Road were less than $1 \mathrm{mg} / \mathrm{L}$ during each sampling period, except during November 1992 when concentrations were between 1.4 and $1.8 \mathrm{mg} / \mathrm{L}$ at three of the four sites. The consistently low DO concentrations in water from the McKay Road wells may indicate that there was more organic carbon available to react with DO in aquifer sediments at that site than in aquifer sediment from the other sites. The median percentage of organic-matter content in aquifer sediment collected from well 2B at McKay Road was about four times higher than the median organic-matter content in aquifer sediment collected from well sites at Henderson or Road 8 (table 5). It is not known whether the low concentrations of DO in ground water at McKay Road was characteristic of all ground water underlying the more urbanized parts of the study area, or whether it was a local condition. 

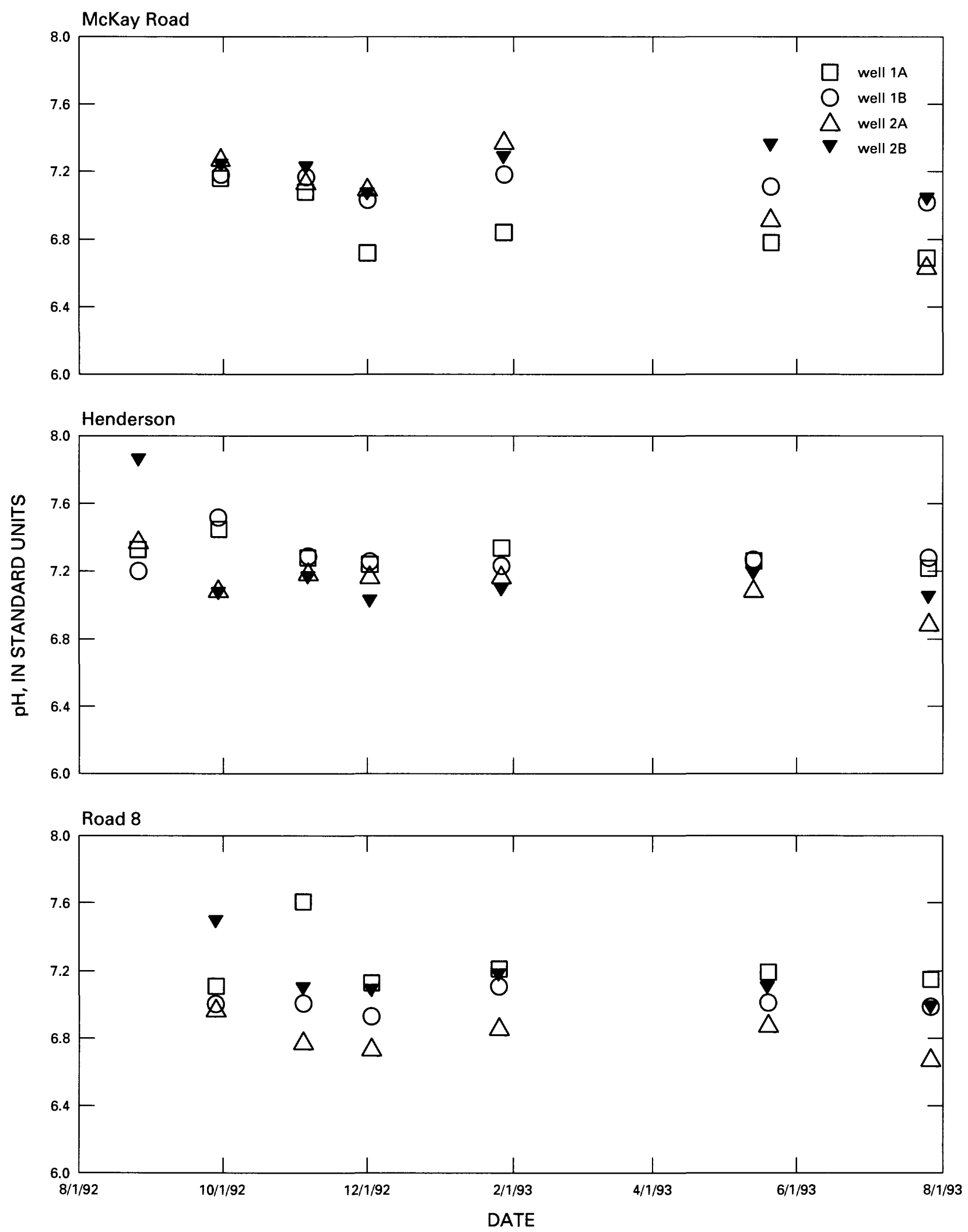

Figure 6. Values of pH in water from wells at McKay Road, Henderson, and Road 8. 


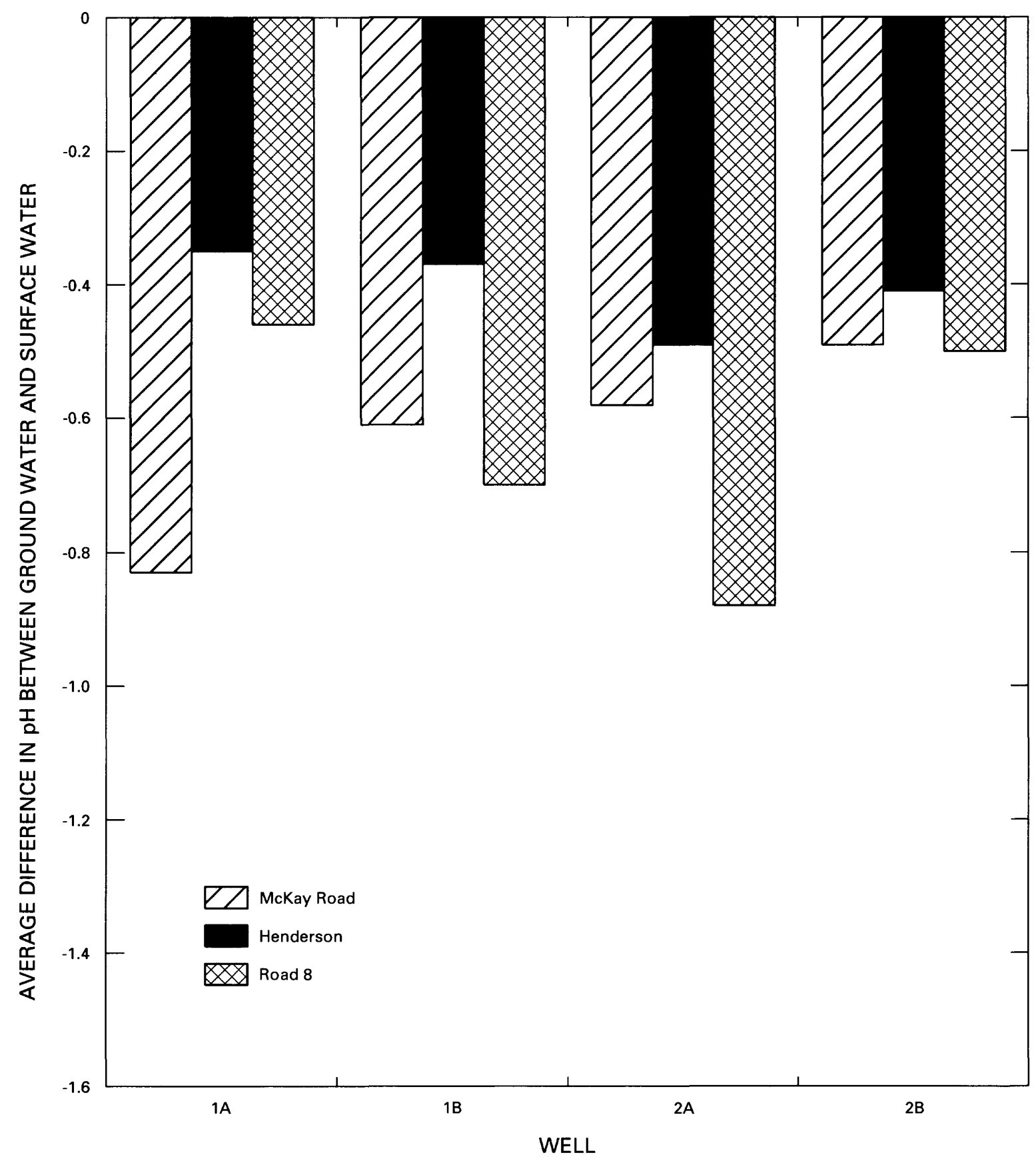

Figure 7. Average difference in pH between ground water and surface water, by well, at McKay Road, Henderson, and Road 8. Negative values indicate the $\mathrm{pH}$ of surface water was greater than the $\mathrm{pH}$ of ground water. 


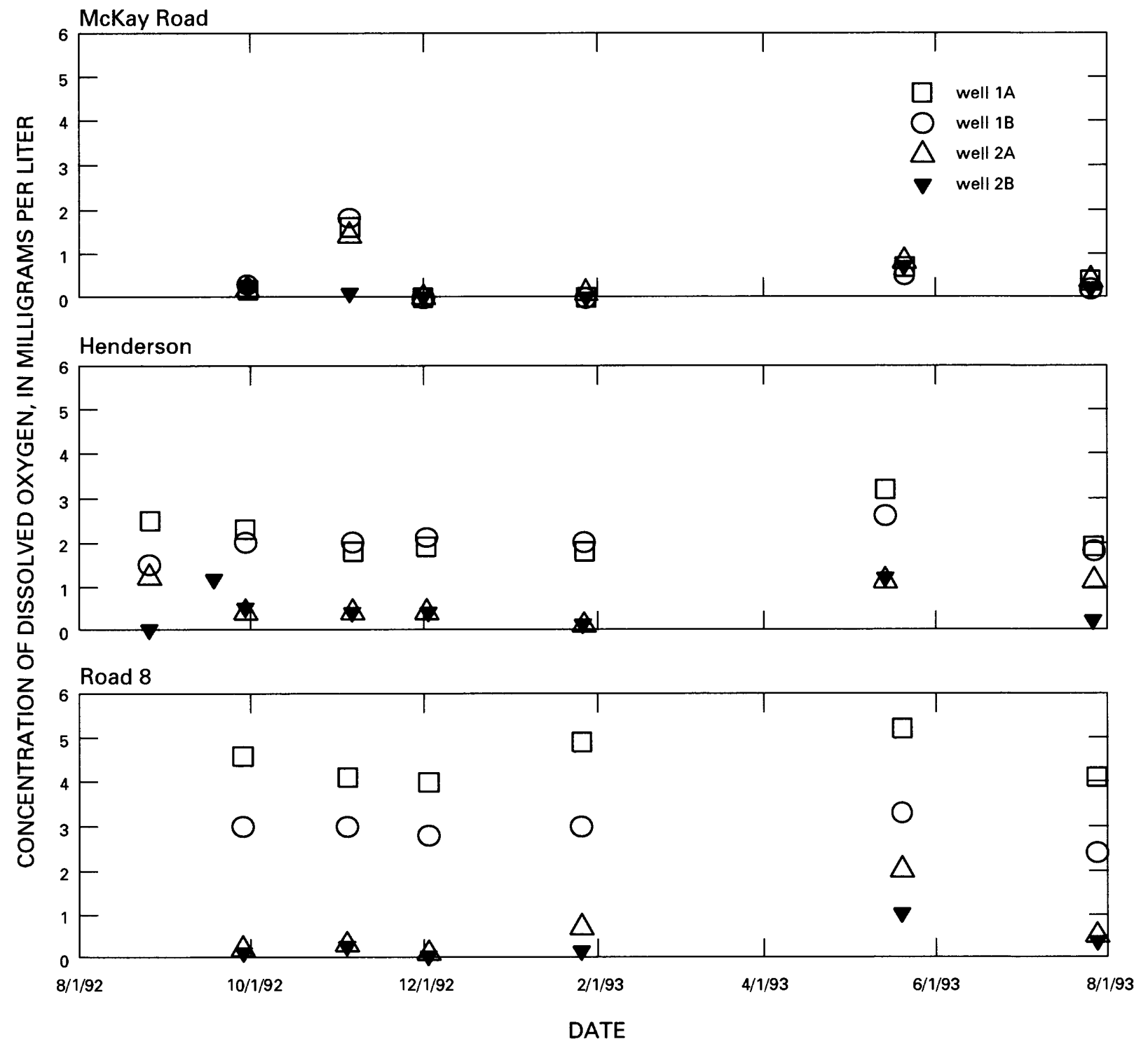

Figure 8. Concentrations of dissolved oxygen in water from wells at McKay Road, Henderson, and Road 8. 
Table 5. Percent of grain sizes less than 0.079 inch and percent organic matter in 0.079 -inch size fraction for riverbed and aquifer sediments at McKay Road, Henderson, and Road 8

[ft, feet; in., inch; REW, right edge of water in river channel; CEN, center of river channel; LEW, left edge of water in river channel]

\begin{tabular}{|c|c|c|c|c|}
\hline $\begin{array}{c}\text { Sample } \\
\text { name }\end{array}$ & $\begin{array}{c}\text { Sample } \\
\text { location } \\
\text { (pl. 1) }\end{array}$ & $\begin{array}{l}\text { Sample depth } \\
\text { (ft below } \\
\text { land surface, } \\
\text { or ft below } \\
\text { sediment/water } \\
\text { interface) }\end{array}$ & $\begin{array}{l}\text { Percent } \\
\text { of sediment, } \\
\text { by welght, } \\
\text { less than } \\
0.079 \text { in. in size }\end{array}$ & $\begin{array}{c}\text { Percent } \\
\text { organlc matter, } \\
\text { by welght, } \\
\text { In less than } \\
0.079 \text {-in size fraction }\end{array}$ \\
\hline McKay Road-REWla & South Platte River at McKay Road. & 0 & 43.9 & 1.3 \\
\hline McKay Road-REWlb & South Platte River at McKay Road. & 0 & 11.6 & .6 \\
\hline McKay Road-REW2 & South Platte River at McKay Road. & 1.0 & 29.4 & 1.9 \\
\hline McKay Road-CENla & South Platte River at McKay Road. & 0 & 33.0 & 3.6 \\
\hline McKay Road-CENlb & South Platte River at McKay Road. & 0 & 27.1 & 5.0 \\
\hline McKay Road-CEN2 & South Platte River at McKay Road. & 1.0 & 20.3 & 4.9 \\
\hline McKay Road 2B & McKay Road-well 2B. & .5 & 64.7 & 1.6 \\
\hline McKay Road 2B & McKay Road-well 2B. & 5.5 & 10.2 & 5.6 \\
\hline McKay Road 2B & McKay Road-well 2B. & 10.5 & 12.4 & 3.5 \\
\hline McKay Road 2B & McKay Road-well 2B. & 15.5 & 18.0 & 1.4 \\
\hline McKay Road 2B & McKay Road-well 2B. & 21.5 & 33.2 & .8 \\
\hline McKay Road 2B & McKay Road-well 2B. & 25.5 & 26.3 & .8 \\
\hline Henderson-REW1 & South Platte River at Henderson. & 0 & 27.4 & .8 \\
\hline Henderson-REW2 & South Platte River at Henderson. & 1.0 & 32.4 & .4 \\
\hline Henderson-CENl & South Platte River at Henderson. & 0 & 32.3 & .5 \\
\hline Henderson-CEN2 & South Platte River at Henderson. & 1.0 & 35.9 & .4 \\
\hline Henderson-LEW1 & South Platte River at Henderson. & .0 & 36.4 & 1.1 \\
\hline Henderson-LEW2 & South Platte River at Henderson. & 1.0 & 41.2 & .4 \\
\hline Henderson 2B & Henderson-well 2B. & .5 & 11.6 & 4.5 \\
\hline Henderson $2 \mathrm{~B}$ & Henderson-well 2B. & 4.5 & 52.2 & .4 \\
\hline Henderson 2B & Henderson-well 2B. & 12.0 & 40.3 & .4 \\
\hline Henderson 2B & Henderson-well 2B. & 17.5 & 35.7 & .3 \\
\hline Henderson 2B & Henderson-well 2B. & 22.0 & 32.5 & .3 \\
\hline Henderson 2B & Henderson-well 2B. & 27.0 & 32.8 & .4 \\
\hline Road 8-REW1 & South Platte River at Road 8. & 0 & 38.3 & 4.7 \\
\hline Road 8-REW2 & South Platte River at Road 8. & 1.0 & 33.1 & .4 \\
\hline Road 8-REW3 & South Platte River at Road 8. & 2.0 & 36.3 & 1.5 \\
\hline Road 8-CEN1 & South Platte River at Road 8. & 0 & 33.4 & .4 \\
\hline Road 8-CEN2 & South Platte River at Road 8. & 1.0 & 32.0 & .5 \\
\hline Road 8-CEN3 & South Platte River at Road 8. & 2.0 & 39.4 & .4 \\
\hline Road 8-LEW 1 & South Platte River at Road 8. & 0 & 41.4 & .4 \\
\hline Road 8-LEW2 & South Platte River at Road 8. & 1.0 & 30.6 & .3 \\
\hline Road 8-LEW3 & South Platte River at Road 8. & 2.0 & 34.6 & .3 \\
\hline Road 8 1B & Road 8-well 1B. & .5 & 66.5 & .9 \\
\hline Road 8 1B & Road 8-well 1B. & 5.0 & 42.6 & .4 \\
\hline Road 8 1B & Road 8-well 1B. & 10.0 & 47.7 & .5 \\
\hline Road 8 1B & Road 8-well 1B. & 15.5 & 38.2 & .4 \\
\hline Road 8 1B & Road 8-well 1B. & 20.5 & 40.9 & .3 \\
\hline Road 8 IB & Road 8-well IB. & 25.5 & 48.7 & .4 \\
\hline
\end{tabular}


Concentrations of $\mathrm{DO}$ were higher in water from wells $1 \mathrm{~A}$ and $1 \mathrm{~B}$ than in water from wells $2 \mathrm{~A}$ and $2 \mathrm{~B}$ at Henderson and Road 8 (fig. 8). The median concentration of DO in water from wells $2 \mathrm{~A}$ and $2 \mathrm{~B}$ at those sites was $0.4 \mathrm{mg} / \mathrm{L}$, whereas the median DO concentration in water from wells $1 \mathrm{~A}$ and $1 \mathrm{~B}$ was $2.7 \mathrm{mg} / \mathrm{L}$. The highest DO concentrations, greater than $4 \mathrm{mg} / \mathrm{L}$, were measured in water from well $1 \mathrm{~A}$ at Road 8 . Based on ongoing regional studies of ground water in parts of the alluvial aquifer overlain by agricultural land-use settings (U.S. Geological Survey, unpublished data, 1993), the relatively high DO concentrations in water from the $1 \mathrm{~A}$ and $1 \mathrm{~B}$ wells at Henderson and Road 8 are more characteristic of DO concentrations in the largearea flow system than the low concentrations of DO in the $2 \mathrm{~A}$ and $2 \mathrm{~B}$ wells. The differences in DO concentrations between the $1 \mathrm{~A} / 1 \mathrm{~B}$ and $2 \mathrm{~A} / 2 \mathrm{~B}$ well pairs at the Henderson and Road 8 sites could indicate differences in the degree of mixing between the large-area and small-area flow systems. As will be discussed in the "Small-Area Flow System" section, water in the smallarea flow system was more depleted in DO than water in the large-area flow system.

The median instantaneous daytime concentration of DO in the South Platte River, based on measurements at the McKay Road, Henderson, and Road 8 sites, was $8.4 \mathrm{mg} / \mathrm{L}$, which means that even though ground water in the large-area flow system was oxygenated, discharge of this water to the river would have lowered surface-water DO concentrations under conservative mixing conditions. For example, in reach 2 of the South Platte River extending from 104th Avenue to just upstream from the Brighton Ditch headgate (pl. 1), if the concentration of DO in surface water entering the reach is assumed to be $8.5 \mathrm{mg} / \mathrm{L}$, if the concentration of DO in ground-water discharge from the large-area flow system is assumed to be $2.5 \mathrm{mg} / \mathrm{L}$, and if 17 percent of streamflow in the reach comes from ground-water discharge ( 17 percent is the median value for reach 2 from table 4 ), the concentration of DO in the river at the downstream end of the reach would be about $7.5 \mathrm{mg} / \mathrm{L}$. If $7.5 \mathrm{mg} / \mathrm{L}$ represented the concentration of DO in surface water entering reach 3 of the South Platte River extending from 160th Avenue to Highway 52, mass-balance calculations indicate that the concentration of DO in the river at the downstream end of the reach would be about $7.0 \mathrm{mg} / \mathrm{L}$, assuming that 11 percent of the river flow is from ground-water discharge ( 11 percent is the median value for reach 3 from table 4).

Concentrations of dissolved nitrite plus nitrate in ground water from the monitoring wells ranged from less than 0.01 to $37.93 \mathrm{mg} / \mathrm{L}$ as nitrogen, and concentrations of dissolved ammonium ranged from less than 0.1 to $9.2 \mathrm{mg} / \mathrm{L}$ as nitrogen (table 10 ). Based on sepa- rate nitrite analyses, essentially all of the dissolved nitrite plus nitrate was as nitrate. Concentrations of nitrite plus nitrate and ammonium varied greatly between sites, between wells at a given site, and with depth (table 10 and figs. 9 and 10). Concentrations of dissolved nitrite plus nitrate generally increased going from ground water at McKay Road to ground water at Road 8, whereas dissolved-ammonium concentrations decreased. Water from well $1 \mathrm{~A}$ at Road 8 had the highest measured concentration of nitrite plus nitrate, and water from well 1A at McKay Road had the highest measured ammonium concentration (table 10).

The large variability in concentrations of nitrite plus nitrate and ammonium between wells at a given site and between sites indicates that ground-water discharge as a source of dissolved-nitrogen species to the river also was spatially variable. For example, median concentrations of nitrite plus nitrate in the $1 \mathrm{~A} / 1 \mathrm{~B}$ and $2 \mathrm{~A} / 2 \mathrm{~B}$ wells at McKay Road were less than $0.01 \mathrm{mg} / \mathrm{L}$ as nitrogen, whereas the median concentration in the river was $4.40 \mathrm{mg} / \mathrm{L}$ as nitrogen. This indicates that ground-water discharge from the large-area flow system was not a substantial source of nitrite plus nitrate to the river at McKay Road. In contrast, the median concentrations of nitrite plus nitrate in the $1 \mathrm{~A} / 1 \mathrm{~B}$ wells and surface water at Road 8 were 24.50 and $5.23 \mathrm{mg} / \mathrm{L}$ as nitrogen, indicating that ground-water discharge from the large-area flow system on the east side of the river at Road 8 was probably a substantial source of nitrite plus nitrate to surface water. However, the low median concentration of nitrite plus nitrate in the $2 \mathrm{~A} / 2 \mathrm{~B}$ wells at Road $8(0.29 \mathrm{mg} / \mathrm{L}$ as nitrogen $)$ indicates that the flow system on the west side of the river was not a substantial source of nitrite plus nitrate to the river. Median concentrations of ammonium in the monitoring wells at McKay Road were about the same as the median concentration of ammonium in the river $(5.3 \mathrm{mg} / \mathrm{L}$ at the $1 \mathrm{~A} / 1 \mathrm{~B}$ wells, $5.4 \mathrm{mg} / \mathrm{L}$ at the $2 \mathrm{~A} / 2 \mathrm{~B}$ wells, $5.1 \mathrm{mg} / \mathrm{L}$ in the river, all as nitrogen).

Concentrations of dissolved phosphorus in water from the monitoring wells ranged from less than 0.01 to $7.24 \mathrm{mg} / \mathrm{L}$ as phosphorus (fig. 11). The highest concentrations were measured in water from wells at McKay Road, and the lowest concentrations were in water from wells at Road 8. McKay Road was the only site at which water from the monitoring wells had dissolved-phosphorus concentrations higher than dissolved-phosphorus concentrations measured in surface water at the same site (table 10), indicating that the site at McKay Road was the only one of the three sites having monitoring wells where the large-area flow system could be an important source of dissolved phosphorus to the river. 


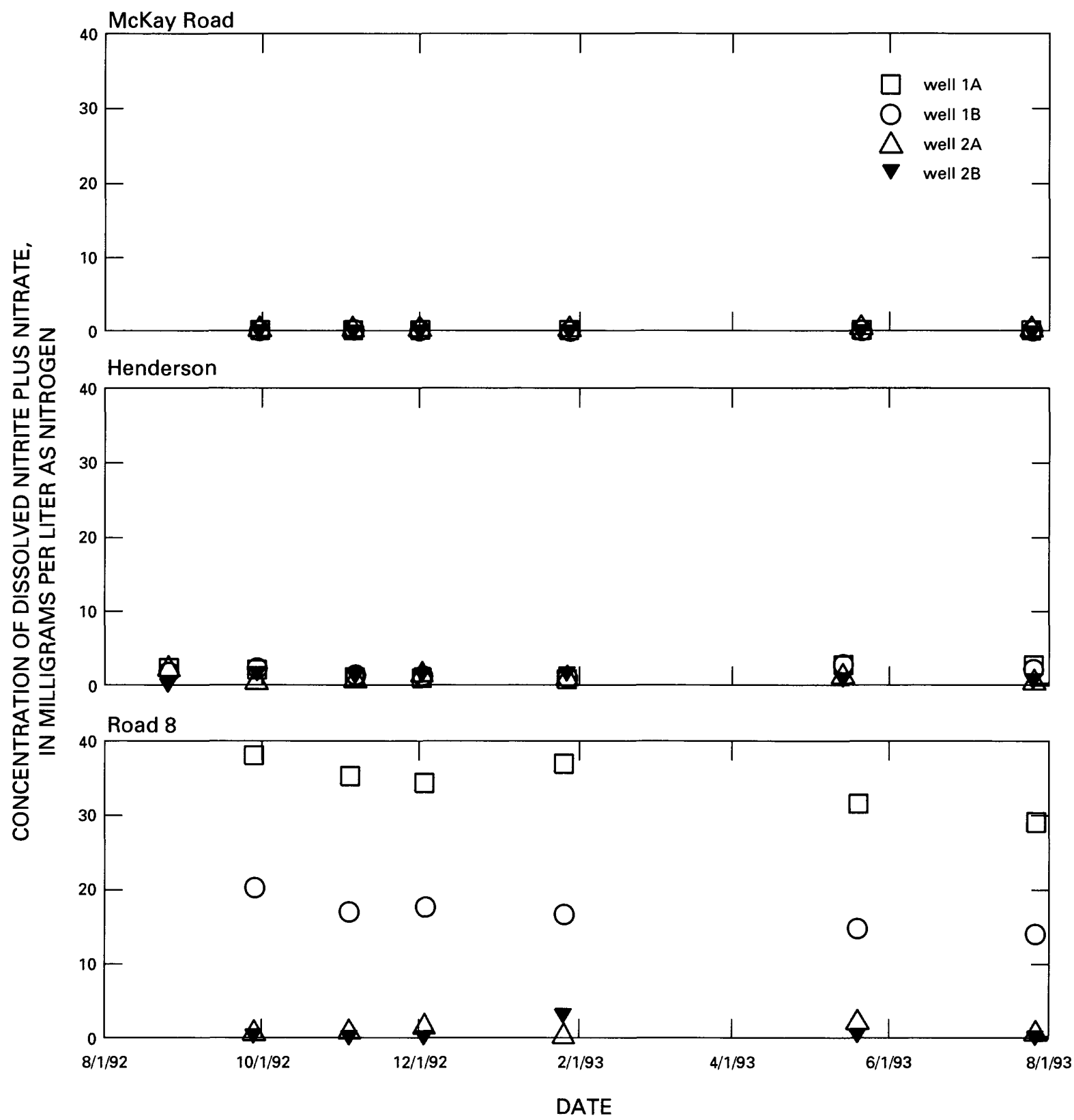

Figure 9. Concentrations of dissolved nitrite plus nitrate in water from wells at McKay Road, Henderson, and Road 8.

\section{Small-Area Flow System}

Values of $\mathrm{pH}$ in water from the piezometers screened $1 \mathrm{ft}$ below the sediment/water interface ranged from 6.71 to 8.64 , with a median value of 7.33 (fig. 12 and table 9). As with values of $\mathrm{pH}$ in ground water from the monitoring wells, values of $\mathrm{pH}$ in ground water from the small-area flow system generally were lower than values in the river (fig. 12). Measurements of $\mathrm{pH}$ indicate that values of $\mathrm{pH}$ at depths of less than 84 in. below the sediment/water interface were less than values in the surface water (table 10 and fig. 13). These data indicate that water discharging from the small-area flow system had the potential to lower $\mathrm{pH}$ values in the river.
Concentrations of DO in water from the piezometers ranged from less than 0.1 to $1.7 \mathrm{mg} / \mathrm{L}$, with a median value of $0.2 \mathrm{mg} / \mathrm{L}$ (fig. 14 and table 9). The median concentration of DO in ground water from below the sediment/water interface varied in different reaches of the river from between 0.2 and $0.3 \mathrm{mg} / \mathrm{L}$; however, the median concentration in each reach was substantially lower than the median DO concentration $(2.5 \mathrm{mg} / \mathrm{L})$ in ground water from the $1 \mathrm{~A} / 1 \mathrm{~B}$ wells at Henderson and Road 8. DO concentrations in ground water from the $1 \mathrm{~A} / 1 \mathrm{~B}$ wells at Henderson and Road 8 are considered to be representative of the DO concentrations in the large-area flow system in the agricultural area. Concentrations of DO in ground water from the small-area flow system were substantially lower than 


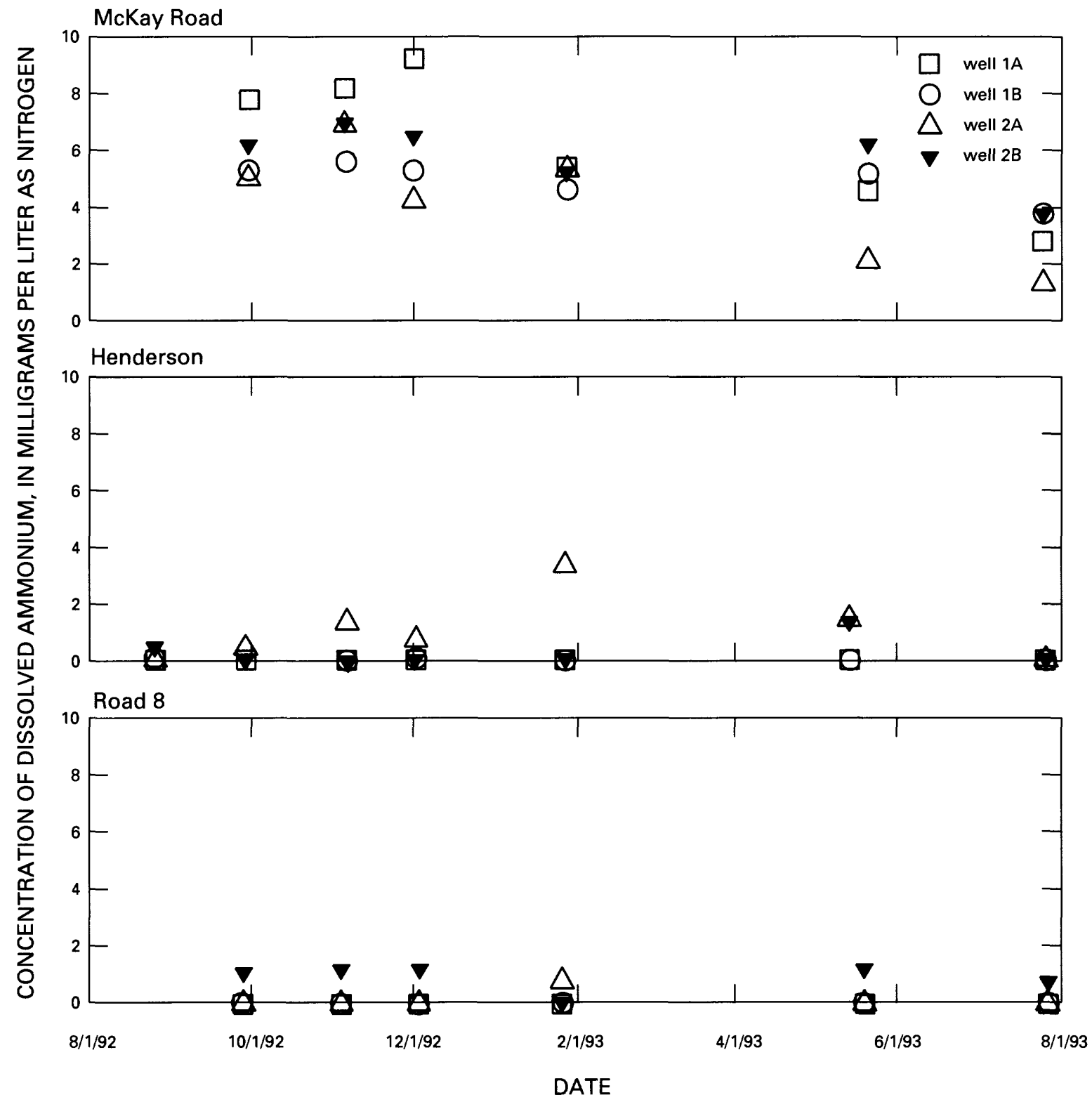

Figure 10. Concentrations of dissolved ammonium in water from wells at McKay Road, Henderson, and Road 8.

concentrations in the river and in ground water from the 1A/1B wells at Henderson and Road 8, regardless of the difference in hydraulic head between ground water and surface water (fig. 15). These data indicate that sediments in the small-area flow system were a sink for DO in water discharging to the river from the large-area flow system and for surface water infiltrating into the bed sediments.

The fact that sediments in the small-area flow system were a sink for DO indicates that a source of organic carbon was available to micro-organisms in the small-area flow system that was not available to microorganisms in the large-area flow system. Comparison of the organic-matter content in sediments from the monitoring-well sites at Henderson and Road 8 with the organic-matter content in bed sediments at those sites indicates that there was not a substantial difference in the amount of solid organic matter between the sediments (table 5). An exception to this was the generally higher organic-matter content of bed sediments at the sediment/water interface compared to sediments below the interface or compared to aquifer sediment below the water table adjacent to the river. These data indicate that solid organic matter may not be the main source of organic carbon used by micro-organisms below the sediment/water interface to reduce DO in the small-area flow system. A more likely source of the organic carbon was dissolved or suspended organic carbon introduced into the small-area flow system from the river. Concentrations of total organic carbon in surface water were greater than concentrations in ground water below the sediment/water interface (fig. 16), 


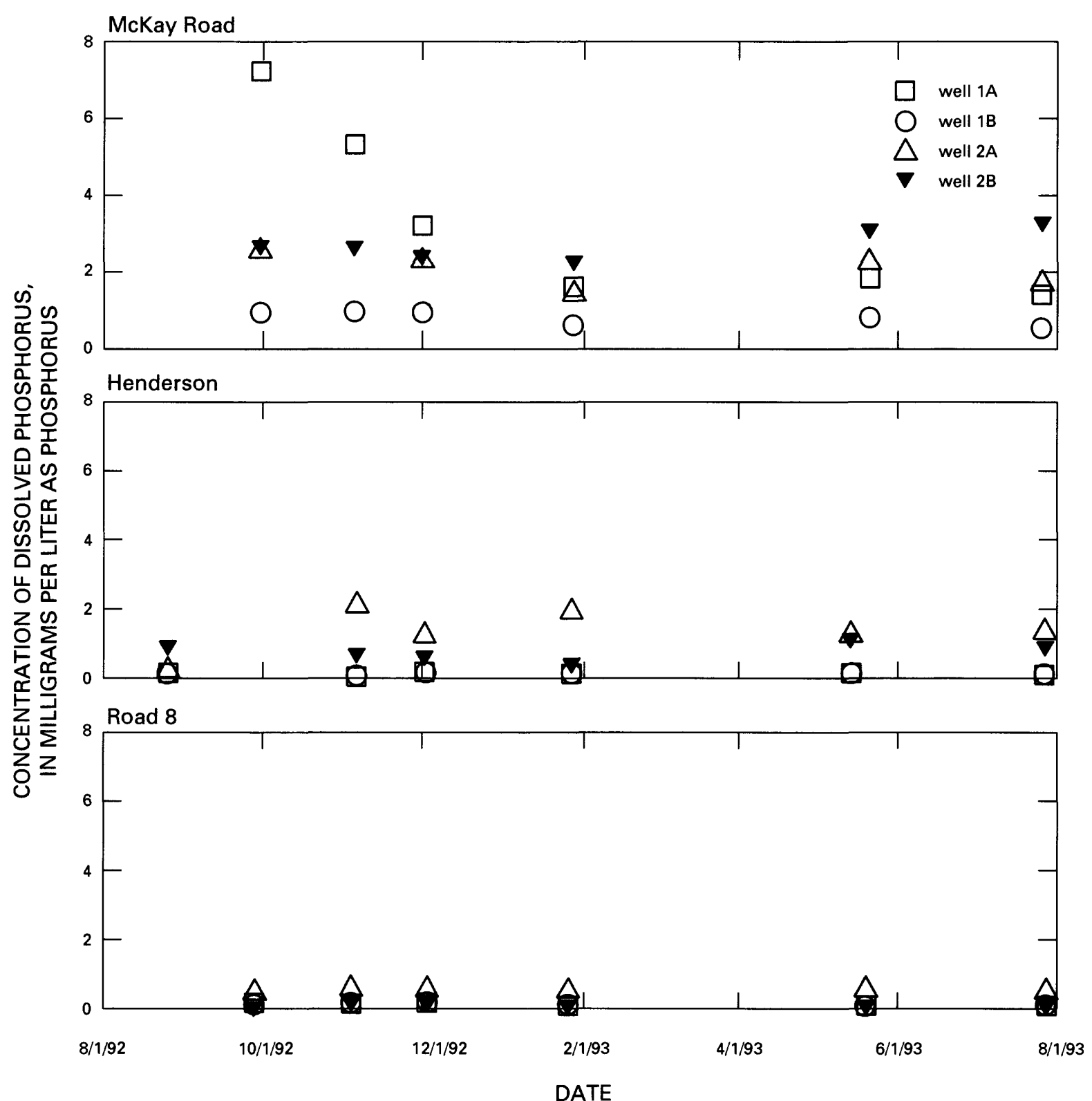

Figure 11. Concentrations of dissolved phosphorus in water from wells at McKay Road, Henderson, and Road 8.

indicating that advective movement of surface water into underlying sediments would increase organic carbon concentrations in ground water in the sediments. Changes in flow directions in the small-area flow system may have allowed river water to infiltrate the bed sediments. Concentrations of total organic carbon decrease with depth below the sediment/water interface, indicating that the river could have acted as a source of organic carbon when it infiltrated the sediments. The presence of relatively high concentrations of organic carbon in water and sediments in all of the McKay Road samples probably explains why there was little DO in any water samples from that site.
The process of DO removal in the small-area flow system affected DO concentrations in the river in at least two ways. The mass-balance example given in the "Large-Area Flow System" section indicated that ground-water discharge to the river would lower DO concentrations in the river between 104th Avenue and Highway 52 from 8.5 to $7.0 \mathrm{mg} / \mathrm{L}$. However, in that mass-balance example, the concentration of DO chosen for ground-water discharge was $2.5 \mathrm{mg} / \mathrm{L}$, which was the median concentration of DO in water from the $1 \mathrm{~A} / 1 \mathrm{~B}$ wells at Henderson and Road 8 . If the median DO concentration $(0.2 \mathrm{mg} / \mathrm{L})$ measured in water from the small-area flow system is used as the DO concentration for ground-water discharge from the 

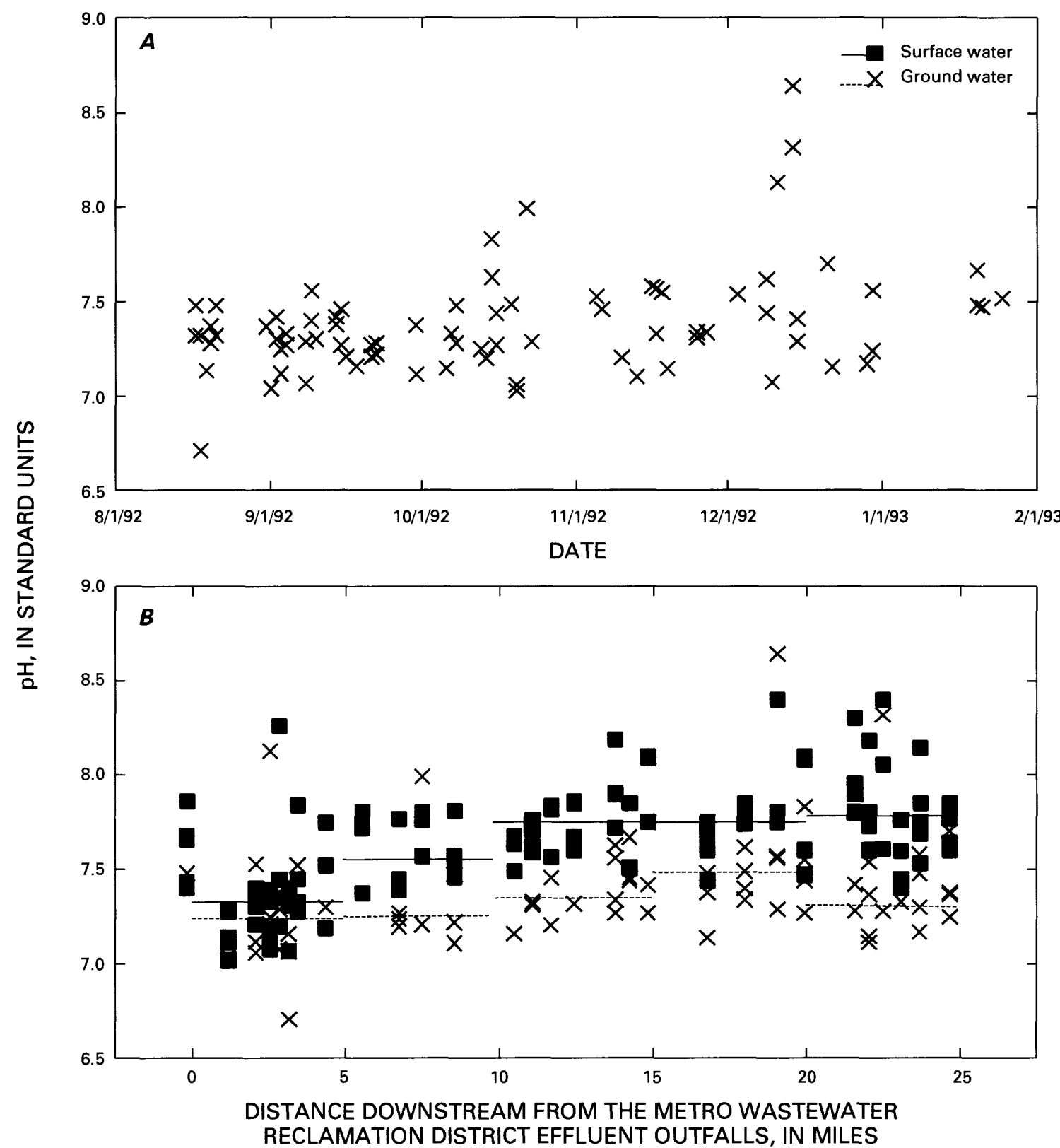

Figure 12. Values of $\mathrm{pH}$ in (A) ground water 1 foot below the sediment/water interface with time, and (B) surface water and ground water 1 foot below the sediment/water interface with distance downstream from the Metro Wastewater Reclamation District effluent outfalls. Solid and dashed lines in (B) show median values of pH for samples 0 to 5,5 to 10,10 to 15,15 to 20 , and greater than 20 miles downstream from the effluent outfalls.

large-area flow system, then DO concentrations in the river would be lowered from 8.5 to $6.3 \mathrm{mg} / \mathrm{L}$ under conservative mixing conditions.

Concentrations of DO in the river could have been lowered further due to the daily movement of surface water in and out of the bed sediments. Data indicate that DO was removed from surface water when it entered the small-area flow system in the bed sediments (fig. 15); therefore, if that water later discharged back into the river, it would lower DO concentrations in the river even though there was no net addition of water to the river. Based on the hourly measurements of incremental ground-water discharge at Road 8 (fig. 5), the net amount of surface water that moved into the bed sediments and then came back out was about $0.26\left(\mathrm{Mft}^{3} / \mathrm{d}\right) / \mathrm{mi}$ over 24 hours. This amount was about 54 percent of the net amount $\left[0.48\left(\mathrm{Mft}^{3} / \mathrm{d}\right) / \mathrm{mi}\right]$ of ground water that discharged from the large-area flow system to that reach of river on November 30, 1992 (table 4). 


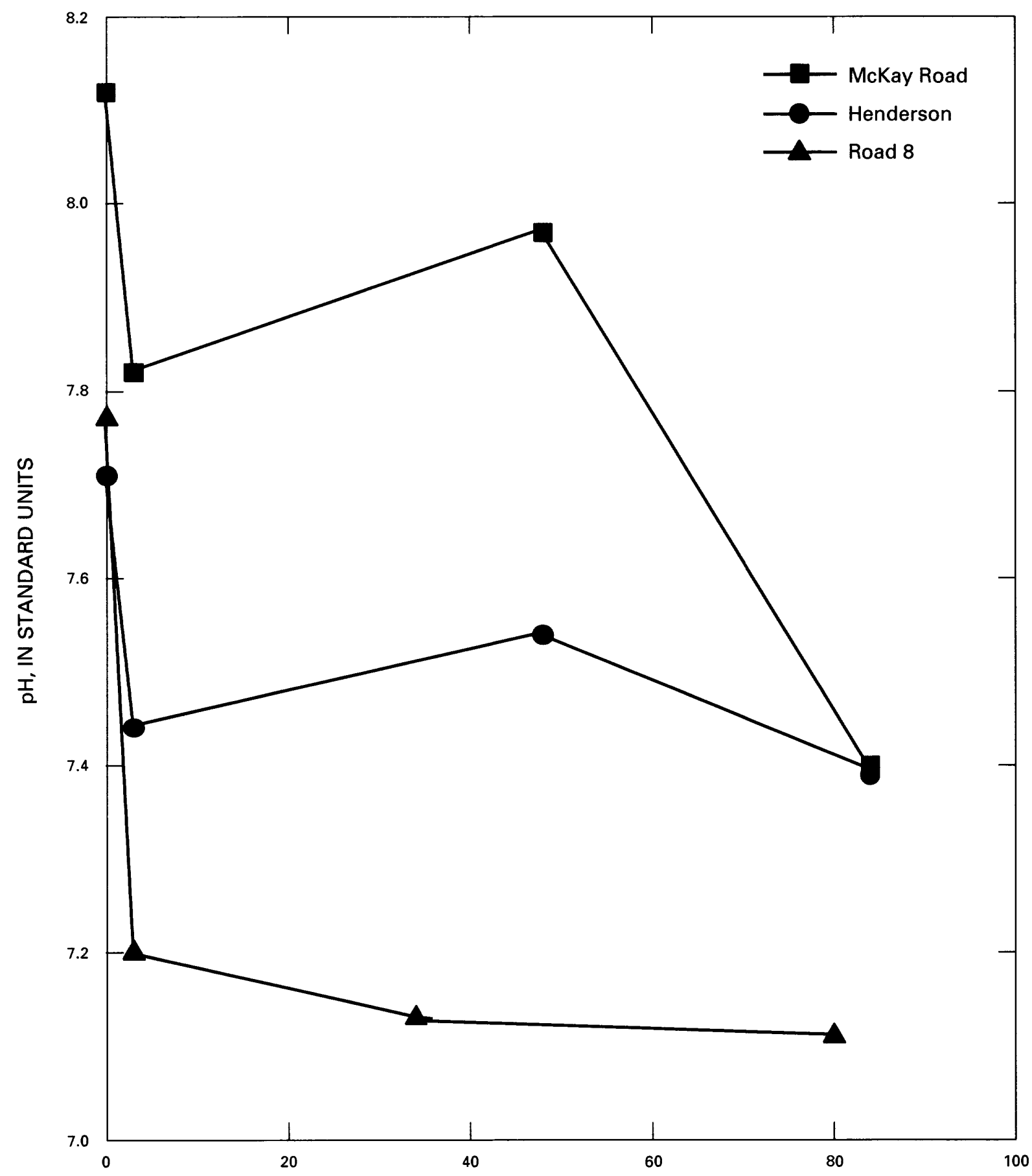

DEPTH BELOW SEDIMENT/WATER INTERFACE, IN INCHES

Figure 13. Values of $\mathrm{pH}$ in ground water with depth below the sediment/water interface at McKay Road, Henderson, and Road 8. Measurements at McKay Road, Henderson, and Road 8 were made on October 1, 1992; August 27, 1992; and August 25, 1992, respectively. Values for surface water are indicated at a depth of 0 inches below the sediment/water interface. 


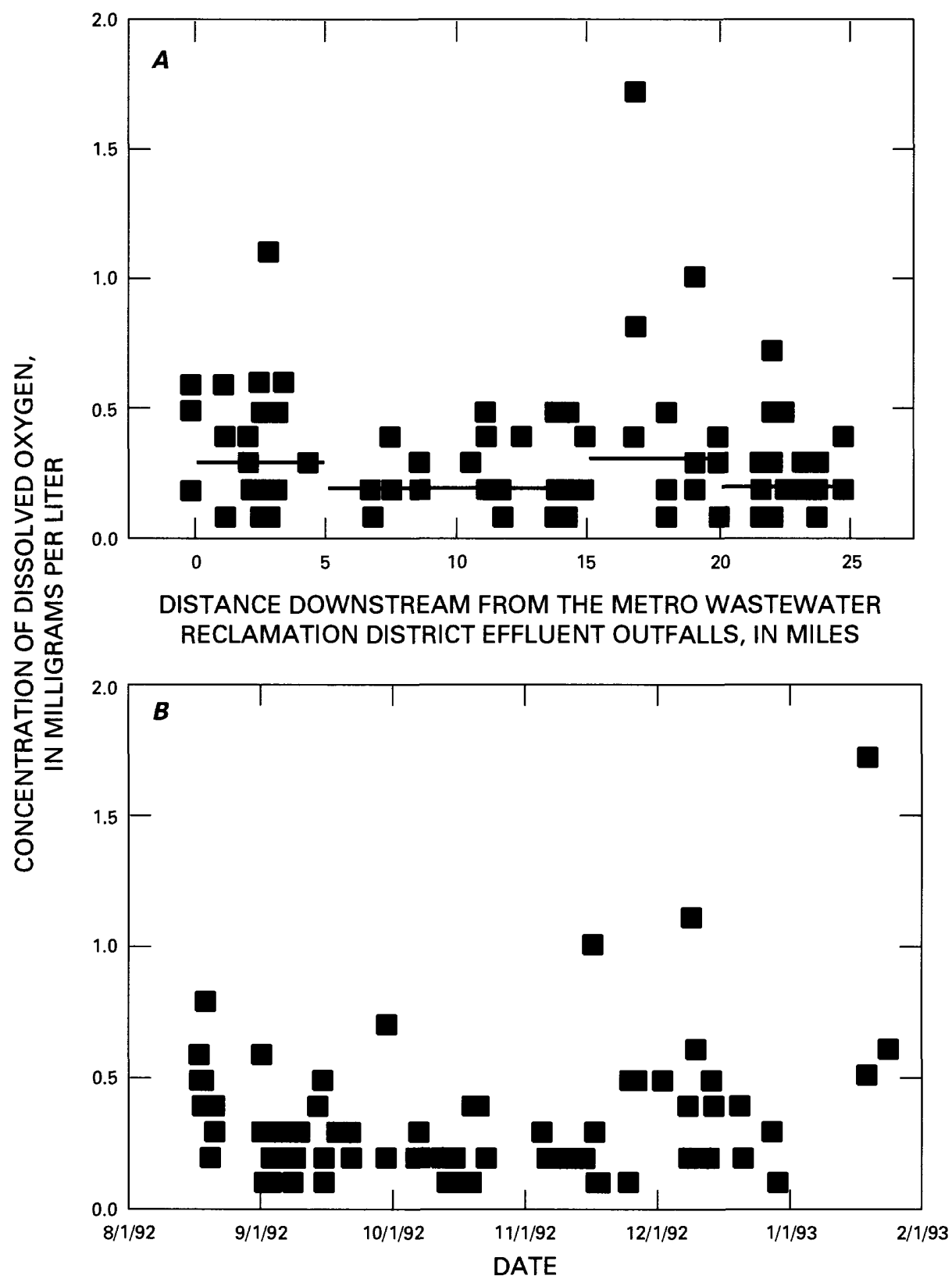

Flgure 14. Concentrations of dissolved oxygen in ground water 1 foot below the sediment/water interface with (A) distance downstream from the Metro Wastewater Reclamation District effluent outfalls, and (B) time. Solid line in (A) shows median concentration of dissolved oxygen for samples 0 to 5,5 to 10,10 to 15,15 to 20, and greater than $\mathbf{2 0}$ miles downstream from the effluent outfalls. 


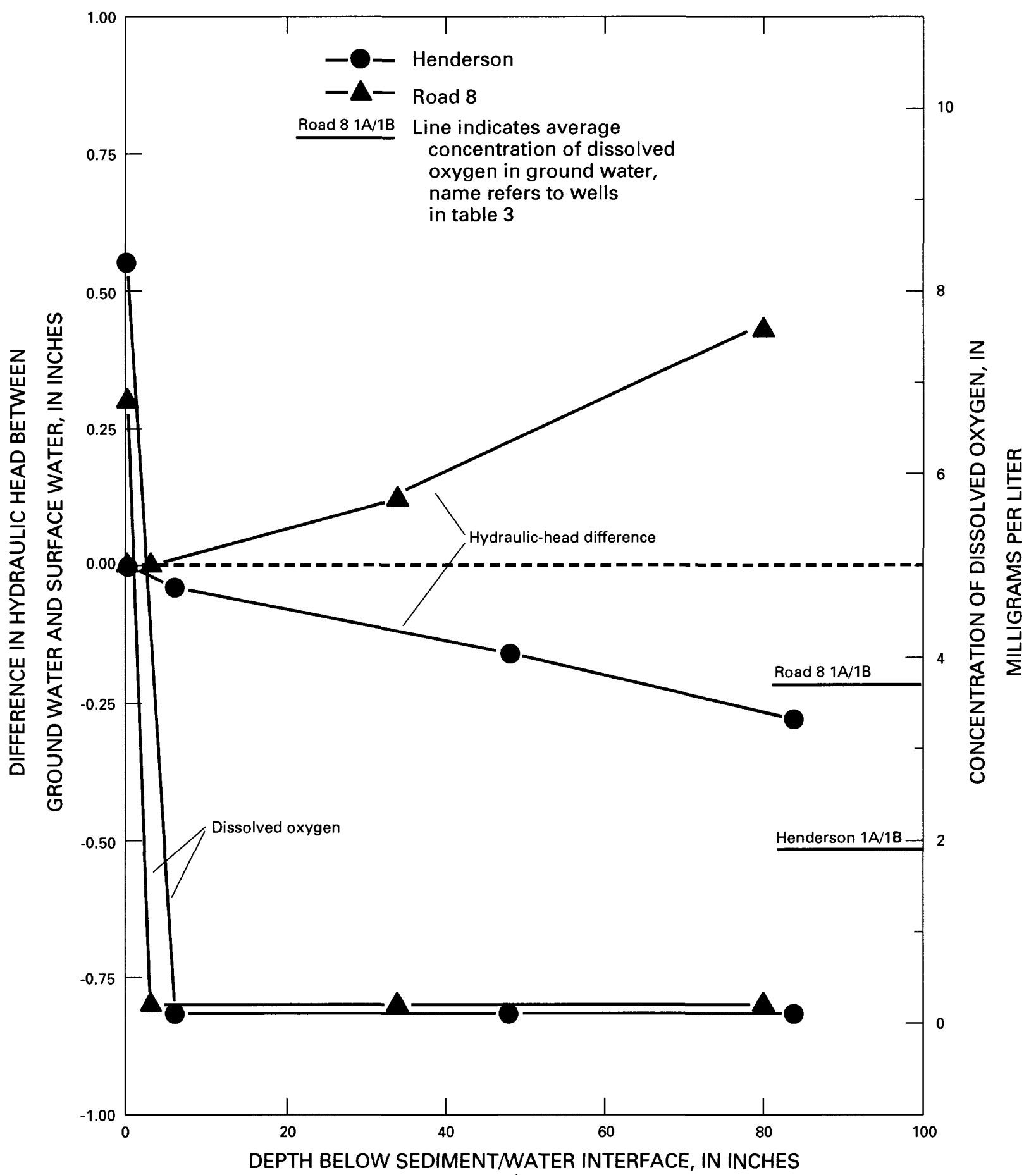

Flgure 15. Concentrations of dissolved oxygen and differences in hydraulic head between ground water and surface water with depth below the sediment/water interface. Measurements at Henderson and Road 8 were made on October 30,1992, and August 25, 1992. Values for surface water indicated at a depth of 0 inches below the sediment/ water interface. 


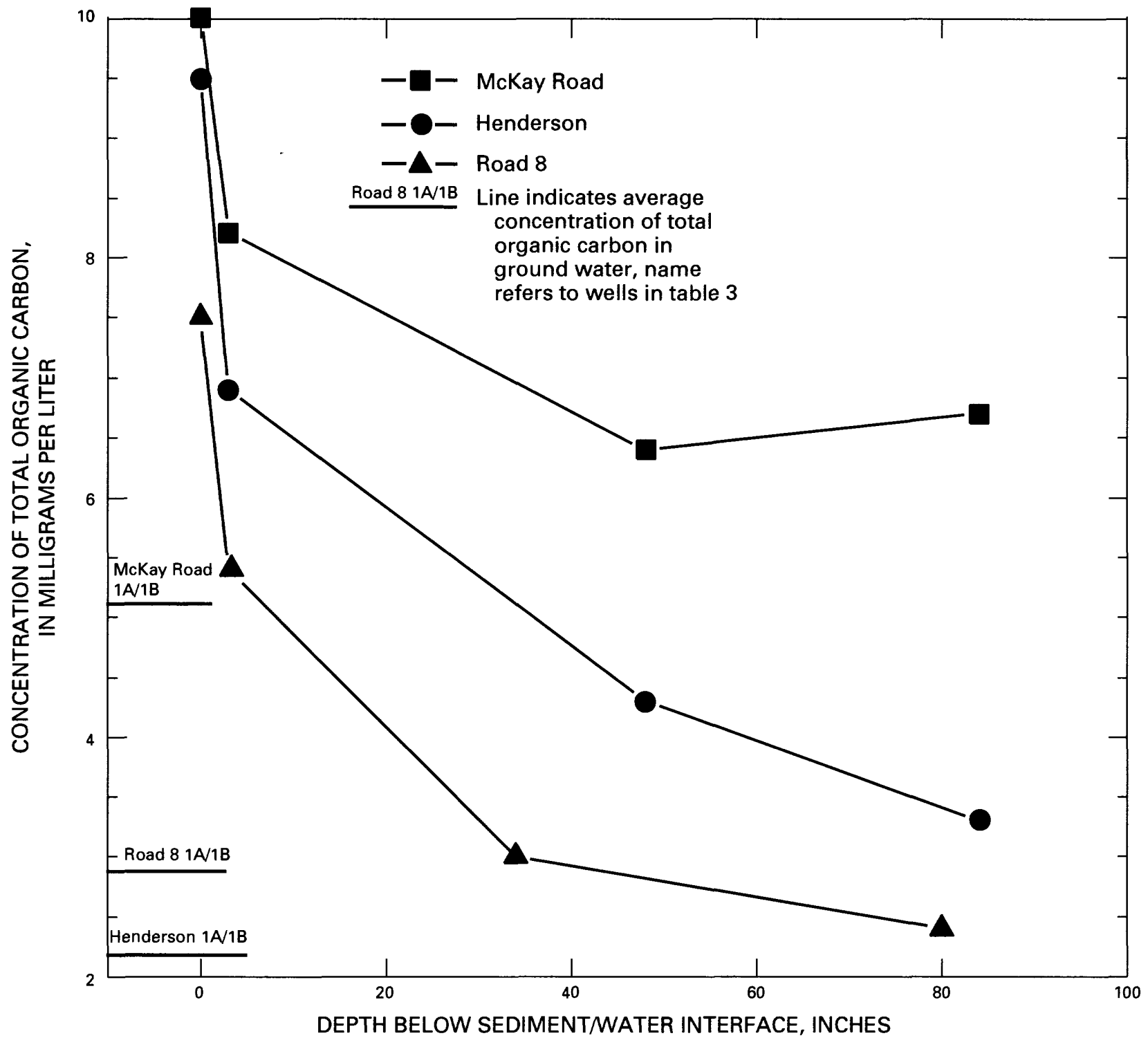

Figure 16. Concentrations of total organic carbon in ground water with depth below the sediment/water interface at McKay Road, Henderson, and Road 8. Samples at McKay Road, Henderson, and Road 8 were collected on October 1, 1992; October 5, 1992; and September 25, 1992, respectively. Values for surface water indicated at a depth of 0 inches below the sediment/water interface.

Concentrations of dissolved nitrite plus nitrate, ammonium, and phosphorus in water samples from the piezometers at the 30 cross-section sites ranged from less than 0.01 to $8.98 \mathrm{mg} / \mathrm{L}$ as nitrogen, less than 0.1 to $15.3 \mathrm{mg} / \mathrm{L}$ as nitrogen, and 0.28 to $7.22 \mathrm{mg} / \mathrm{L}$ as phosphorus (table 9). The median concentrations of dissolved nitrite plus nitrate, ammonium, and phosphorus were $1.22 \mathrm{mg} / \mathrm{L}$ as nitrogen, $1.7 \mathrm{mg} / \mathrm{L}$ as nitrogen, and $1.41 \mathrm{mg} / \mathrm{L}$ as phosphorus. Concentrations of nitrite plus nitrate in ground water below the sediment/water interface increased with distance downstream from the MWRD plant, whereas concentrations of ammonium decreased (fig. 17). Concentrations of phosphorus showed no consistent pattern of change with distance downstream from the MWRD plant. The pattern of concentration changes observed for nitrite plus nitrate and ammonium with distance downstream from the MWRD plant is similar to what has been observed in the river. The pattern of concentration changes in the river is generally attributed to the addition of ammonium to the river from the MWRD plant, followed by the conversion of ammonium to nitrate by nitrifying bacteria as the water flows downstream. Due to the movement of surface water into and out of the bed sediments, it is likely that at least part of the concentration pattern of nitrite plus nitrate and ammonium observed in the small-area flow system (fig. 17) is the result of similar processes. However, other processes also were active in the smallarea flow system. 


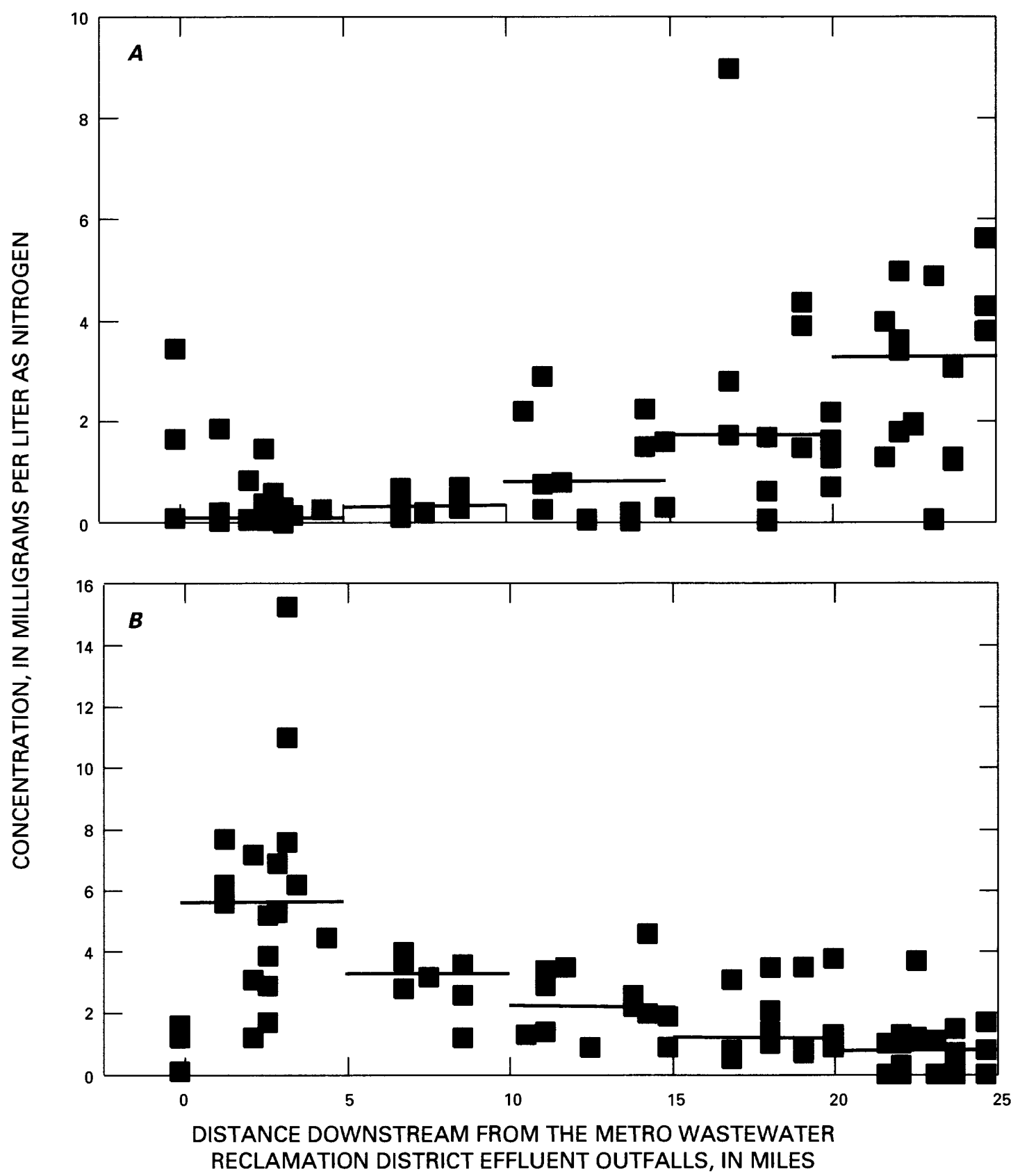

Figure 17. Concentrations of (A) dissolved nitrite plus nitrate, and (B) dissolved ammonium in ground water 1 foot below the sediment/water interface with distance downstream from the Metro Wastewater Reclamation District effluent outfalls. Solid line shows median concentrations for samples 0 to 5,5 to 10 , 10 to 15,15 to 20 , and greater than 20 miles downstream from the effluent outfalls. 
Chemical and isotopic data indicate that bed sediments in the upper reaches of the study area were a source of ammonium to the small-area flow system. For example, chemical and isotopic analyses of dissolved ammonium in ground water below the sediment/water interface at McKay Road on November 2, 1992, represent ammonium production in the sediments under the river at this site (fig. 18). Ammonium concentrations were higher at a depth of 12 in. below the sediment/water interface than at other sampled depths, and the $\delta^{15} \mathrm{~N}$ composition of the ammonium at a depth of 12 in. was about 9 to 12 per mil lighter than the $\delta^{15} \mathrm{~N}$ composition of ammonium at other depths (table 6). Ammonium produced in-situ generally is isotopically lighter than ammonium that has been transported and subjected to reactions like nitrification that cause the residual ammonium to become isotopically enriched. Although the hydraulichead difference at the time of measurement was directed from the river into the sediments, indicating no advective flux to the river of ammonium at the 12-in depth, the 24-hour data indicate that an upward flux of ammonium sometime during the day was likely. The relatively high organic-matter content of bed sediments at McKay Road indicates that the ammonium probably was derived from the mineralization of organic nitrogen in sedimentary organic matter. The concentration of orthophosphate in ground water below the sediment/ water interface also was higher at a depth of 12 in. than at other sampled depths on the same date, indicating that the mineralization of organic matter may have provided dissolved phosphorus to the small-area flow system.

Sedimentary organic matter probably was the source of high concentrations of dissolved ammonium and orthophosphate in ground water beneath the river at cross-section site 6 (table 9). At this site, the sedimentary organic matter may have been excrement from waterfowl (table 6). This reach of the river was densely populated by waterfowl during the fall. The nitrogen-isotope composition of ammonium in ground water at the site on December 22, 1992, was the same as the isotopic composition of fresh waterfowl excrement (table 6). The isotopic composition of ammonium in weathered waterfowl excrement was about 4 per mil heavier than that in the fresh material, indicating that the ammonium in the weathered material had mineralized and lost isotopically light nitrogen. Although there was not a net discharge of ground water to the river at site 6 at the time of sampling on
December 22, 1992 (table 9), hydraulic head at the piezometer from which the isotope sample was collected was higher than the head in the river.

In addition to the bed sediments being sources of dissolved-nitrogen species to ground water in the small-area flow system, they also were sinks for dissolved-nitrogen species. The combination of low DO concentrations in ground water below the sediment/water interface and the presence of nitrate provided suitable conditions for denitrification to occur in the small-area flow system. Laboratory incubations indicated a measurable potential for denitrification in the bed sediments (table 7). Rates of denitrification (as indicated by $\mathrm{N}_{2} \mathrm{O}$ production) in riverbed sediments from 88th Avenue and McKay Road sites increased substantially when nitrate concentrations in pore water in those sediments were increased from low in-situ values, whereas the increase in denitrification rate in sediments from Road 8 site was much smaller when nitrate concentrations were increased from high in-situ values. These results indicate that (1) denitrification rates in bed sediments from 88 th Avenue and McKay Road sites were more limited by the availability of nitrate than denitrification rates in sediments from Road 8 site; and (2) any nitrate entering bed sediments in the vicinity of 88th Avenue or McKay Road sites, 3 to $6 \mathrm{mi}$. downstream from the MWRD, would probably be reduced to $\mathrm{N}_{2}$, which is consistent with the low concentrations of dissolved nitrite plus nitrate in ground water from the small-area flow system at those sites (fig. 17). Rates of denitrification in sediments from the Henderson and Road 8 sites increased proportionally more than denitrification rates in sediments from 88th Avenue and McKay Road sites when glucose was added to the sediments, which indicates that denitrification rates in riverbed sediments from the Henderson and Road 8 sites were more limited by the availability of organic carbon than denitrification rates in sediments from the 88th Avenue and McKay Road sites. This interpretation is consistent with measurements of organic-matter content that indicated a larger percentage of organic matter in riverbed sediments from the McKay Road site than in sediments from the Henderson or Road 8 sites (table 5). In general, the presence of a denitrifying potential in sediments in the small-area flow system indicates that the small-area flow system could be a sink for nitrate in ground water from the large-area flow system and for nitrate in river water. 

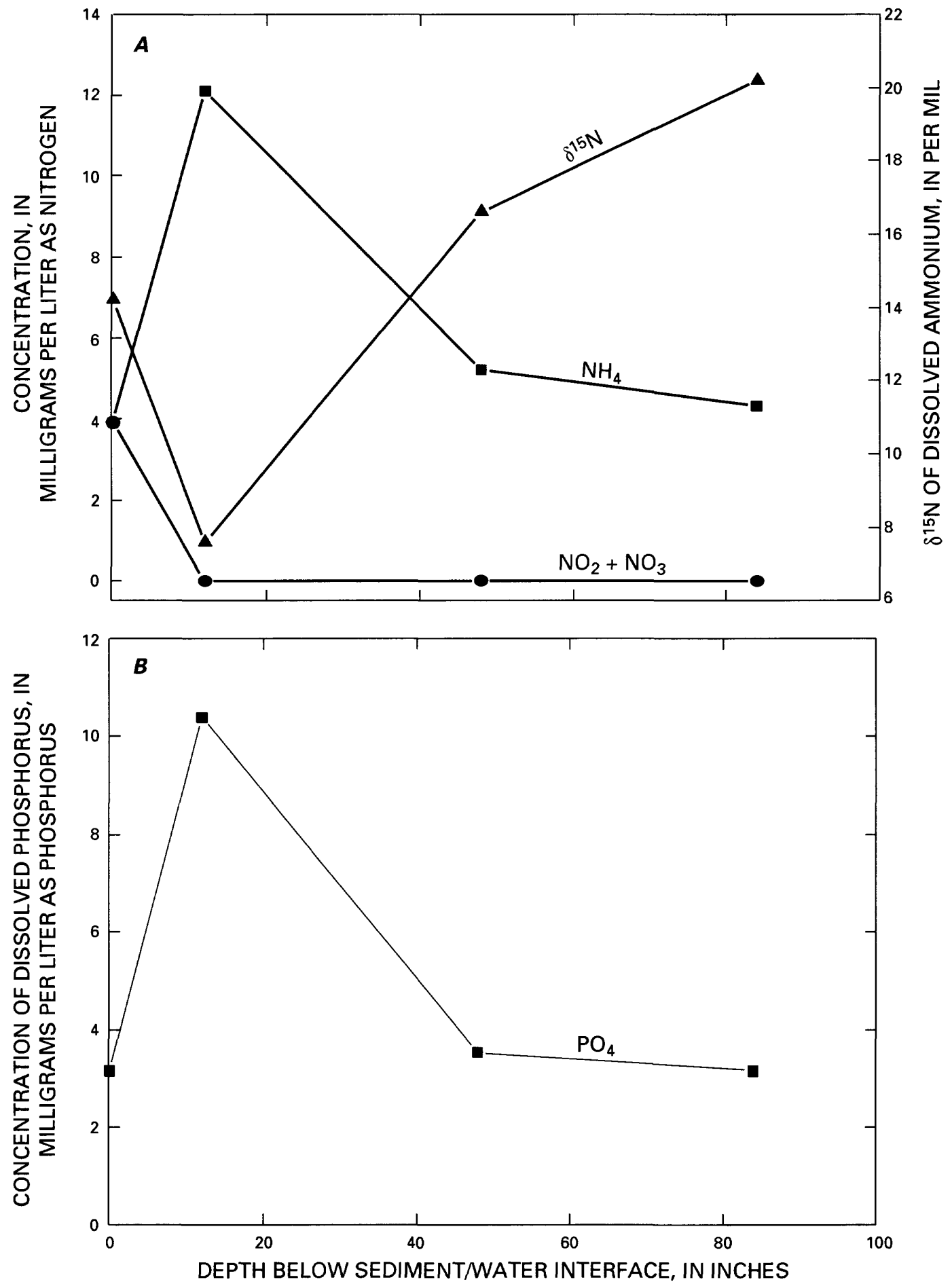

Figure 18. Concentrations of $(A)$ dissolved nitrite plus nitrate and ammonium and the $\delta^{15} \mathrm{~N}$ composition of dissolved ammonium, and (B) concentrations of dissolved phosphorus in ground water with depth below the sediment/water interface at McKay Road on November 2, 1992. 
Tabie 6. $\delta^{15} \mathrm{~N}$ compositions of dissolved nitrate in surface water and ground water, and $\delta^{15} \mathrm{~N}$ compositions of solid and dissolved ammonium in surface water and ground water

[NO 3 , nitrate; $\mathrm{NH}_{4}$, ammonium; $\mathrm{NA}$, not applicable; in., inch]

\begin{tabular}{|c|c|c|c|}
\hline $\begin{array}{c}\text { Sample } \\
\text { name }\end{array}$ & Date & $\begin{array}{c}\delta^{15} \mathrm{~N}_{-N O_{3}} \\
\text { dissolvod } \\
\text { (per mll) }\end{array}$ & $\begin{array}{l}\delta^{15} \mathrm{~N}-\mathrm{NH}_{4}, \\
\text { dissolved } \\
\text { or solld } \\
\text { (per mil) }\end{array}$ \\
\hline Metro south outfall & $11 / 11 / 92$ & NA & 9.2 \\
\hline Metro north outfall & 11/11/92 & 7.6 & NA \\
\hline South Platte River at McKay Road & $11 / 02 / 92$ & NA & 14.2 \\
\hline McKay Road-piezometer 1 & $11 / 02 / 92$ & NA & 7.6 \\
\hline McKay Road-piezometer 2 & $11 / 02 / 92$ & NA & 16.6 \\
\hline McKay Road-piezometer 3 & $11 / 02 / 92$ & NA & 20.2 \\
\hline McKay Road-well 2A & $11 / 02 / 92$ & NA & 17.2 \\
\hline McKay Road-well 2B & $11 / 02 / 92$ & NA & 13.0 \\
\hline South Platte River at Road 8 & $11 / 30 / 92$ & 9.1 & NA \\
\hline Road 8-piezometer 1 & $11 / 30 / 92$ & 9.0 & NA \\
\hline Road 8-piezometer 2 & $11 / 30 / 92$ & 8.4 & NA \\
\hline Road 8-well 1A & $11 / 30 / 92$ & 8.4 & NA \\
\hline Road 8-well 1B & $11 / 30 / 92$ & 8.4 & NA \\
\hline $\begin{array}{l}\text { Cross-section site } 6 \text { ground water ( } 12 \text { in. below } \\
\text { sediment/water interface) }\end{array}$ & $12 / 22 / 92$ & NA & 11.3 \\
\hline Cross-section site 6 waterfowl waste (fresh) & $12 / 22 / 92$ & NA & 11.3 \\
\hline Cross-section site 6 waterfowl waste (weathered) & $12 / 22 / 92$ & NA & 15.7 \\
\hline
\end{tabular}

Table 7. Rates of nitrous oxide production measured in laboratory incubations of riverbed and aquifer sediments

$\left[\mathrm{N}_{2} \mathrm{O}\right.$, nitrous oxide; $\mathrm{NO}_{3}$, nitrate; mmol/L, millimoles per liter; $\mathrm{nmol} / \mathrm{gdw} / \mathrm{d}$, nanomoles per gram of dry sediment per day; \pm , plus or minus]

\begin{tabular}{|c|c|c|c|c|c|}
\hline \multirow[b]{2}{*}{$\begin{array}{c}\text { Sample } \\
\text { name }\end{array}$} & \multirow[b]{2}{*}{$\begin{array}{l}\text { Measured } \\
\text { concentration of } \\
\text { dissolved nitrate } \\
\text { (mmoll) }\end{array}$} & \multirow[b]{2}{*}{$\begin{array}{l}\text { Addition of } \\
1 \mathrm{mmolh} \\
\text { glucose }\end{array}$} & \multicolumn{3}{|c|}{$\begin{array}{l}\text { Rate of } \mathrm{N}_{2} \mathrm{O} \text { production at glven } \mathrm{NO}_{3} \text { concentration } \\
\text { (nmolgdw/d) }\end{array}$} \\
\hline & & & $\begin{array}{l}\text { Measured } \\
\text { nitrate } \\
\text { concentration }\end{array}$ & $\begin{array}{l}1 \text { mmoll } \\
\text { dlssolved } \\
\text { nitrate }\end{array}$ & $\begin{array}{l}10 \text { mmoll } \\
\text { dissolved } \\
\text { nltrate }\end{array}$ \\
\hline 88th Avenue riverbed sediment & 0.003 & No & $0 \pm 0$ & $52 \pm 6$ & $400 \pm 29$ \\
\hline 88th Avenue riverbed sediment & .003 & Yes & $0 \pm 0$ & $124 \pm 35$ & $1,483 \pm 232$ \\
\hline McKay Road riverbed sediment & .021 & No & $0 \pm 0$ & $84 \pm 15$ & $214 \pm 13$ \\
\hline McKay Road riverbed sediment & .021 & Yes & $0 \pm 0$ & $336 \pm 43$ & $1,384 \pm 24$ \\
\hline Henderson riverbed sediment & .021 & No & $1 \pm 0$ & $19 \pm 8$ & $122 \pm 14$ \\
\hline Henderson riverbed sediment & .021 & Yes & $0 \pm 0$ & $200 \pm 22$ & $1,034 \pm 237$ \\
\hline Road 8 riverbed sediment & .357 & No & $15 \pm 5$ & $25 \pm 5$ & $28 \pm 7$ \\
\hline Road 8 riverbed sediment & .357 & Yes & $25 \pm 6$ & $271 \pm 41$ & $321 \pm 28$ \\
\hline Henderson aquifer sediment & .214 & No & $3 \pm 1$ & $2 \pm 0$ & $7 \pm 0$ \\
\hline Henderson aquifer sediment & .214 & Yes & $34 \pm 6$ & $22 \pm 9$ & $25 \pm 4$ \\
\hline
\end{tabular}


The presence of sources and sinks of dissolvednitrogen and -phosphorus species in the small-area flow system is important because all of these constituents can contribute indirectly to the depletion of DO in the river by promoting the growth of aquatic vegetation that eventually die and decay, thereby adding an oxygen demand to the river. Aquatic vegetation also decreases DO concentrations in the river when they respire at night. In addition, the oxidation of ammonium to nitrate consumes DO in the river. In general, the widespread distribution of sources and sinks of dissolved nitrite plus nitrate, ammonium, and phosphorus in the small-area flow system makes it difficult to determine how much nitrogen and phosphorus is entering the river from ground-water discharge.

\section{SUMMARY}

Concentrations of DO in reaches of the South Platte River between Denver and Fort Lupton frequently fall below the minimum concentrations established by the Colorado Department of Health and Environment to maintain the health of aquatic life in the river. As a follow-up to preliminary studies conducted by the USGS that indicated that the discharge of anoxic ground water may contribute to low DO concentrations in the river, an assessment was made of the quantity and quality of ground-water discharge to the South Platte River from Denver to Fort Lupton, Colorado. The quantity of ground-water discharge was determined by (1) mass balance of surfacewater inflows and outflows from August 1992 through January 1993 and in May and July 1993, and (2) measurements of ground-water discharge across the sediment/water interface in the river channel from August 1992 through January 1993. Samples of surface water and ground water used for water-quality analyses were collected from August 1992 through January 1993 and in May and July 1993. Specific conductance, $\mathrm{pH}, \mathrm{T}, \mathrm{DO}$, alkalinity, and concentrations of dissolved major ions and nutrients were measured in surface-water samples collected at three locations in the river, in ground-water samples collected from 12 monitoring wells screened in the alluvial aquifer adjacent to the river, and in ground-water samples collected from 9 piezometers screened in riverbed sediments underlying the active river channel. Specific conductance, $\mathrm{pH}, \mathrm{T}$, and DO were measured in surfacewater samples collected at 27 of the 30 cross-section sites in the river. Specific conductance, $\mathrm{pH}, \mathrm{T}, \mathrm{DO}$, and concentrations of dissolved nutrients were measured in ground-water samples collected from an additional 159 temporary wells screened in the riverbed sediments underlying the active channel of the river.
The ground-water flow system was divided into a large-area flow system and a small-area flow system. The precise boundaries of the two flow systems are not known. However, the large-area flow system was considered to incorporate all alluvial sediments in hydrologic connection with the South Platte River. The small-area flow system was considered to incorporate the alluvial aquifer in the vicinity of the river. Flowpath lengths in the large-area system were considered to be on the order of hundreds of feet to more than a mile, whereas flow-path lengths in the small-area system were considered to be on the order of feet to hundreds of feet. The quantity of ground-water discharge from the large-area flow system to the South Platte River was estimated by calculating a mass balance of all measured surface-water inflows and outflows to three reaches of the river (64th Avenue to 88th Avenue, 104th Avenue to upstream from the Brighton Ditch headgate, and 160th Avenue to Highway 52) and by attributing the difference between inflows and outflows to ground-water discharge. Mass-balance estimates of incremental ground-water discharge ranged from -27 to $17\left(\mathrm{ft}^{3} / \mathrm{s}\right) / \mathrm{mi}$ for the three reaches studied; the median rate was $4.6\left(\mathrm{ft}^{3} / \mathrm{s}\right) / \mathrm{mi}$. Incremental groundwater discharge rates determined by mass balance were most variable in the reach extending from 64th to 88th Avenue and were partially related to the amount of effluent being released from the MWRD. There generally was a net addition of water to the river from ground-water discharge when the rate of effiuent discharge was low (for example, September, November, and December 1992 and July 1993), whereas there was a net loss of water from the river to the aquifer when the rate of effiuent discharge was high (for example, August 1992 and January 1993) or when flow in the river upstream from the plant was high (for example, May 1993).

There was less variability in the incremental ground-water discharge rates determined by mass balance in reaches of the river downstream from 88th Avenue than there was in the reach upstream from 88th Avenue, possibly due to increased irrigation return flows from agricultural fields overlying the alluvial aquifer downstream from Denver and to a dampening of discharge fluctuations with distance downstream from the MWRD plant. Median rates of incremental ground-water discharge in the reaches extending from 104th Avenue to upstream from the Brighton Ditch headgate and from 160th Avenue to Highway 52 were within about 10 percent of each other [5.1 and $4.6\left(\mathrm{ft}^{3} / \mathrm{s}\right) / \mathrm{mi}$. The median percentage of flow in the river at the downstream end of each reach from groundwater discharge was 17 percent for the reach extending 
from 104th Avenue to Brighton Ditch Diversion and 11 percent for the reach extending from 160th Avenue to Highway 52. The median percentage for these two reaches combined was 15 percent. Based on these estimates, ground-water discharge between 104th Avenue and Highway 52 would have accounted for a total of about 30 percent of the flow in the river at Highway 52 .

The quantity of ground-water discharge from the small-area flow system to the South Platte River was estimated from direct measurements of incremental discharge made at 30 cross-section sites. Incremental ground-water discharge from the small-area flow system ranged from $-1,360$ to $1,000\left(\mathrm{ft}^{3} / \mathrm{s}\right) / \mathrm{mi}$, with a median value of $-5.8\left(\mathrm{ft}^{3} / \mathrm{s}\right) / \mathrm{mi}$ at the $30 \mathrm{cross}$-section sites. The maximum incremental ground-water discharge rates measured for the small-area flow system are 50 to 60 times higher than previously estimated incremental ground-water discharge rates for this reach of the South Platte River and are higher by a similar magnitude than maximum incremental groundwater discharge rates measured by mass balance in this study. Furthermore, measurements of the large-area flow system indicated that ground water continuously discharged to reaches 2 and 3, whereas measurements of the small-area flow system indicated that surface water recharged the aquifer as frequently as ground water discharged to the river. The reversals in flow direction and the high rates of incremental groundwater discharge from the small-area flow system are plausible if they reflect transient conditions in the flow system. Measurements of river stage and discharge from the MWRD plant indicate that changes in river stage were related to hourly changes in effluentdischarge rates from the MWRD plant. These frequent changes in river stage, although typically less than about $0.25 \mathrm{ft}$, may have provided a stress on the small-area flow system large enough to cause the transient discharge conditions that were measured at the sediment/water interface.

The transient nature of incremental groundwater discharge rates in the small-area flow system were analyzed in a series of 24 hourly measurements of discharge. In general, the rate and direction of water movement from the small-area flow system were related to changes in river stage, with the highest rates of ground-water discharge corresponding to the lowest river stages and the lowest rates of discharge occurring at higher river stages. The data indicate that the smallarea flow system probably provided no net gain or loss of water to the river, but that it was superimposed on the large-area flow system that did provide water to the river [at a median rate of $\left(4.6 \mathrm{ft}^{3} / \mathrm{s}\right) / \mathrm{mi}$ ]. In essence, the small-area flow system represented a zone of mixing between the river and the large-area flow system.

The median value of $\mathrm{pH}$ in water samples from the large-area flow system was 7.16. Values of $\mathrm{pH}$ in water from the large-area flow system generally were lower than values in the river, indicating that the discharge of ground water from the large-area flow system to the river would lower the $\mathrm{pH}$ of river water under conservative mixing conditions. The median concentration of DO in water from the large-area flow system was $0.9 \mathrm{mg} / \mathrm{L}$, which is less than the median instantaneous daytime concentration of DO $(8.4 \mathrm{mg} / \mathrm{L})$ in the river, indicating that the discharge of ground water . from the large-area flow system to the river also would lower DO concentrations in the river water under conservative mixing conditions.

Concentrations of dissolved nitrite plus nitrate, ammonium, and phosphorus in water from the largearea flow system were highly variable between wells at a given site and between sites. In general, concentrations of nitrite plus nitrate were higher in ground water along the downstream river reach than in ground water along the upstream river reach. The opposite concentration distribution was observed for ammonium and phosphorus. The data indicate that ground-water discharge from the large-area flow system may have been a source of nitrite plus nitrate to the downstream river reach and a source of ammonium and phosphorus to the upstream river reach.

The median concentration of DO in water from the small-area flow system was $0.2 \mathrm{mg} / \mathrm{L}$. The DO data indicate that sediments in the small-area flow system were a sink for DO in water discharging from the largearea flow system and for surface water infiltrating into the bed sediments. Organic carbon in water and sediments from the river provided the reduced carbon needed to reduce DO entering the small-area flow system. Even though the small-area flow system provided no net addition of water to the river, it had the capability of lowering DO concentrations in the river as surface water cycled in and out of the sediments in the small-area flow system.

Chemical and isotopic data and laboratory studies indicate that sediments in the small-area flow system were a source of ammonium and phosphorus and a sink for nitrite plus nitrate to water in the small-area flow system. Whether that water was mostly from the large-area flow system or from the river would not matter. Organic-rich sediments in the upstream reach of the river appeared to be a source of ammonium and phosphorus to water in the small-area flow system. These sediments also had a high potential for removing 
nitrite plus nitrate by denitrification from water entering the small-area flow system. Data did not indicate that organic-poor sediments in the downstream river reach were a source of ammonium or phosphorus to the small-area flow system. However, laboratory studies did show that those sediments also had the potential to remove nitrite plus nitrate by denitrification from waters entering the small-area flow system in the downstream river reach. In general, the widespread distribution of sources and sinks of dissolved nitrite plus nitrate, ammonium, and phosphorus in the smallarea flow system makes it difficult to determine how much nitrogen and phosphorus is entering the river from ground-water discharge.

\section{REFERENCES CITED}

Bowles, J.E., 1978, Engineering properties of soils and their measurement: New York, McGraw-Hill Book Company, 213 p.

Bradley, P.M., Aelion, C.M., and Vroblesky, D.A., 1992, Influence of environmental factors on denitrification in sediment contaminated with JP-4 jet fuel: Ground Water, v. 30, p. 843-848.

Buchanan, T.J., and Somers, W.P., 1969, Discharge measurements at gaging stations: U.S. Geological Survey Techniques of Water-Resources Investigations, book 3, chap. A8, 65 p.

Camp Dresser and McKee, Inc., 1992, Nitrification alternatives study: Report to Metro Wastewater Reclamation District, 142 p.
Colorado Department of Health and Environment, 1993, Classifications and numeric standards for the South Platte River Basin, Laramie River Basin, Republican River Basin, and Smoky Hill River Basin: WaterQuality Control Commission 5 CCR 1002-8.

Gaggiani, N.G., Britton, L.J., and Minges, D.R., 1987, Hydrology of Area 59, Northern Great Plains and Rocky Mountain Coal Provinces, Colorado and Wyoming: U.S. Geological Survey Open-File Report 85-153, 124 p.

Hurr, T.R., and Schneider, P.A., Jr., 1972, Hydrogeologic characteristics of the valley-fill aquifer in the Brighton Reach of the South Platte River Valley, Colorado: U.S. Geological Survey Open-File Report, 2 p.

Wershaw, R.L., Fishman, M.J., Grabbe, R.R., and Lowe, L.E., 1987, Methods for the determination of organic substances in water and fluvial sediments: U.S. Geological Survey Techniques of WaterResources Investigations, book 5, chap. A3, 80 p.

White, D.S., 1993, Perspectives on defining and delineating the hyporheic zones: Journal of the North American Benthological Society, v. 12, p. 61-69.

Winter, T.C., LaBaugh, J.W., and Rosenberry, D.O., 1988, The design and use of a hydraulic potentiomanometer for direct measurement of differences in hydraulic head between ground water and surface water: Limnology and Oceanography, v. 33, p. 1209-1214. 


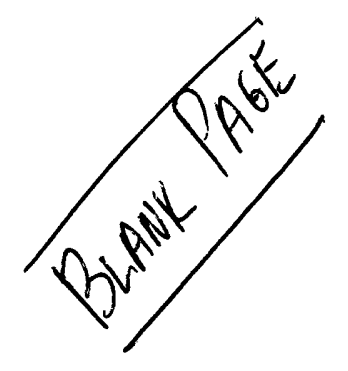




\section{HYDROLOGIC AND WATER-QUALITY DATA}


Table 8. Discharge at selected surface-water sites on selected dates

$\left[\mathrm{ft}^{3} / \mathrm{s}\right.$, cubic foot per second]

\begin{tabular}{|c|c|c|c|}
\hline Reach & Site of measurement & Date & $\begin{array}{c}\text { Discharge } \\
\left(\mathrm{ft}^{3} / \mathrm{s}\right)\end{array}$ \\
\hline \multirow[t]{7}{*}{1} & South Platte River at 64th Avenue & $08 / 28 / 92$ & 19.3 \\
\hline & & $09 / 23 / 92$ & 25.5 \\
\hline & & $11 / 02 / 92$ & 11.7 \\
\hline & & $12 / 02 / 92$ & 16.7 \\
\hline & & $01 / 19 / 93$ & 28.7 \\
\hline & & $05 / 19 / 93$ & 564 \\
\hline & & $07 / 27 / 93$ & 6.80 \\
\hline \multirow[t]{7}{*}{1} & Metro Wastewater Reclamation District Plant & $08 / 28 / 92$ & 322 \\
\hline & & $09 / 23 / 92$ & 191 \\
\hline & & $11 / 02 / 92$ & 167 \\
\hline & & $12 / 02 / 92$ & 93.2 \\
\hline & & $01 / 19 / 93$ & 272 \\
\hline & & $05 / 19 / 93$ & 115 \\
\hline & & $07 / 27 / 93$ & 122 \\
\hline \multirow[t]{7}{*}{1} & Sand Creek at mouth near Commerce City & $08 / 28 / 92$ & 23.7 \\
\hline & & $09 / 23 / 92$ & 17.7 \\
\hline & & $11 / 02 / 92$ & 21.3 \\
\hline & & $12 / 02 / 92$ & 22.9 \\
\hline & & $01 / 19 / 93$ & 17.3 \\
\hline & & $05 / 19 / 93$ & 44.4 \\
\hline & & $07 / 27 / 93$ & 98.0 \\
\hline \multirow[t]{7}{*}{1} & Clear Creek at Derby & $08 / 28 / 92$ & 20.9 \\
\hline & & $09 / 23 / 92$ & 4.62 \\
\hline & & $11 / 02 / 92$ & 2.26 \\
\hline & & $12 / 02 / 92$ & 9.69 \\
\hline & & $01 / 19 / 93$ & 21.2 \\
\hline & & $05 / 19 / 93$ & 42.0 \\
\hline & & $07 / 27 / 93$ & 126 \\
\hline \multirow[t]{7}{*}{1} & Niver Creek at mouth & $08 / 28 / 92$ & 2.46 \\
\hline & & $09 / 23 / 92$ & .89 \\
\hline & & $11 / 02 / 92$ & 4.69 \\
\hline & & $12 / 02 / 92$ & .88 \\
\hline & & $01 / 19 / 93$ & .91 \\
\hline & & $05 / 19 / 93$ & 9.34 \\
\hline & & $07 / 27 / 93$ & 1.72 \\
\hline
\end{tabular}


Table 8. Discharge at selected surface-water sites on selected dates--Continued

\begin{tabular}{|c|c|c|c|}
\hline Reach & Site of measurement & Date & $\begin{array}{c}\text { Discharge } \\
\left(\mathrm{ft}^{3} / \mathrm{s}\right)\end{array}$ \\
\hline \multirow[t]{7}{*}{1} & Miscellaneous discharges & $08 / 28 / 92$ & 0.44 \\
\hline & & $09 / 23 / 92$ & .60 \\
\hline & & $11 / 02 / 92$ & 0 \\
\hline & & $12 / 02 / 92$ & 0 \\
\hline & & $01 / 19 / 93$ & 0 \\
\hline & & $05 / 19 / 93$ & 23.1 \\
\hline & & $07 / 27 / 93$ & .36 \\
\hline \multirow[t]{6}{*}{1} & South Platte River at 88 th Avenue & $08 / 28 / 92$ & 380 \\
\hline & & $11 / 02 / 92$ & 259 \\
\hline & & $12 / 02 / 92$ & 154 \\
\hline & & $01 / 19 / 93$ & 245 \\
\hline & & $05 / 19 / 93$ & 710 \\
\hline & & $07 / 27 / 93$ & 405 \\
\hline 1 & South Platte River at McKay Road & $09 / 23 / 92$ & 318 \\
\hline \multirow[t]{6}{*}{2} & South Platte River at 104th Avenue & $09 / 28 / 92$ & 121 \\
\hline & & $10 / 30 / 92$ & 153 \\
\hline & & $12 / 01 / 92$ & 202 \\
\hline & & $01 / 15 / 93$ & 179 \\
\hline & & $05 / 17 / 93$ & 364 \\
\hline & & $07 / 28 / 93$ & 310 \\
\hline \multirow[t]{6}{*}{2} & Brantner Ditch at headgate & $09 / 28 / 92$ & 26.0 \\
\hline & & $10 / 30 / 92$ & 2.87 \\
\hline & & $12 / 01 / 92$ & 0 \\
\hline & & $01 / 15 / 93$ & $\mathbf{0}$ \\
\hline & & $05 / 17 / 93$ & 45.2 \\
\hline & & $07 / 28 / 93$ & 37.0 \\
\hline \multirow[t]{6}{*}{2} & Miscellaneous discharges & $09 / 28 / 92$ & 6.38 \\
\hline & & $10 / 30 / 92$ & 3.98 \\
\hline & & $12 / 01 / 92$ & 10.0 \\
\hline & & $01 / 15 / 93$ & 13.2 \\
\hline & & $05 / 17 / 93$ & 2.00 \\
\hline & & $07 / 28 / 93$ & 5.00 \\
\hline \multirow[t]{6}{*}{2} & South Platte River upstream from the Brighton Ditch headgate & $09 / 28 / 92$ & 139 \\
\hline & & $10 / 30 / 92$ & 178 \\
\hline & & $12 / 01 / 92$ & 273 \\
\hline & & $01 / 15 / 93$ & 226 \\
\hline & & $05 / 17 / 93$ & 369 \\
\hline & & 07/28/93 & 342 \\
\hline
\end{tabular}


Table 8. Discharge at selected surface-water sites on selected dates--Continued

\begin{tabular}{|c|c|c|c|}
\hline Reach & Site of measurement & Date & $\begin{array}{c}\text { Discharge } \\
\left(\mathrm{ft}^{3} / \mathrm{s}\right)\end{array}$ \\
\hline \multirow[t]{7}{*}{3} & South Platte River at 160th Avenue & $08 / 27 / 92$ & 388 \\
\hline & & $09 / 24 / 92$ & 162 \\
\hline & & $10 / 29 / 92$ & 203 \\
\hline & & $11 / 30 / 92$ & 324 \\
\hline & & $01 / 14 / 93$ & 218 \\
\hline & & $05 / 25 / 93$ & 317 \\
\hline & & $07 / 29 / 93$ & 319 \\
\hline \multirow[t]{7}{*}{3} & City of Brighton wastewater-treatment plant & $08 / 27 / 92$ & 2.49 \\
\hline & & $09 / 24 / 92$ & 2.28 \\
\hline & & $10 / 29 / 92$ & 1.68 \\
\hline & & $11 / 30 / 92$ & 1.77 \\
\hline & & $01 / 14 / 93$ & 1.79 \\
\hline & & $05 / 25 / 93$ & 2.00 \\
\hline & & $07 / 29 / 93$ & 2.10 \\
\hline \multirow[t]{7}{*}{3} & Lupton Bottoms Ditch at headgate & $08 / 27 / 92$ & 11.7 \\
\hline & & $09 / 24 / 92$ & 31.7 \\
\hline & & $10 / 29 / 92$ & 0 \\
\hline & & $11 / 30 / 92$ & $\mathbf{0}$ \\
\hline & & $01 / 14 / 93$ & $\mathbf{0}$ \\
\hline & & $05 / 25 / 93$ & 53.5 \\
\hline & & $07 / 29 / 93$ & 62.0 \\
\hline \multirow[t]{7}{*}{3} & Big Dry Creek at mouth & $08 / 27 / 92$ & 80.2 \\
\hline & & $09 / 24 / 92$ & 57.8 \\
\hline & & $10 / 29 / 92$ & 33.0 \\
\hline & & $11 / 30 / 92$ & 23.8 \\
\hline & & $01 / 14 / 93$ & 16.5 \\
\hline & & $05 / 25 / 93$ & 27.2 \\
\hline & & $07 / 29 / 93$ & 34.0 \\
\hline \multirow[t]{7}{*}{3} & South Platte River at Highway 52 & $08 / 27 / 92$ & 593 \\
\hline & & $09 / 24 / 92$ & 233 \\
\hline & & $10 / 29 / 92$ & 285 \\
\hline & & $11 / 30 / 92$ & 399 \\
\hline & & $01 / 14 / 93$ & 257 \\
\hline & & $05 / 25 / 93$ & 318 \\
\hline & & $07 / 29 / 93$ & 320 \\
\hline
\end{tabular}


Table 9. Rates of ground-water discharge across the sediment/water interface and quality of surface water and ground water 1 foot below the sediment/water interface at cross-section sites

$\left[\left(\mathrm{ft}^{3} / \mathrm{s}\right) / \mathrm{mi}\right.$, cubic foot per second per mile; $\mu \mathrm{S} / \mathrm{cm}$, microsiemens per centimeter at $25^{\circ} \mathrm{C} ;{ }^{\circ} \mathrm{C}$, degree Celsius; NA, not applicable; --, missing data; $\mathrm{mg} / \mathrm{L}$, milligram per liter; <, less than]

\begin{tabular}{|c|c|c|c|c|c|c|}
\hline $\begin{array}{l}\text { Cross-section } \\
\text { number }\end{array}$ & Date & $\begin{array}{c}\text { Incremental } \\
\text { ground-water } \\
\text { dlscharge rate } \\
{\left[\left(\mathrm{ft}^{3} / \mathrm{s}\right) / \mathrm{mi}\right]}\end{array}$ & $\begin{array}{c}\text { Specific } \\
\text { conductance of } \\
\text { surface water } \\
(\mu \mathrm{S} / \mathrm{cm})\end{array}$ & $\begin{array}{c}\text { Specific } \\
\text { conductance of } \\
\text { ground water } \\
(\mu \mathrm{S} / \mathrm{cm})\end{array}$ & $\begin{array}{c}\text { pH of } \\
\text { surface water }\end{array}$ & $\begin{array}{c}\mathrm{pH} \text { of } \\
\text { ground water }\end{array}$ \\
\hline 1 & $08 / 17 / 92$ & 14.8 & 751 & 619 & 7.86 & 7.48 \\
\hline 1 & $09 / 01 / 92$ & -20.1 & 1,330 & NA & 7.40 & NA \\
\hline 1 & $10 / 08 / 92$ & -8.98 & 1,360 & 1,030 & 7.68 & 7.48 \\
\hline 1 & $11 / 04 / 92$ & -31.7 & 1,240 & NA & 7.66 & NA \\
\hline 1 & $12 / 15 / 92$ & -13.7 & 1,700 & 1,350 & 7.43 & 7.41 \\
\hline 2 & $09 / 01 / 92$ & 95.0 & 1,010 & 1,020 & 7.02 & 7.04 \\
\hline 2 & $10 / 20 / 92$ & -58.1 & 1,040 & 1,030 & 7.14 & 7.03 \\
\hline 2 & $11 / 04 / 92$ & -1.06 & 1,040 & NA & 7.12 & NA \\
\hline 2 & $12 / 15 / 92$ & 60.2 & 1,120 & 1,060 & 7.28 & 7.29 \\
\hline 3 & $09 / 03 / 92$ & -5.81 & 948 & 915 & 7.40 & 7.12 \\
\hline 3 & $10 / 20 / 92$ & 37.0 & 1,000 & 1,010 & 7.21 & 7.06 \\
\hline 3 & $11 / 05 / 92$ & 2.11 & 1,030 & 873 & 7.30 & 7.53 \\
\hline 3 & $12 / 27 / 92$ & -245 & 1,050 & NA & 7.36 & NA \\
\hline 4 & $08 / 17 / 92$ & 33.3 & 824 & 787 & 7.39 & 7.32 \\
\hline 4 & $09 / 03 / 92$ & 28.0 & 975 & 870 & 7.19 & 7.25 \\
\hline 4 & $10 / 28 / 92$ & -38.5 & 1,080 & NA & 7.14 & NA \\
\hline 4 & $11 / 10 / 92$ & -898 & 1,080 & 1,080 & 7.33 & 7.21 \\
\hline 4 & $12 / 11 / 92$ & -26.9 & 1,090 & 935 & 7.08 & 8.13 \\
\hline 5 & 09/08/92 & 106 & 1,050 & 1,020 & 7.45 & 7.29 \\
\hline 5 & $10 / 26 / 92$ & -7.92 & 1,030 & NA & 7.35 & NA \\
\hline 5 & $11 / 05 / 92$ & -470 & 1,050 & NA & 7.20 & NA \\
\hline 5 & $12 / 10 / 92$ & 174 & 1,040 & 1,090 & 8.26 & 7.08 \\
\hline 6 & $08 / 18 / 92$ & 12.1 & 747 & 1,060 & 7.37 & 6.71 \\
\hline 6 & 09/08/92 & 63.4 & -- & 960 & -. & 7.07 \\
\hline 6 & $10 / 26 / 92$ & -444 & 963 & NA & 7.07 & NA \\
\hline 6 & $11 / 04 / 92$ & -581 & 1,060 & NA & 7.31 & NA \\
\hline 6 & $12 / 22 / 92$ & -288 & 1,110 & 1,080 & 7.40 & 7.16 \\
\hline 7 & $09 / 10 / 92$ & -45.4 & 1,060 & NA & 7.45 & NA \\
\hline 7 & $10 / 27 / 92$ & -13.2 & 1,110 & NA & 7.28 & NA \\
\hline 7 & $11 / 10 / 92$ & -10.6 & 1,040 & NA & 7.33 & NA \\
\hline 7 & $01 / 25 / 93$ & $-1,360$ & 1,020 & 1,030 & 7.84 & 7.52 \\
\hline 8 & 09/10/92 & -290 & 1,020 & 1,040 & 7.52 & 7.30 \\
\hline 8 & $10 / 28 / 92$ & -253 & 1,080 & NA & 7.19 & NA \\
\hline 8 & $11 / 12 / 92$ & -174 & 1,110 & NA & 7.75 & NA \\
\hline 10 & $10 / 27 / 92$ & -16.9 & 1,030 & NA & 7.80 & NA \\
\hline 10 & $11 / 13 / 92$ & -15.3 & 1,110 & NA & 7.72 & NA \\
\hline 10 & $12 / 10 / 92$ & -200 & 1,200 & NA & 7.38 & NA \\
\hline 11 & $09 / 21 / 92$ & 20.1 & 995 & 1,040 & 7.45 & 7.27 \\
\hline 11 & $10 / 14 / 92$ & 142 & 1,040 & 1,010 & 7.39 & 7.20 \\
\hline
\end{tabular}


Table 9. Rates of ground-water discharge across the sediment/water interface and quality of surface water and ground water 1 foot below the sediment/water interface at cross-section sites--Continued

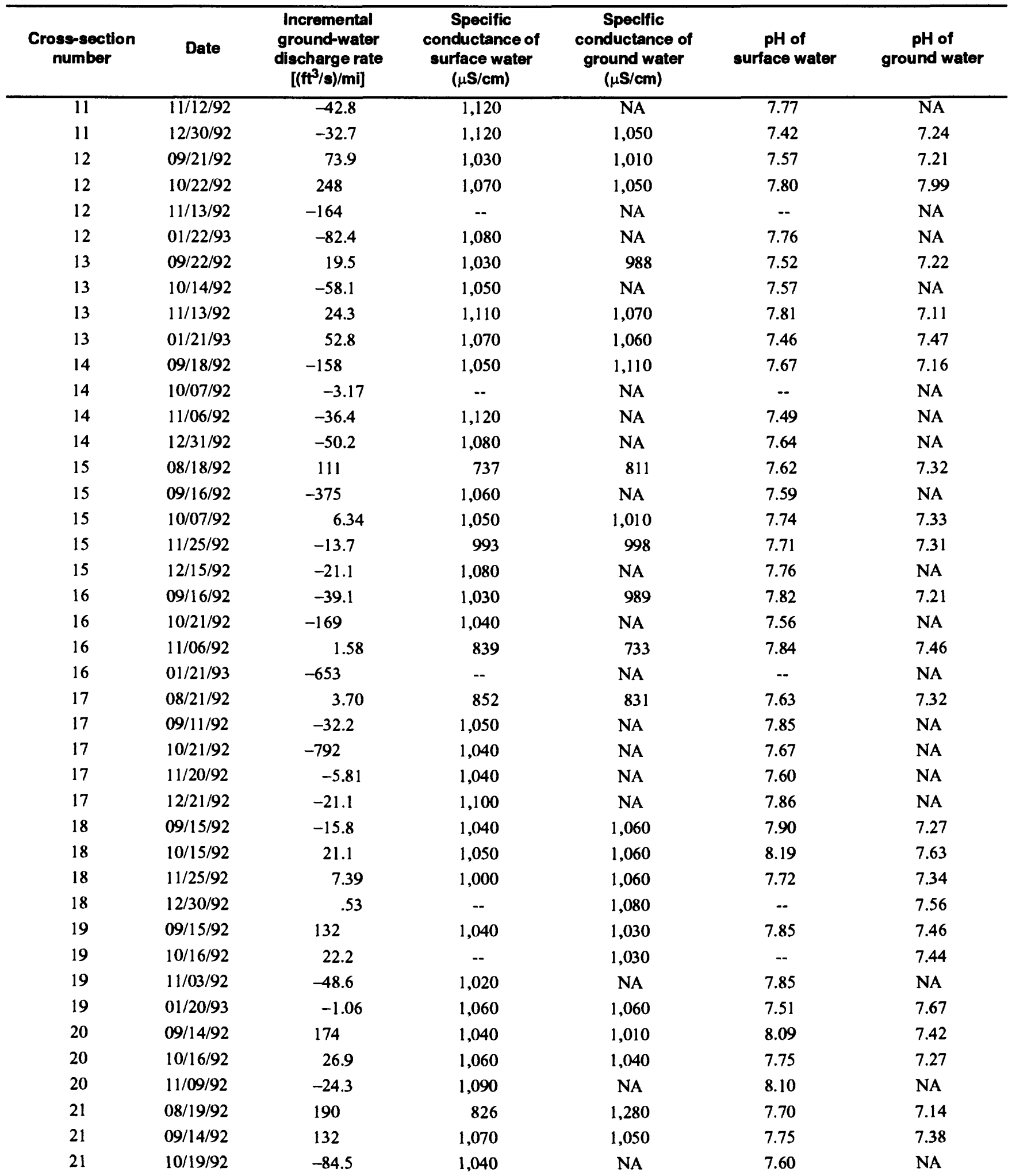


Table 9. Rates of ground-water discharge across the sediment/water interface and quality of surface water and ground water 1 foot below the sediment/water interface at cross-section sites--Continued

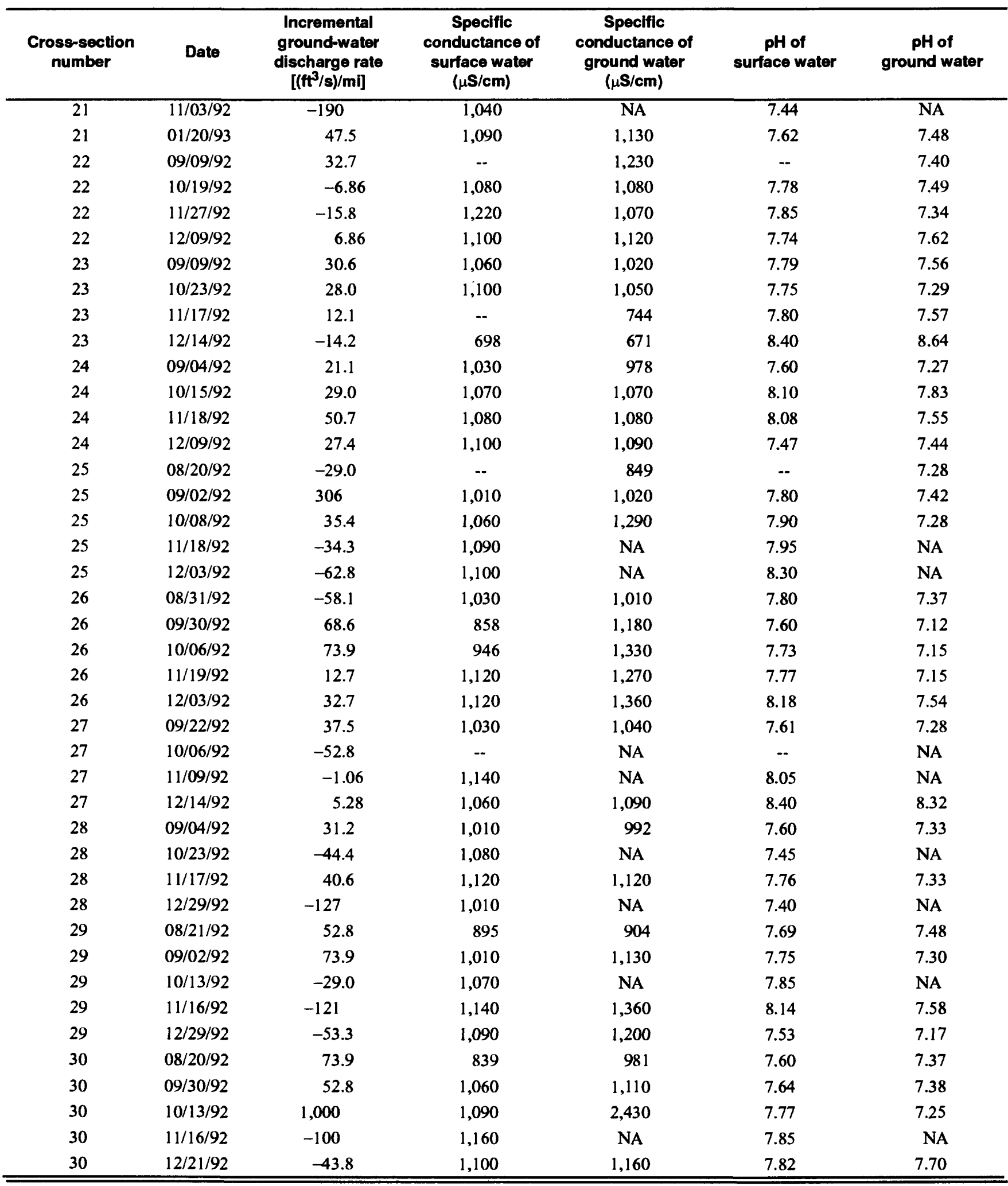


Table 9. Rates of ground-water discharge across the sediment/water interface and quality of surface water and ground water 1 foot below the sediment/water interface at cross-section sites--Continued

\begin{tabular}{|c|c|c|c|c|c|c|c|}
\hline $\begin{array}{l}\text { Cross-section } \\
\text { number }\end{array}$ & Date & $\begin{array}{l}\text { Temperature of } \\
\text { surface water } \\
\left({ }^{\circ} \mathrm{C}\right)\end{array}$ & $\begin{array}{l}\text { Temperature of } \\
\text { ground water } \\
\left.\text { ( }{ }^{\circ} \mathrm{C}\right)\end{array}$ & $\begin{array}{l}\text { Dlesolved } \\
\text { oxygen In } \\
\text { surface water } \\
\text { (mg/L) }\end{array}$ & $\begin{array}{c}\text { Diseolved } \\
\text { oxygen In } \\
\text { ground water } \\
\text { (mg/L) }\end{array}$ & $\begin{array}{l}\text { Nitrite In } \\
\text { ground water, } \\
\text { dissolved } \\
\left(\mathrm{NO}_{2}\right. \\
\text { as } \mathrm{N}, \mathrm{mg} / \mathrm{L})\end{array}$ & $\begin{array}{l}\text { Nitrite plus } \\
\text { nltrate In } \\
\text { ground water, } \\
\text { dissolved } \\
\text { ( } \mathrm{NO}_{2}+\mathrm{NO}_{3} \\
\text { as } \mathrm{N}, \mathrm{mg} / \mathrm{L})\end{array}$ \\
\hline 1 & $08 / 17 / 92$ & 19.7 & 20.3 & 6.5 & $\overline{0.6}$ & -- & $\overline{0.09}$ \\
\hline 1 & 09/01/92 & 18.4 & NA & 7.4 & NA & NA & NA \\
\hline 1 & $10 / 08 / 92$ & 15.3 & 12.8 & 7.0 & .2 & $<0.01$ & 1.65 \\
\hline 1 & $11 / 04 / 92$ & 9.4 & NA & 9.2 & NA & NA & NA \\
\hline 1 & $12 / 15 / 92$ & 7.5 & 5.2 & 8.1 & .5 & $<.01$ & 3.45 \\
\hline 2 & 09/01/92 & 21.9 & 21.4 & 5.7 & .6 & .08 & 1.86 \\
\hline 2 & $10 / 20 / 92$ & 18.7 & 18.4 & 5.9 & .1 & $<.01$ & .02 \\
\hline 2 & $11 / 04 / 92$ & 17.1 & NA & 7.4 & NA & NA & NA \\
\hline 2 & $12 / 15 / 92$ & 14.0 & 13.8 & 6.6 & .4 & .04 & .21 \\
\hline 3 & 09/03/92 & 20.5 & 20.3 & 6.9 & .2 & .04 & .83 \\
\hline 3 & $10 / 20 / 92$ & 20.0 & 19.6 & 6.5 & .4 & $<.01$ & .06 \\
\hline 3 & $11 / 05 / 92$ & 15.9 & 16.5 & 6.8 & .3 & $<.01$ & .07 \\
\hline 3 & $12 / 27 / 92$ & 11.7 & NA & 6.7 & NA & NA & NA \\
\hline 4 & $08 / 17 / 92$ & 21.3 & 20.4 & 4.6 & .5 & -- & .36 \\
\hline 4 & 09/03/92 & 22.4 & 20.1 & 5.8 & .1 & $<.01$ & .05 \\
\hline 4 & $10 / 28 / 92$ & 18.3 & NA & 6.1 & NA & NA & NA \\
\hline 4 & $11 / 10 / 92$ & 15.2 & 14.5 & 6.2 & .2 & .08 & 1.47 \\
\hline 4 & $12 / 11 / 92$ & 12.9 & 15.2 & 6.7 & .6 & $<.01$ & .06 \\
\hline 5 & 09/08/92 & 19.2 & 20.6 & 6.7 & .1 & .07 & .59 \\
\hline 5 & $10 / 26 / 92$ & 18.2 & NA & 5.4 & NA & NA & NA \\
\hline 5 & $11 / 05 / 92$ & 14.7 & NA & 9.1 & NA & NA & NA \\
\hline 5 & $12 / 10 / 92$ & 13.8 & 11.8 & 7.5 & 1.1 & $<.01$ & .11 \\
\hline 6 & $08 / 18 / 92$ & -- & 21.2 & 5.3 & .5 & -- & .29 \\
\hline 6 & $09 / 08 / 92$ &.- & 21.4 & - & .2 & $<.01$ & $<.01$ \\
\hline 6 & $10 / 26 / 92$ & 20.9 & NA & 7.0 & NA & NA & NA \\
\hline 6 & $11 / 04 / 92$ & 12.5 & NA & 6.6 & NA & NA & NA \\
\hline 6 & $12 / 22 / 92$ & 11.4 & 11.4 & 6.2 & .2 & $<.01$ & .11 \\
\hline 7 & $09 / 10 / 92$ & 18.7 & NA & 6.6 & NA & NA & NA \\
\hline 7 & $10 / 27 / 92$ & 20.8 & NA & 6.5 & NA & NA & NA \\
\hline 7 & $11 / 10 / 92$ & 15.4 & NA & 5.3 & NA & NA & NA \\
\hline 7 & $01 / 25 / 93$ & 8.8 & 8.7 & 4.2 & .6 & $<.01$ & .14 \\
\hline 8 & $09 / 10 / 92$ & 22.4 & 20.4 & 7.6 & .3 & .04 & .25 \\
\hline 8 & $10 / 28 / 92$ & 18.2 & NA & 7.0 & NA & NA & NA \\
\hline 8 & $11 / 12 / 92$ & 13.0 & NA & 6.2 & NA & NA & NA \\
\hline 10 & $10 / 27 / 92$ & 18.1 & NA & 8.5 & NA & NA & NA \\
\hline 10 & $11 / 13 / 92$ & 12.3 & NA & 7.2 & NA & NA & NA \\
\hline 10 & $12 / 10 / 92$ & 9.6 & NA & 7.5 & NA & NA & NA \\
\hline 11 & $09 / 21 / 92$ & 19.8 & 19.2 & 6.3 & .2 & .04 & .67 \\
\hline 11 & $10 / 14 / 92$ & 16.0 & 17.5 & 4.7 & .1 & .02 & .30 \\
\hline 11 & $11 / 12 / 92$ & 10.6 & NA & 6.5 & NA & NA & NA \\
\hline 11 & $12 / 30 / 92$ & 8.9 & 9.3 & 7.1 & $<.1$ & $<.01$ & .10 \\
\hline
\end{tabular}


Table 9. Rates of ground-water discharge across the sediment/water interface and quality of surface water and ground water 1 foot below the sediment/water interface at cross-section sites--Continued

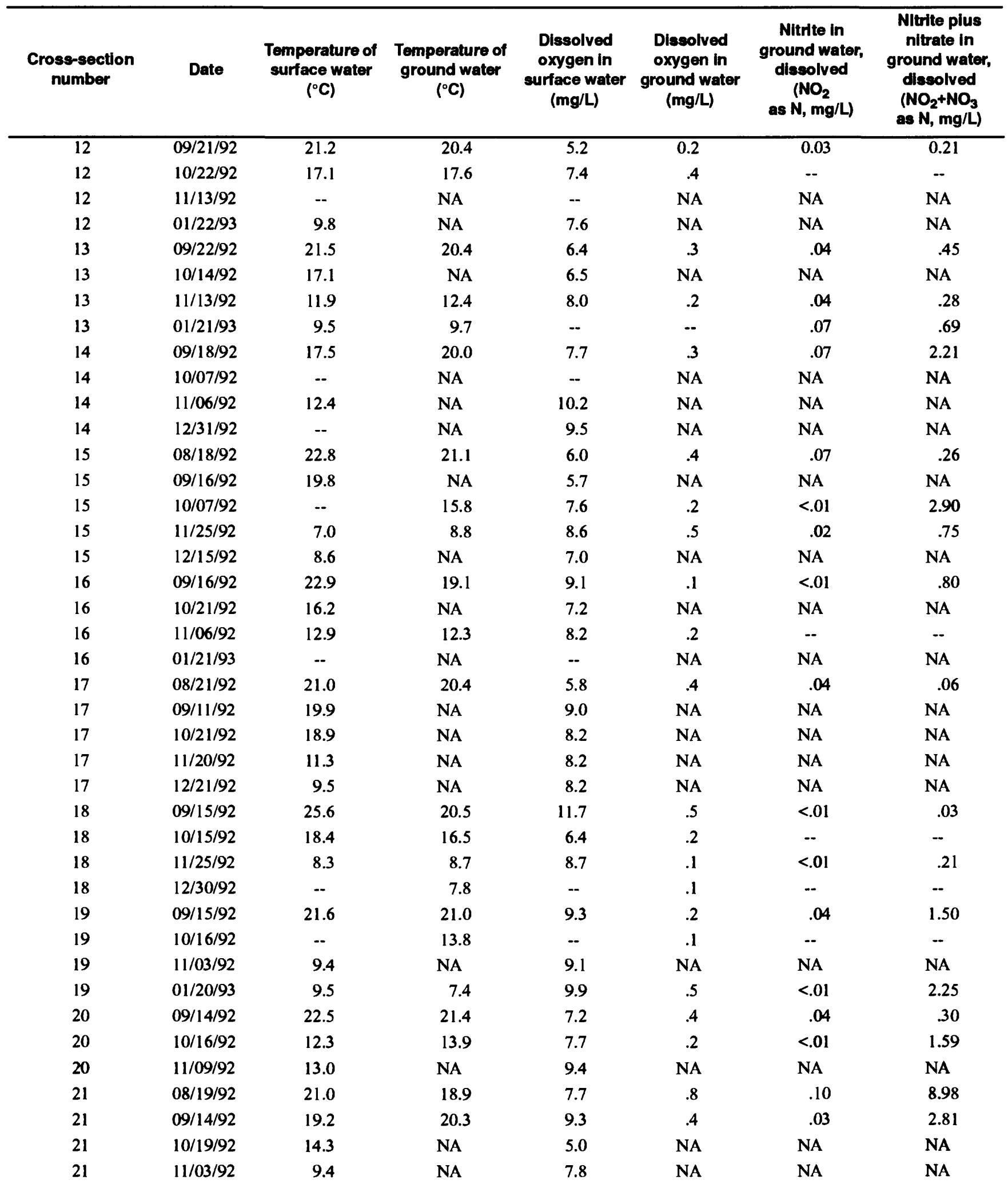


Tabie 9. Rates of ground-water discharge across the sediment/water interface and quality of surface water and ground water 1 foot below the sediment/water interface at cross-section sites--Continued

\begin{tabular}{|c|c|c|c|c|c|c|c|}
\hline $\begin{array}{l}\text { Cross-section } \\
\text { number }\end{array}$ & Date & $\begin{array}{c}\text { Temperature of } \\
\text { surface water } \\
\left({ }^{\circ} \mathrm{C}\right)\end{array}$ & $\begin{array}{l}\text { Temperature of } \\
\text { ground water } \\
\left({ }^{\circ} \mathrm{C}\right)\end{array}$ & $\begin{array}{l}\text { Dissolved } \\
\text { oxygen in } \\
\text { surface water } \\
\text { (mg/L) }\end{array}$ & $\begin{array}{l}\text { Dissolved } \\
\text { oxygen in } \\
\text { ground water } \\
\text { (mg/L) }\end{array}$ & $\begin{array}{l}\text { Nitrtte in } \\
\text { ground water, } \\
\text { dissolved } \\
\left(\mathrm{NO}_{2}\right. \\
\text { as } \mathrm{N}, \mathrm{mg} / \mathrm{L})\end{array}$ & $\begin{array}{l}\text { Nitrite plus } \\
\text { nitrate in } \\
\text { ground water, } \\
\text { dissolved } \\
\text { (NO }_{2}+\mathrm{NO}_{3} \\
\text { as } \mathrm{N}, \mathrm{mg} / \mathrm{L})\end{array}$ \\
\hline 21 & $01 / 20 / 93$ & 7.1 & 7.0 & 7.6 & 1.7 & 0.05 & 1.73 \\
\hline 22 & 09/09/92 & -- & 17.9 & -- & .2 & .04 & .61 \\
\hline 22 & $10 / 19 / 92$ & 16.2 & 15.9 & 8.2 & .1 & .03 & 1.69 \\
\hline 22 & $11 / 27 / 92$ & 6.3 & 8.1 & 12.0 & .5 & $<.01$ & .02 \\
\hline 22 & $12 / 09 / 92$ & 9.2 & 8.1 & 7.1 & .2 & $<.01$ & .06 \\
\hline 23 & $09 / 09 / 92$ & 17.6 & 19.0 & 6.5 & .3 & .05 & 3.90 \\
\hline 23 & $10 / 23 / 92$ & 16.4 & 16.2 & 7.6 & .2 & -- & -- \\
\hline 23 & $11 / 17 / 92$ & 12.5 & 11.3 & 7.8 & 1.0 & .06 & 4.36 \\
\hline 23 & $12 / 14 / 92$ & 7.6 & 6.6 & 8.4 & .2 & $<.01$ & 1.48 \\
\hline 24 & $09 / 04 / 92$ & 20.4 & 19.9 & 5.0 & .3 & .14 & 2.18 \\
\hline 24 & $10 / 15 / 92$ & 15.4 & 16.3 & 7.3 & .1 & $<.01$ & 1.62 \\
\hline 24 & $11 / 18 / 92$ & 11.6 & 10.2 & 10.9 & .1 & $<.01$ & .69 \\
\hline 24 & $12 / 09 / 92$ & 7.1 & 7.1 & 8.5 & .4 & $<.01$ & 1.26 \\
\hline 25 & $08 / 20 / 92$ & -- & 20.8 & - & .2 & .27 & 1.29 \\
\hline 25 & $09 / 02 / 92$ & 21.5 & 18.8 & 4.8 & .1 & .06 & 3.98 \\
\hline 25 & $10 / 08 / 92$ & 10.9 & 13.3 & 6.0 & .3 & -- & -- \\
\hline 25 & $11 / 18 / 92$ & 11.1 & NA & 7.7 & NA & NA & NA \\
\hline 25 & $12 / 03 / 92$ & 6.1 & NA & 7.2 & NA & NA & NA \\
\hline 26 & $08 / 31 / 92$ & 21.8 & 18.0 & 4.8 & .3 & .14 & 4.98 \\
\hline 26 & 09/30/92 & 24.5 & 20.1 & 5.2 & .7 & $<.01$ & 1.79 \\
\hline 26 & $10 / 06 / 92$ & 17.5 & 16.0 & -- & -- & $<.01$ & 3.41 \\
\hline 26 & $11 / 19 / 92$ & 9.4 & 10.4 & 4.0 & .1 & .20 & 3.61 \\
\hline 26 & $12 / 03 / 92$ & 6.1 & 7.4 & 7.4 & .5 & .06 & 3.57 \\
\hline 27 & $09 / 22 / 92$ & 17.4 & 17.9 & 7.6 & .2 & .05 & 1.98 \\
\hline 27 & $10 / 06 / 92$ & -- & NA & -- & NA & NA & NA \\
\hline 27 & $11 / 09 / 92$ & 10.0 & NA & 8.0 & NA & NA & NA \\
\hline 27 & $12 / 14 / 92$ & 5.8 & 6.3 & 10.9 & .5 & .02 & 1.92 \\
\hline 28 & $09 / 04 / 92$ & 18.5 & 19.1 & 4.7 & .2 & $<.01$ & .06 \\
\hline 28 & $10 / 23 / 92$ & 15.4 & NA & 5.8 & NA & NA & NA \\
\hline 28 & $11 / 17 / 92$ & 10.5 & 10.5 & 8.6 & .3 & $<.01$ & 4.88 \\
\hline 28 & $12 / 29 / 92$ & 6.8 & NA & 10.8 & NA & NA & NA \\
\hline 29 & $08 / 21 / 92$ & 25.5 & 20.4 & 5.0 & .3 & $<.01$ & 1.30 \\
\hline 29 & $09 / 02 / 92$ & 18.9 & 17.1 & 5.2 & .1 & $<.01$ & 1.27 \\
\hline 29 & $10 / 13 / 92$ & 16.9 & NA & 5.9 & NA & NA & NA \\
\hline 29 & $11 / 16 / 92$ & 11.7 & 12.3 & 8.7 & .2 & .08 & 1.22 \\
\hline 29 & $12 / 29 / 92$ & 5.7 & 7.3 & 9.0 & .3 & $<.01$ & 3.07 \\
\hline 30 & $08 / 20 / 92$ & 24.3 & 20.2 & 4.3 & .2 & .31 & -- \\
\hline 30 & 09/30/92 & 18.5 & 18.0 & 5.4 & .2 & .13 & 4.29 \\
\hline 30 & $10 / 13 / 92$ & 14.9 & 15.2 & 6.4 & .2 & .19 & 5.63 \\
\hline 30 & $11 / 16 / 92$ & 9.3 & NA & 7.6 & NA & NA & NA \\
\hline 30 & $12 / 21 / 92$ & 5.2 & 6.2 & 7.8 & .4 & .07 & 3.78 \\
\hline
\end{tabular}


Tabie 9. Rates of ground-water discharge across the sediment/water interface and quality of surface water and ground water 1 foot below the sediment/water interface at cross-section sites--Continued

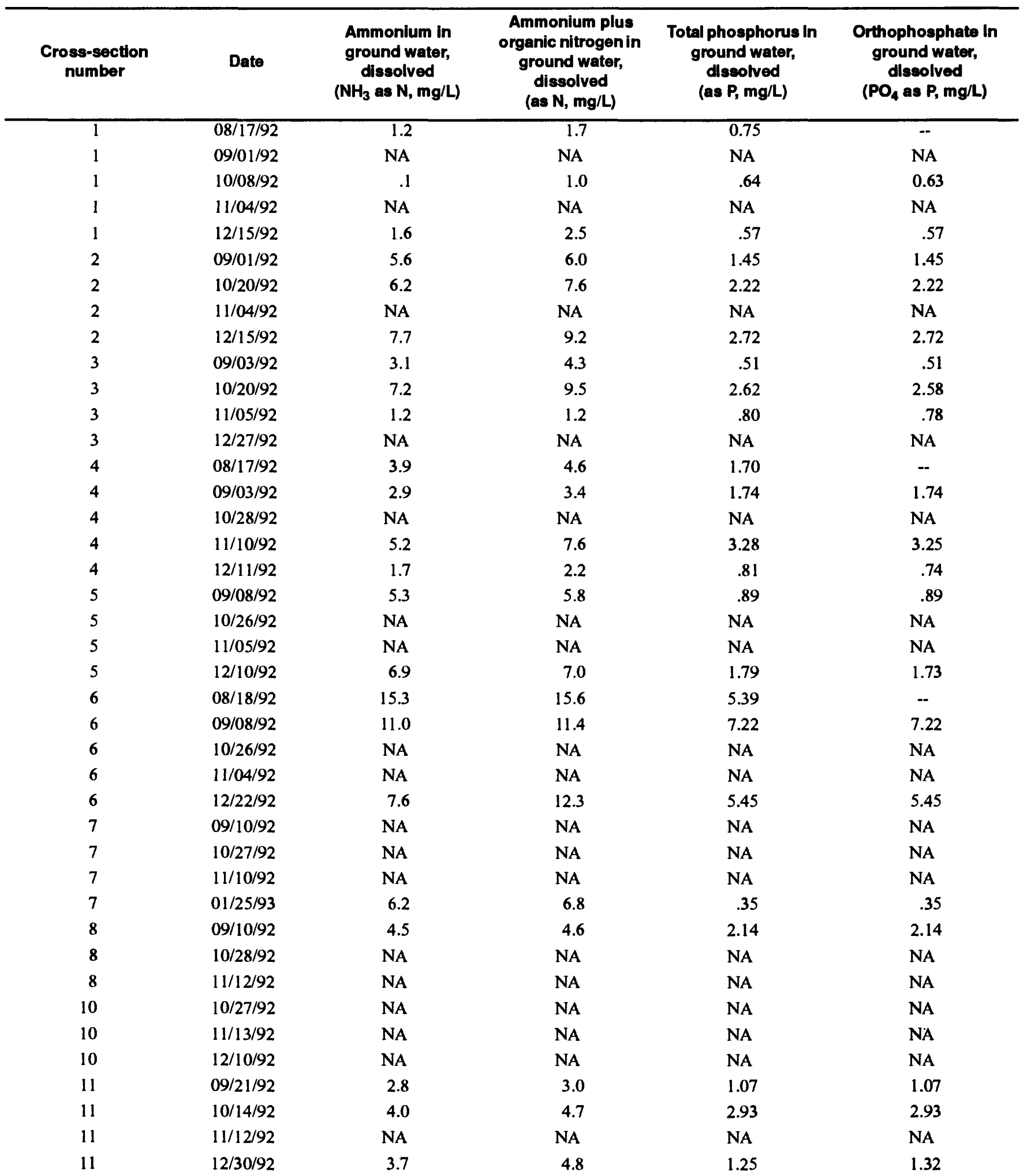


Table 9. Rates of ground-water discharge across the sediment/water interface and quality of surface water and ground water 1 foot below the sediment/water interface at cross-section sites--Continued

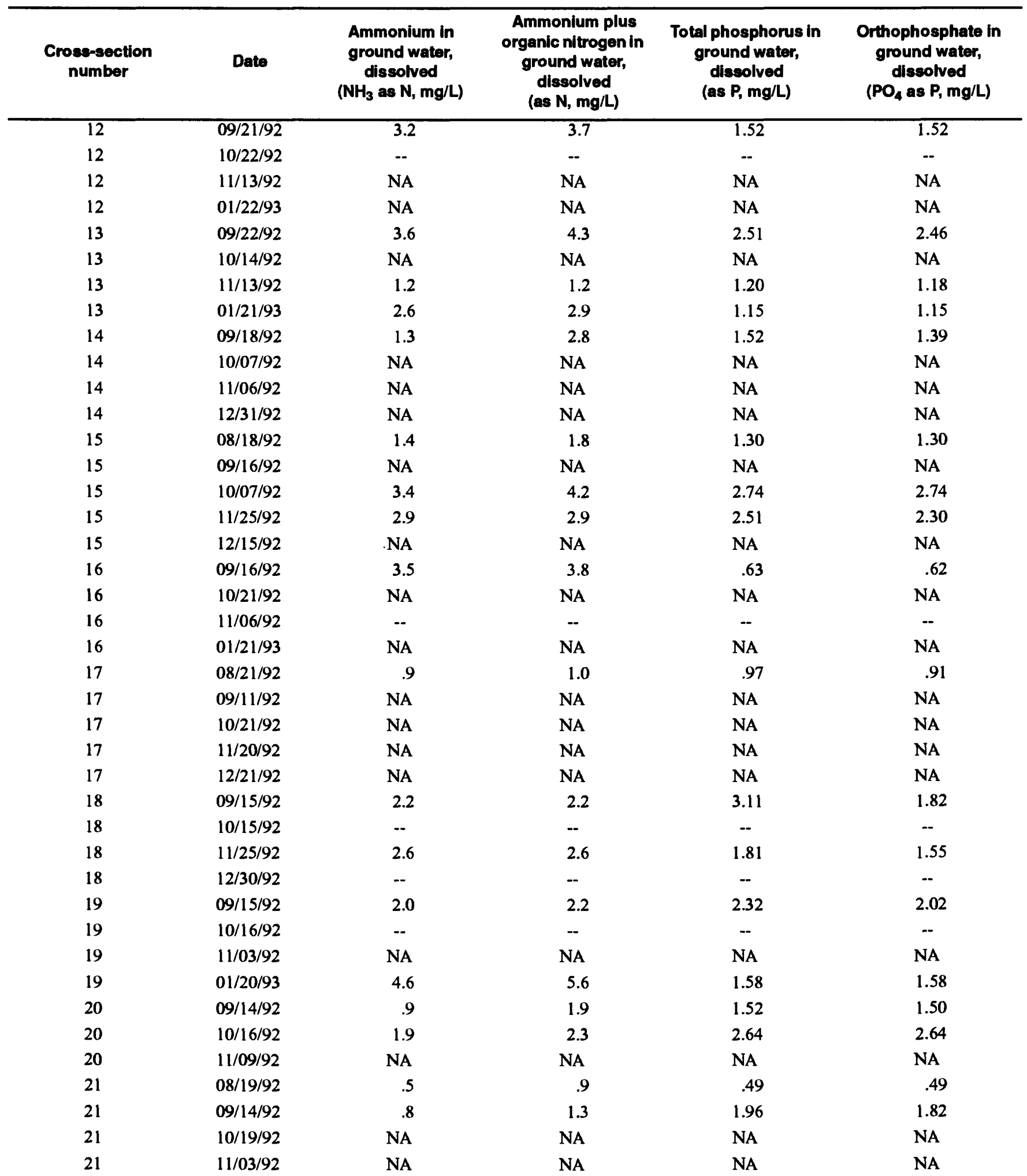


Table 9. Rates of ground-water discharge across the sediment/water interface and quality of surface water and ground water 1 foot below the sediment/water interface at cross-section sites--Continued

\begin{tabular}{|c|c|c|c|c|c|}
\hline $\begin{array}{l}\text { Cross-section } \\
\text { numbsr }\end{array}$ & Date & $\begin{array}{l}\text { Ammonium in } \\
\text { ground water, } \\
\text { dissolved } \\
\left(\mathrm{NH}_{3} \text { as } \mathrm{N}, \mathrm{mg} / \mathrm{L}\right)\end{array}$ & $\begin{array}{l}\text { Ammonium plus } \\
\text { organic nitrogen in } \\
\text { ground water, } \\
\text { dissoived } \\
\text { (as N, mg/L) }\end{array}$ & $\begin{array}{l}\text { Total phosphorus in } \\
\text { ground water, } \\
\text { dissolved } \\
\text { (as } P, \mathrm{mg} / \mathrm{L} \text { ) }\end{array}$ & $\begin{array}{l}\text { Orthophosphate in } \\
\text { ground water, } \\
\text { dissolved } \\
\left(\mathrm{PO}_{4} \text { as } \mathrm{P}, \mathrm{mg} / \mathrm{L}\right)\end{array}$ \\
\hline 21 & $01 / 20 / 93$ & 3.1 & 3.6 & 1.35 & 1.35 \\
\hline 22 & $09 / 09 / 92$ & 1.0 & 4.4 & 1.70 & 1.70 \\
\hline 22 & $10 / 19 / 92$ & 2.1 & 2.3 & .67 & .67 \\
\hline 22 & $11 / 27 / 92$ & 1.4 & 1.9 & 1.02 & .99 \\
\hline 22 & $12 / 09 / 92$ & 3.5 & 3.7 & 2.42 & 2.31 \\
\hline 23 & $09 / 09 / 92$ & .9 & 2.5 & 1.78 & 1.78 \\
\hline 23 & $11 / 17 / 92$ & .7 & 1.5 & 2.24 & 2.13 \\
\hline 23 & $12 / 14 / 92$ & 3.5 & 3.9 & 2.17 & 2.17 \\
\hline 24 & 09/04/92 & .9 & .9 & 1.14 & 1.14 \\
\hline 24 & $10 / 15 / 92$ & 1.3 & 1.7 & 2.13 & 2.13 \\
\hline 24 & $11 / 18 / 92$ & .9 & 1.1 & 1.52 & 1.52 \\
\hline 24 & $12 / 09 / 92$ & 3.8 & 4.3 & 2.08 & 2.08 \\
\hline 25 & $08 / 20 / 92$ & $<.1$ & $<.1$ & 1.37 & 1.23 \\
\hline 25 & $09 / 02 / 92$ & 1.0 & 1.0 & 1.08 & 1.08 \\
\hline 25 & $11 / 18 / 92$ & NA & NA & NA & NA \\
\hline 25 & $12 / 03 / 92$ & NA & NA & NA & NA \\
\hline 26 & $08 / 31 / 92$ & .3 & .7 & .48 & .48 \\
\hline 26 & $09 / 30 / 92$ & 1.0 & 1.2 & .51 & .51 \\
\hline 26 & $10 / 06 / 92$ & $<.1$ & .3 & .74 & .74 \\
\hline 26 & $11 / 19 / 92$ & .3 & .5 & .62 & .62 \\
\hline 26 & $12 / 03 / 92$ & 1.3 & 1.9 & 1.17 & 1.08 \\
\hline 27 & $09 / 22 / 92$ & 1.2 & 1.6 & 2.56 & 2.56 \\
\hline 27 & $10 / 06 / 92$ & NA & NA & NA & NA \\
\hline 27 & $11 / 09 / 92$ & NA & NA & NA & NA \\
\hline 27 & $12 / 14 / 92$ & 3.7 & 4.7 & .96 & .96 \\
\hline 28 & 09/04/92 & 1.1 & 1.1 & .73 & .73 \\
\hline 28 & $10 / 23 / 92$ & NA & NA & NA & NA \\
\hline 28 & $11 / 17 / 92$ & $<.1$ & .6 & 1.79 & 1.70 \\
\hline 28 & $12 / 29 / 92$ & NA & NA & NA & NA \\
\hline 29 & $08 / 21 / 92$ & .3 & .4 & .85 & .85 \\
\hline 29 & $09 / 02 / 92$ & .7 & 1.4 & .64 & .64 \\
\hline 29 & $10 / 13 / 92$ & NA & NA & NA & NA \\
\hline 29 & $11 / 16 / 92$ & $<.1$ & $<.1$ & .60 & .60 \\
\hline 29 & $12 / 29 / 92$ & 1.5 & 2.4 & .28 & .22 \\
\hline 30 & $08 / 20 / 92$ & -- & -- & -- & 1.14 \\
\hline 30 & $09 / 30 / 92$ & .8 & 1.3 & .85 & .83 \\
\hline 30 & $10 / 13 / 92$ & $<.1$ & .9 & 1.15 & 1.15 \\
\hline 30 & $11 / 16 / 92$ & NA & NA & NA & NA \\
\hline 30 & $12 / 21 / 92$ & 1.7 & 2.3 & 1.60 & 1.60 \\
\hline
\end{tabular}


Table 10. Water-quality data for water from the South Platte River, piezometers, and wells at McKay Road, Henderson, and Road 8

[in., inches; ${ }^{\circ} \mathrm{C}$, degree Celsius; $\mu \mathrm{S} / \mathrm{cm}$, microsiemens per centimeter at 25 degrees Celsius; $\mathrm{mg} / \mathrm{L}$, milligram per liter; NA, not applicable; --, missing data; $<$, less than]

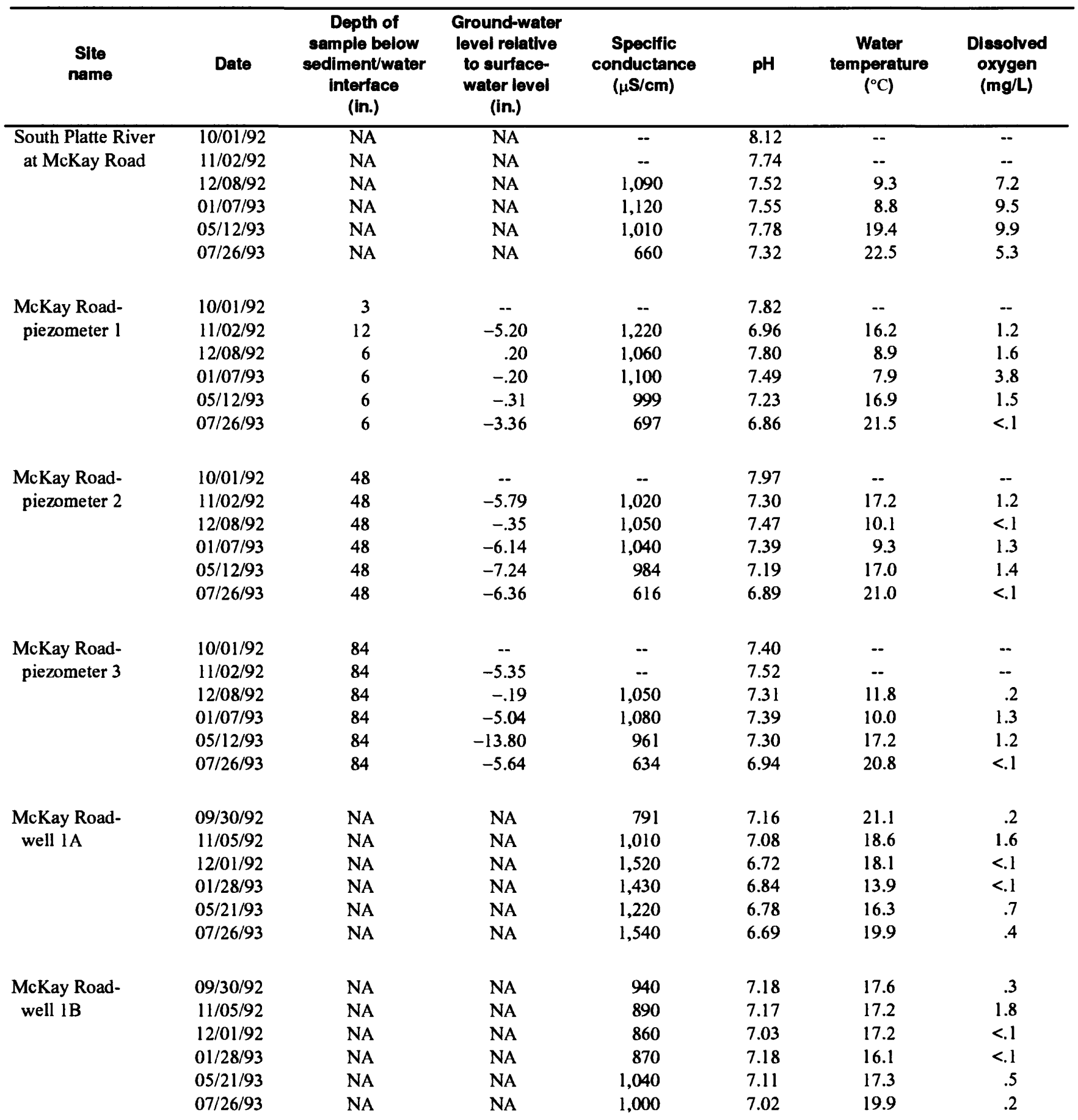


Table 10. Water-quality data for water from the South Platte River, piezometers, and wells at McKay Road, Henderson, and Road 8--Continued

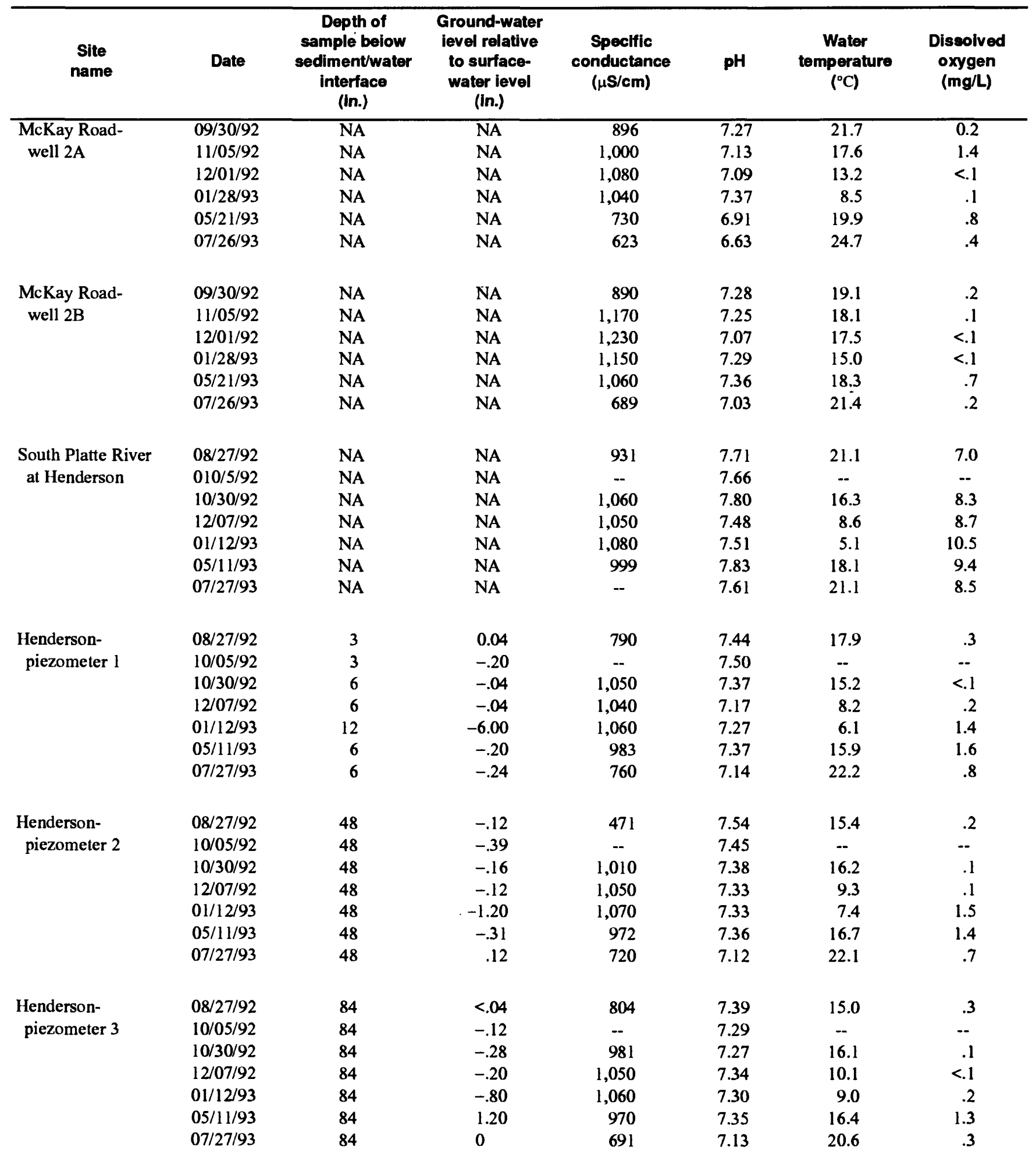


Table 10. Water-quality data for water from the South Platte River, piezometers, and wells at McKay Road, Henderson, and Road 8--Continued

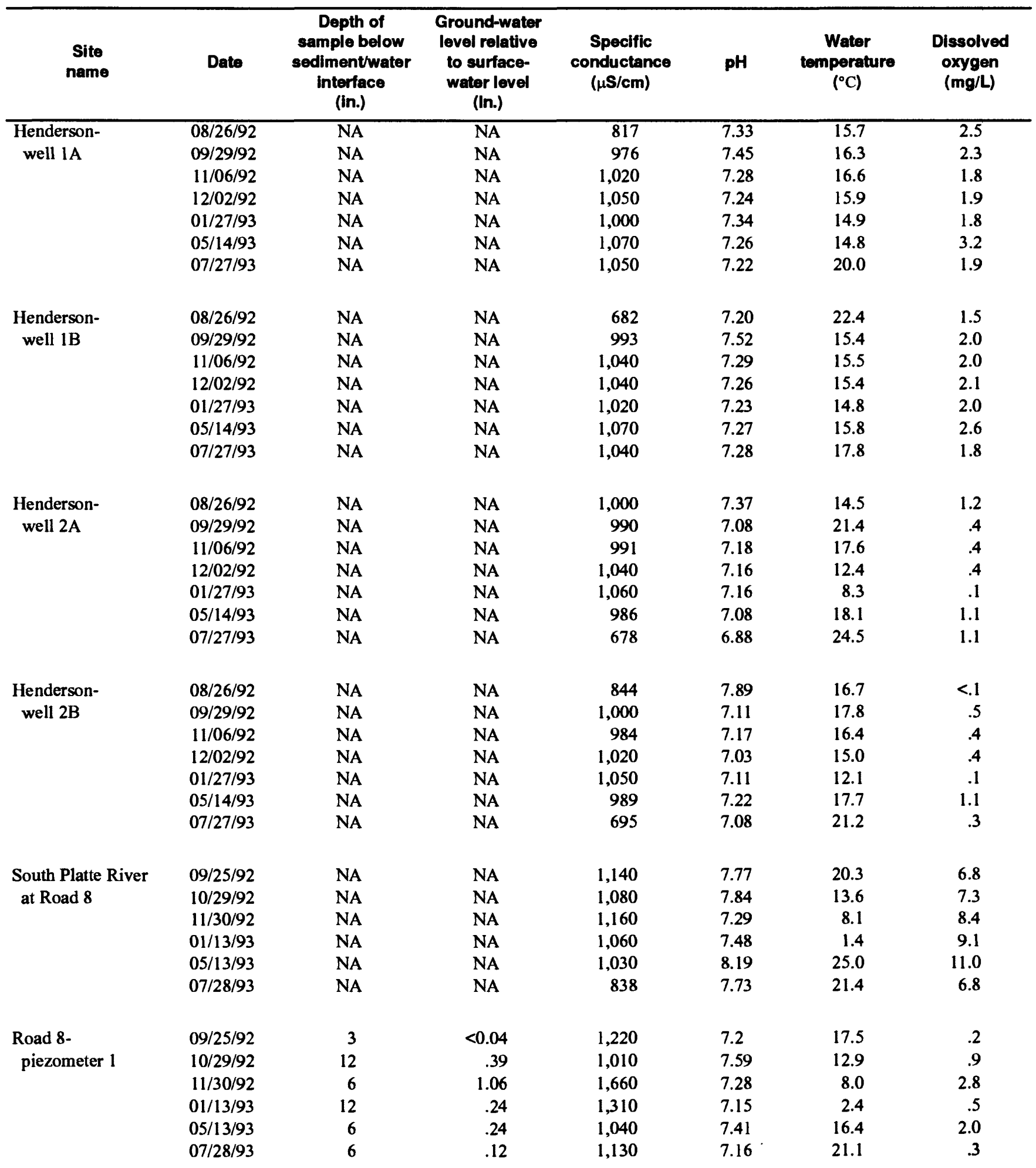


Table 10. Water-quality data for water from the South Platte River, piezometers, and wells at McKay Road, Henderson, and Road 8--Continued

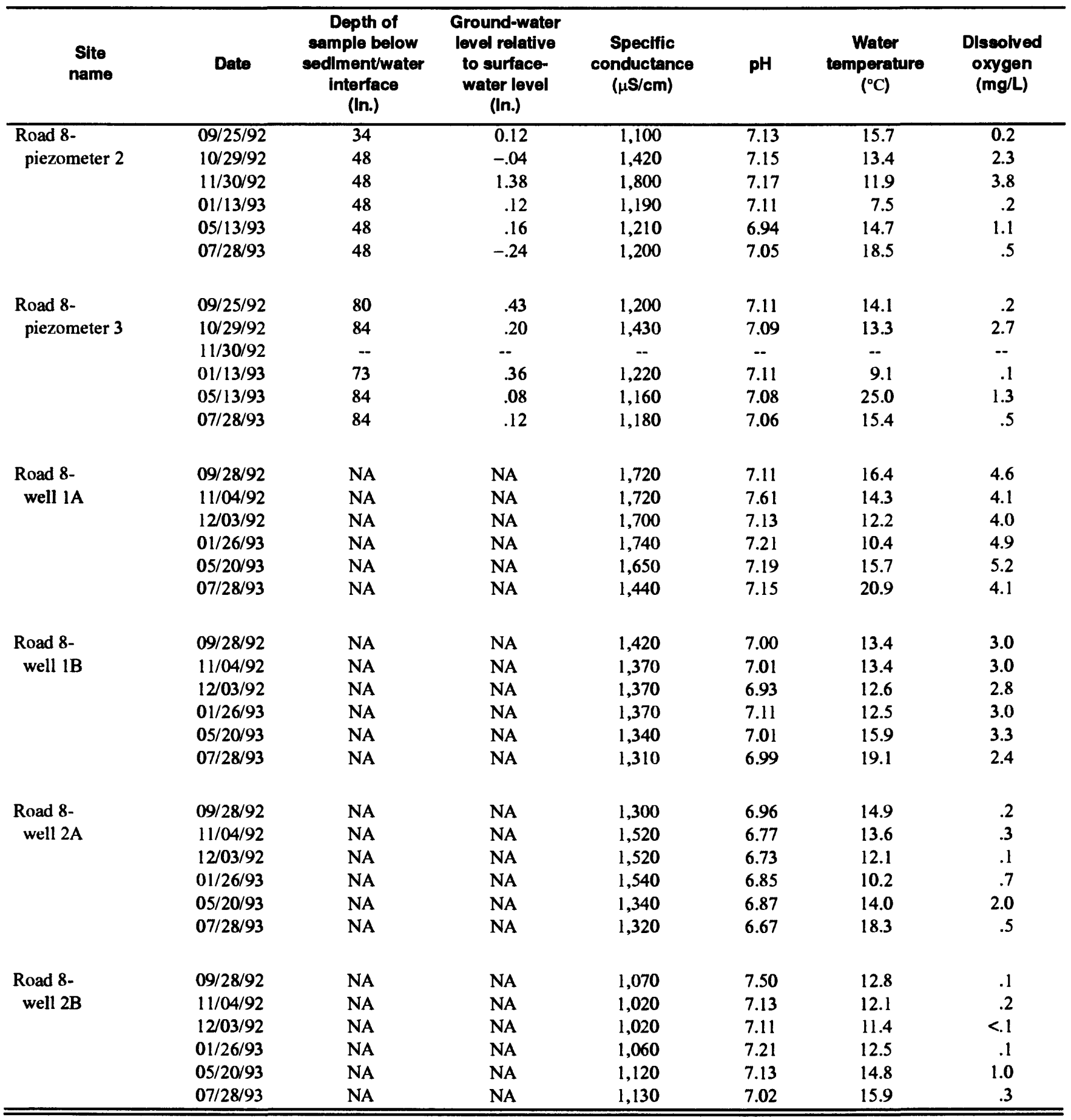


Table 10. Water-quality data for water from the South Platte River, piezometers, and wells at McKay Road, Henderson, and Road 8--Continued

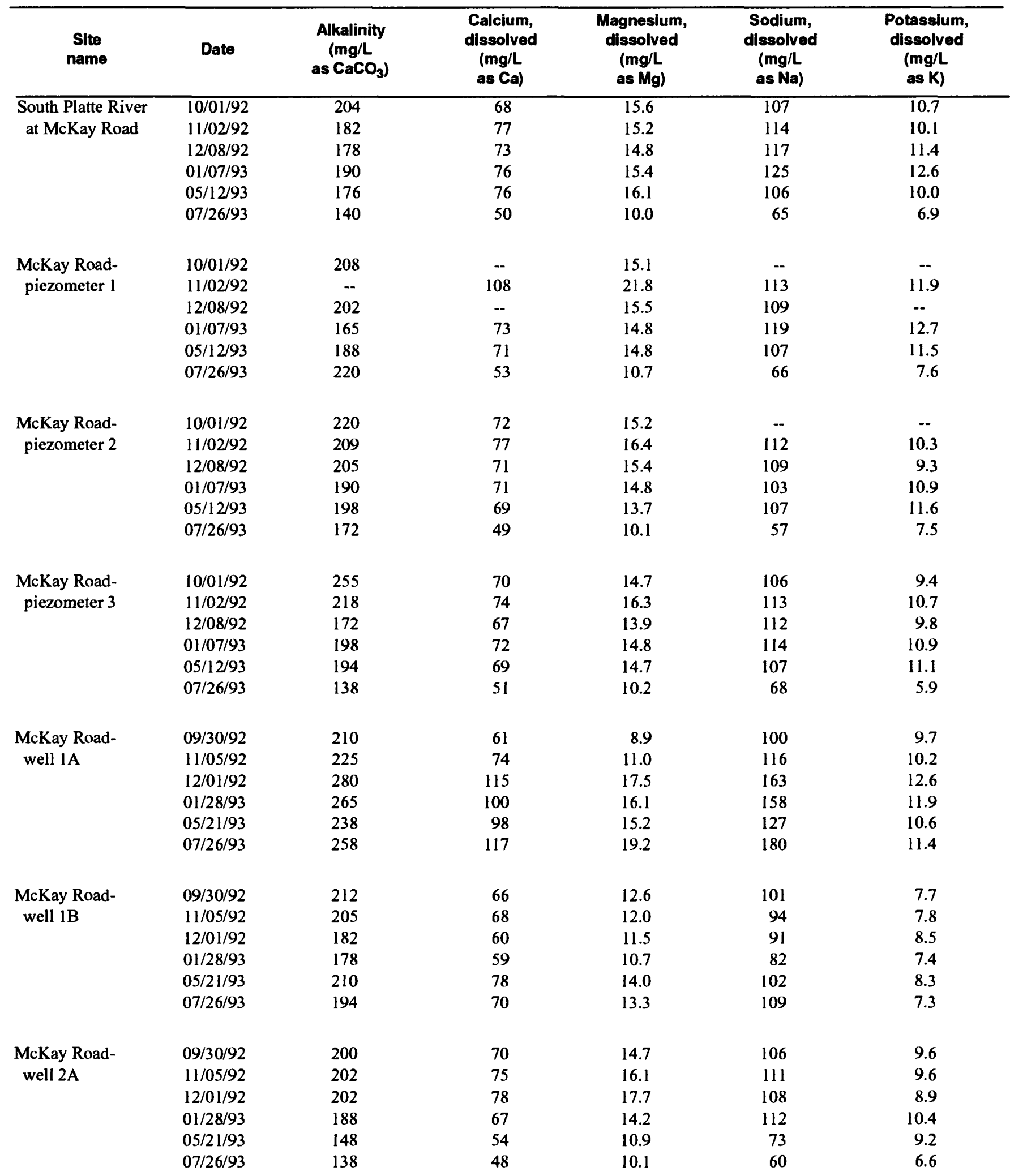


Table 10. Water-quality data for water from the South Platte River, piezometers, and wells at McKay Road, Henderson, and Road 8--Continued

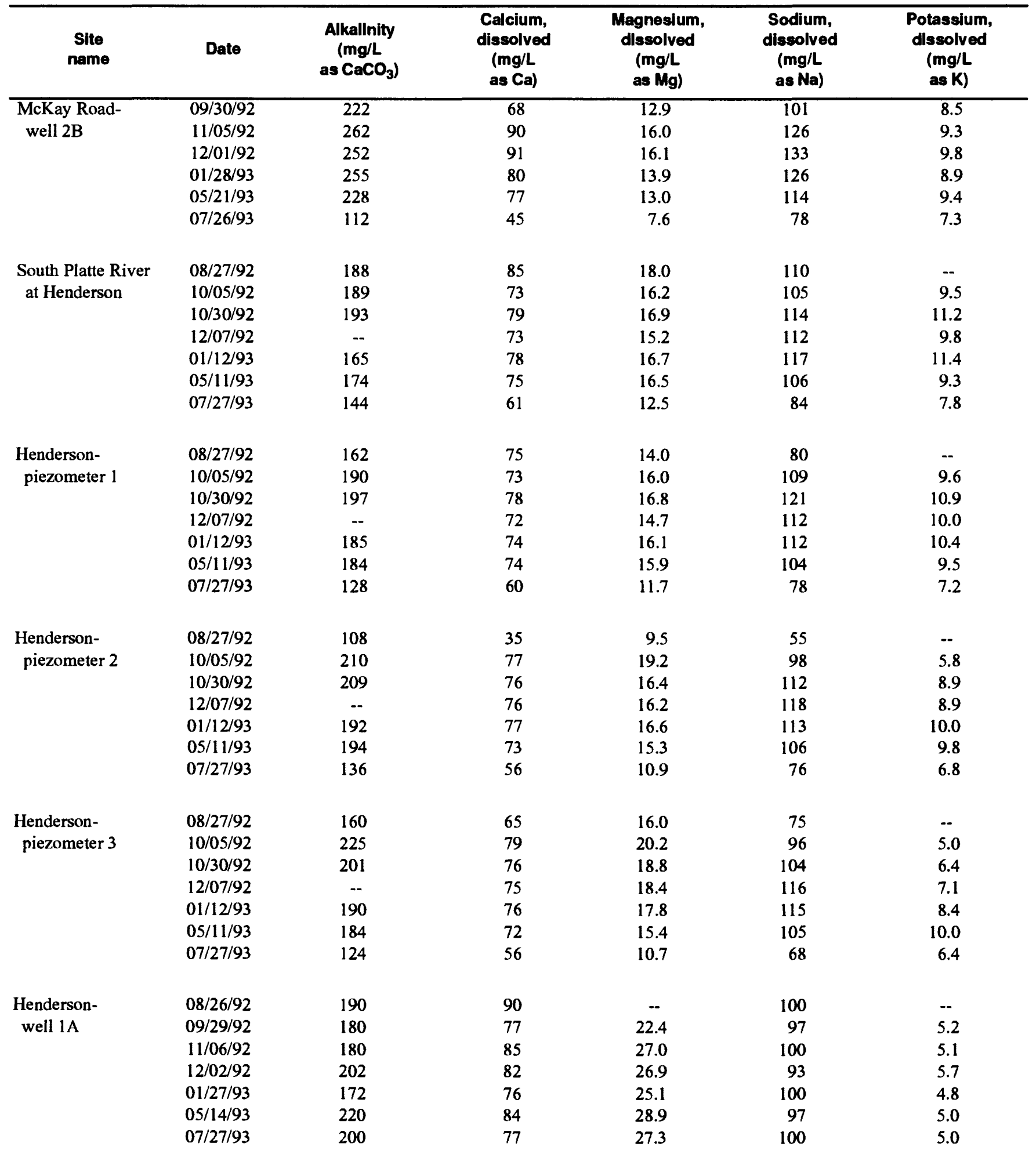


Table 10. Water-quality data for water from the South Platte River, piezometers, and wells at McKay Road, Henderson, and Road 8--Continued

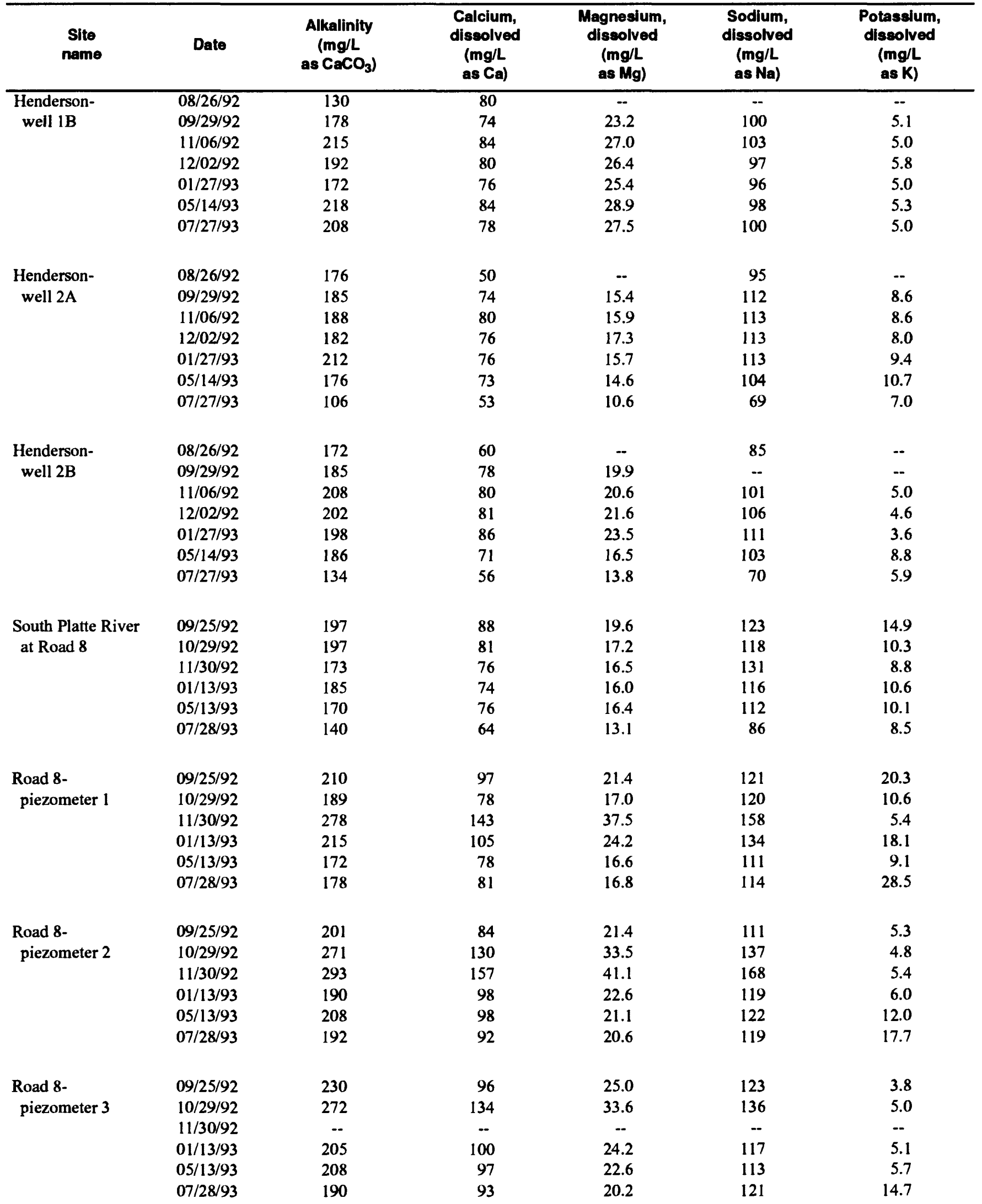


Table 10. Water-quality data for water from the South Platte River, piezometers, and wells at McKay Road, Henderson, and Road 8--Continued

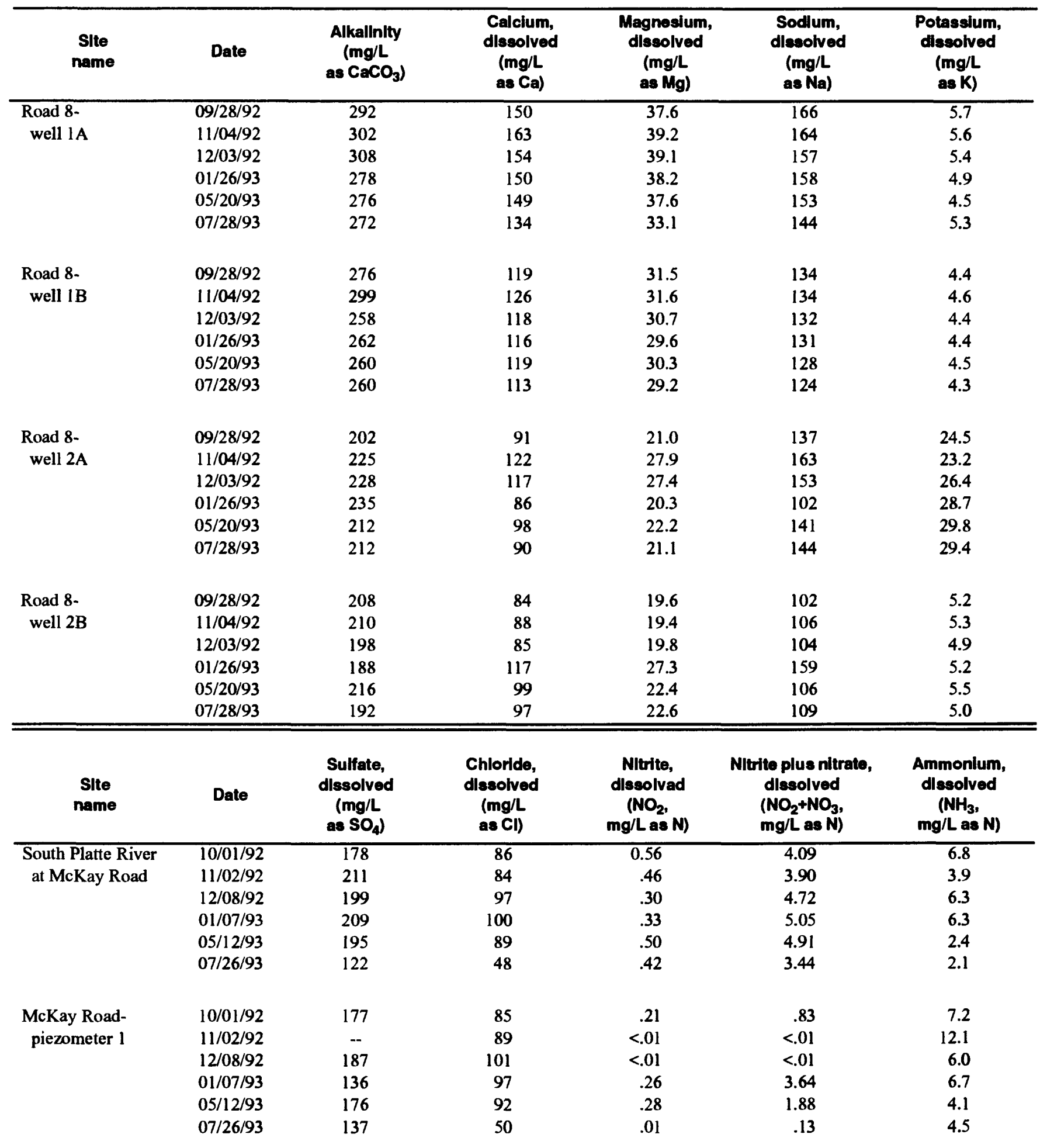


Table 10. Water-quality data for water from the South Platte River, piezometers, and wells at McKay Road, Henderson, and Road 8--Continued

\begin{tabular}{|c|c|c|c|c|c|c|}
\hline $\begin{array}{l}\text { Site } \\
\text { name }\end{array}$ & Date & $\begin{array}{c}\text { Suifate, } \\
\text { dissolved } \\
(\mathrm{mg} / \mathrm{L} \\
\left.\text { as } \mathrm{SO}_{4}\right)\end{array}$ & $\begin{array}{l}\text { Chloride, } \\
\text { dissolved } \\
\text { (mg/L } \\
\text { as Cl) }\end{array}$ & $\begin{array}{c}\text { Nitrite, } \\
\text { dissolved } \\
\left(\mathrm{NO}_{2},\right. \\
\mathrm{mg} / \mathrm{L} \mathrm{as} \mathrm{N})\end{array}$ & $\begin{array}{l}\text { Nitrite plus nitrate, } \\
\text { dlssolved } \\
\left(\mathrm{NO}_{2}+\mathrm{NO}_{3}\right. \\
\mathrm{mg} / \mathrm{L} \text { as } \mathrm{N})\end{array}$ & $\begin{array}{c}\text { Ammonium, } \\
\text { dissolved } \\
\text { ( } \mathrm{NH}_{3}, \\
\mathrm{mg} / \mathrm{L} \text { as } \mathrm{N} \text { ) }\end{array}$ \\
\hline \multirow{4}{*}{$\begin{array}{r}\text { McKay Road- } \\
\text { piezometer } 2\end{array}$} & $11 / 02 / 92$ & 186 & 91 & $<.01$ & $<.01$ & 5.2 \\
\hline & $12 / 08 / 92$ & 184 & 94 & $<.01$ & .12 & 4.8 \\
\hline & $01 / 07 / 93$ & 191 & 88 & $<.01$ & $<.01$ & 5.4 \\
\hline & $07 / 26 / 93$ & 61 & 46 & $<.01$ & $<.01$ & 2.9 \\
\hline \multirow{3}{*}{$\begin{array}{l}\text { McKay Road- } \\
\text { piezometer } 3\end{array}$} & $10 / 01 / 92$ & 154 & 86 & $<.01$ & $<.01$ & 8.0 \\
\hline & $11 / 02 / 92$ & 190 & 92 & $<.01$ & $<.01$ & 4.3 \\
\hline & $12 / 08 / 92$ & 197 & 96 & .25 & -- & 7.4 \\
\hline \multirow{6}{*}{$\begin{array}{l}\text { McKay Road- } \\
\text { well IA }\end{array}$} & $09 / 30 / 92$ & 122 & 74 & $<.01$ & .05 & 7.8 \\
\hline & $11 / 05 / 92$ & 135 & 100 & $<.01$ & .02 & 8.2 \\
\hline & $12 / 01 / 92$ & -- & 165 & $<.01$ & $<.01$ & 9.2 \\
\hline & $01 / 28 / 93$ & 235 & 158 & .02 & .03 & 5.4 \\
\hline & $05 / 21 / 93$ & 197 & 130 & $<.01$ & $<.01$ & 4.6 \\
\hline & $07 / 26 / 93$ & 276 & 190 & $<.01$ & $<.01$ & 2.8 \\
\hline \multirow{4}{*}{$\begin{array}{l}\text { McKay Road- } \\
\text { well lB }\end{array}$} & 09/30/92 & 136 & 82 & $<.01$ & $<.01$ & 5.3 \\
\hline & $11 / 05 / 92$ & 148 & 79 & $<.01$ & $<.01$ & 5.5 \\
\hline & $12 / 01 / 92$ & 192 & 68 & $<.01$ & $<.01$ & 5.3 \\
\hline & $01 / 28 / 93$ & 157 & 75 & .02 & .02 & 4.6 \\
\hline \multirow{2}{*}{$\begin{array}{l}\text { McKay Road- } \\
\text { well 2A }\end{array}$} & $05 / 21 / 93$ & 73 & 58 & $<.01$ & .18 & 2.1 \\
\hline & $07 / 26 / 93$ & 102 & 48 & $<.01$ & .07 & 1.3 \\
\hline \multirow{6}{*}{$\begin{array}{l}\text { McKay Road- } \\
\text { well 2B }\end{array}$} & $09 / 30 / 92$ & 143 & 89 & $<.01$ & $<.01$ & 6.2 \\
\hline & $11 / 05 / 92$ & 197 & 133 & $<.01$ & $<.01$ & 6.9 \\
\hline & $12 / 01 / 92$ & 207 & 128 & $<.01$ & $<.01$ & 6.5 \\
\hline & $01 / 28 / 93$ & 166 & 112 & .02 & .04 & 5.4 \\
\hline & $05 / 21 / 93$ & 170 & 101 & $<.01$ & $<.01$ & 6.2 \\
\hline & $07 / 26 / 93$ & 107 & 54 & $<.01$ & $<.01$ & 3.9 \\
\hline \multirow{7}{*}{$\begin{array}{l}\text { South Platte River } \\
\text { at Henderson }\end{array}$} & $08 / 27 / 92$ & 178 & 70 & .14 & 2.06 & 3.0 \\
\hline & $10 / 05 / 92$ & 193 & 87 & .65 & 5.73 & 7.1 \\
\hline & $10 / 30 / 92$ & 211 & 113 & $<.01$ & 5.04 & 6.1 \\
\hline & $12 / 07 / 92$ & 222 & 91 & .30 & 5.55 & 6.3 \\
\hline & $01 / 12 / 93$ & 206 & 89 & .36 & 5.23 & 6.6 \\
\hline & $05 / 11 / 93$ & 206 & 92 & .71 & 4.49 & 3.1 \\
\hline & $07 / 27 / 93$ & 151 & 66 & .57 & 4.98 & 2.0 \\
\hline
\end{tabular}


Table 10. Water-quality data for water from the South Platte River, piezometers, and wells at McKay Road, Henderson, and Road 8--Continued

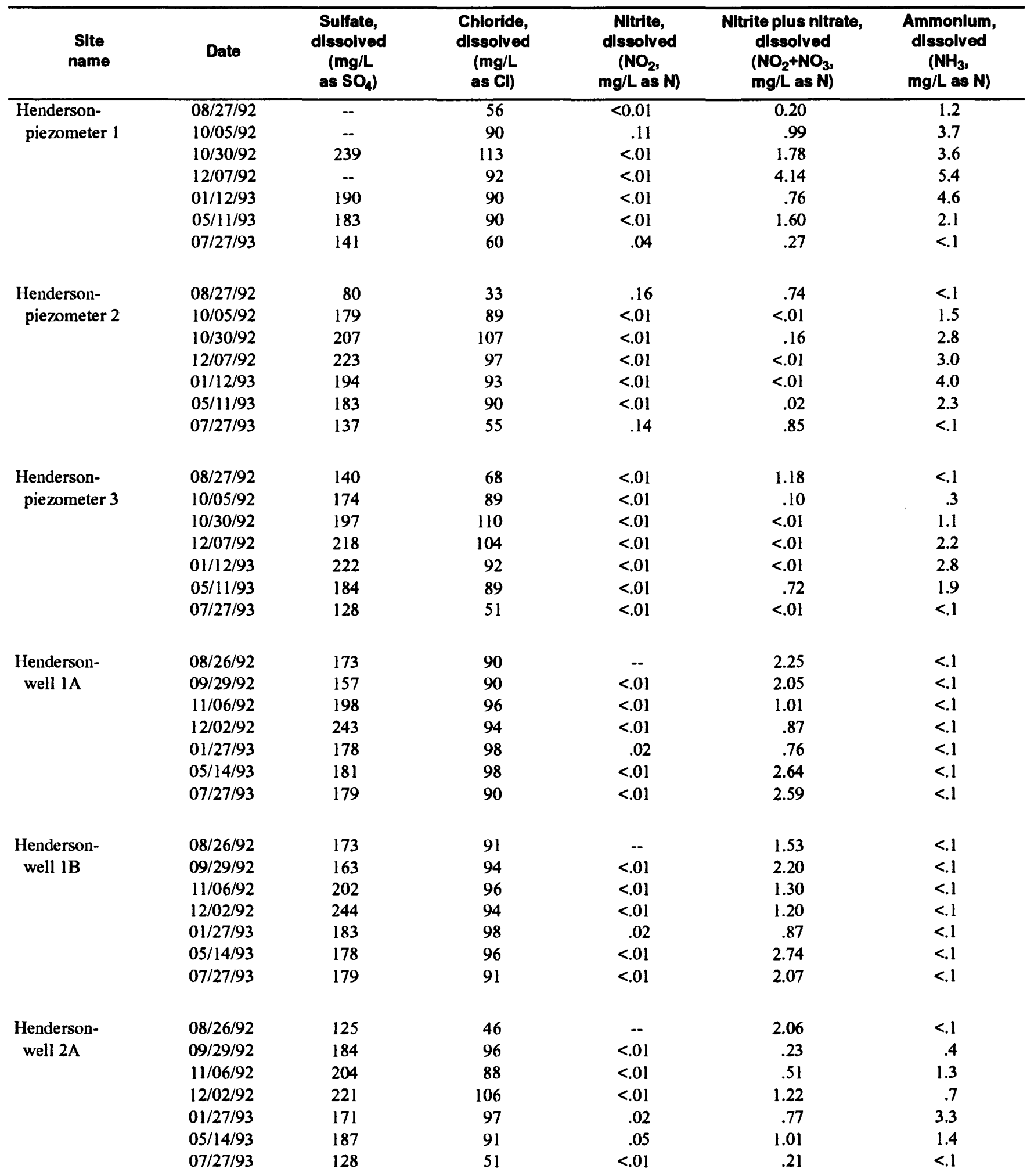


Table 10. Water-quality data for water from the South Platte River, piezometers, and wells at McKay Road, Henderson, and Road 8--Continued

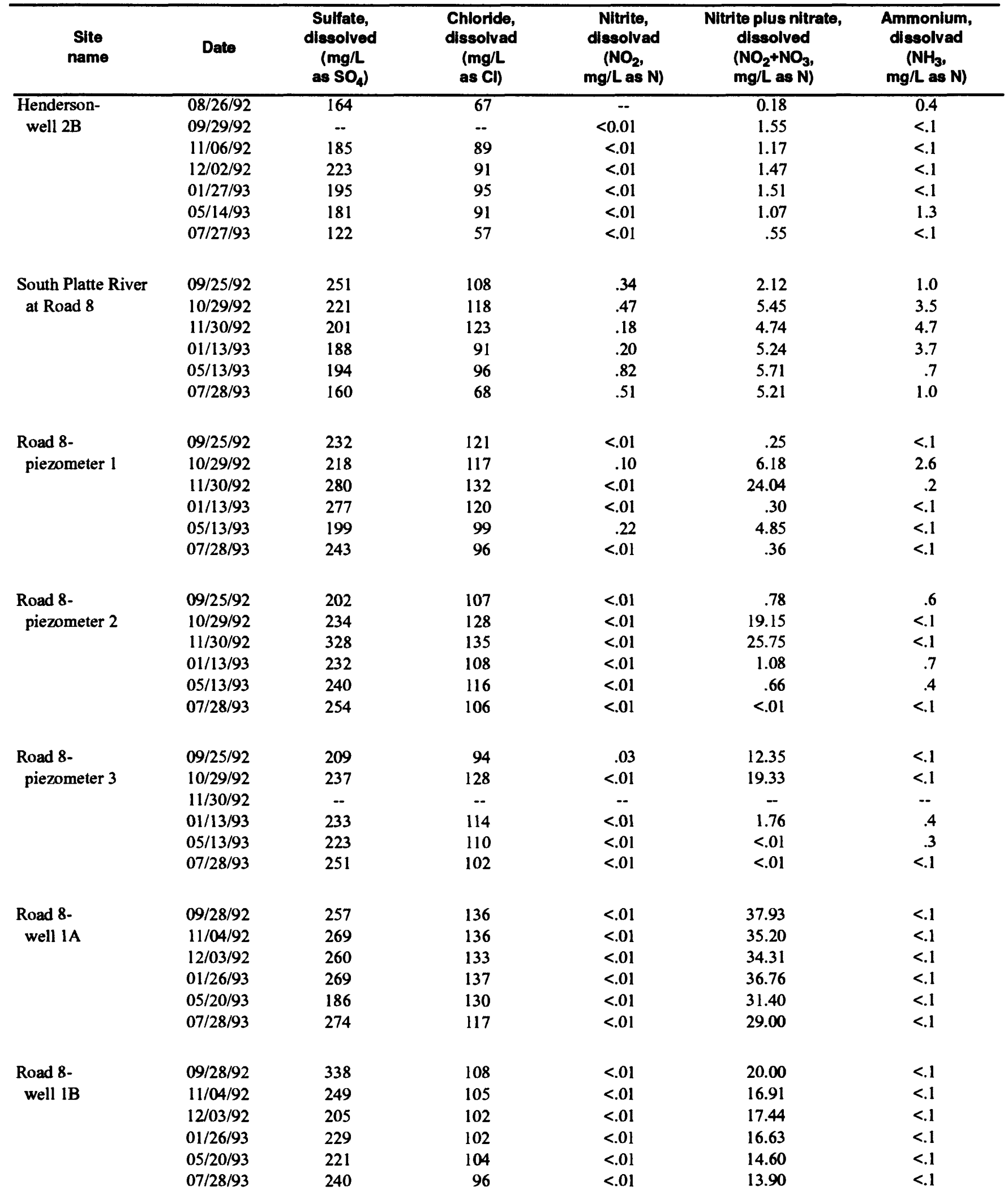


Table 10. Water-quality data for water from the South Platte River, piezometers, and wells at McKay Road, Henderson, and Road 8--Continued

\begin{tabular}{|c|c|c|c|c|c|c|c|}
\hline $\begin{array}{c}\text { Site } \\
\text { name }\end{array}$ & Date & $\begin{array}{l}\text { Sulfate, } \\
\text { dissolved } \\
\text { (mg/L } \\
\left.\text { as } \mathrm{SO}_{4}\right)\end{array}$ & $\begin{array}{l}\text { Chioride, } \\
\text { dlissolved } \\
\text { (mg/L } \\
\text { as Cl) }\end{array}$ & $\begin{array}{c}\text { Nitrite, } \\
\text { dissolved } \\
\text { (NO } \\
\text { mg/L as N) }\end{array}$ & \multicolumn{2}{|c|}{$\begin{array}{c}\text { Nitrite plus nitrate, } \\
\text { disesolved } \\
\left(\mathrm{NO}_{2}+\mathrm{NO}_{3},\right. \\
\mathrm{mg} / \mathrm{L} \text { as } \mathrm{N} \text { ) }\end{array}$} & $\begin{array}{c}\text { Ammonium, } \\
\text { dissolved } \\
\left(\mathrm{NH}_{3},\right. \\
\mathrm{mg} / \mathrm{L} \text { as } \mathrm{N})\end{array}$ \\
\hline \multirow{6}{*}{$\begin{array}{l}\text { Road 8- } \\
\text { well 2A }\end{array}$} & $09 / 28 / 92$ & 254 & 117 & $<0.01$ & \multicolumn{2}{|c|}{0.48} & $<0.1$ \\
\hline & $11 / 04 / 92$ & 376 & 153 & $<.01$ & \multicolumn{2}{|c|}{.58} & $<.1$ \\
\hline & $12 / 03 / 92$ & 320 & 146 & .03 & \multicolumn{2}{|c|}{1.29} & $<.1$ \\
\hline & $01 / 26 / 93$ & 202 & 145 & $<.01$ & \multicolumn{2}{|c|}{.02} & .8 \\
\hline & $05 / 20 / 93$ & 184 & 120 & $<.01$ & \multicolumn{2}{|c|}{1.88} & $<.1$ \\
\hline & $07 / 28 / 93$ & 274 & 115 & $<.01$ & \multicolumn{2}{|c|}{.47} & $<.1$ \\
\hline \multirow{6}{*}{$\begin{array}{l}\text { Road 8- } \\
\text { well 2B }\end{array}$} & $09 / 28 / 92$ & 193 & 90 & $<.01$ & \multicolumn{2}{|c|}{.11} & 1.1 \\
\hline & $11 / 04 / 92$ & 211 & 87 & $<.01$ & \multicolumn{2}{|c|}{$<.01$} & 1.2 \\
\hline & $12 / 03 / 92$ & 200 & 86 & .05 & \multicolumn{2}{|c|}{.10} & 1.2 \\
\hline & $01 / 26 / 93$ & 236 & 89 & $<.01$ & \multicolumn{2}{|c|}{3.25} & $<.1$ \\
\hline & $05 / 20 / 93$ & 221 & 93 & $<.01$ & \multicolumn{2}{|c|}{$<.01$} & 1.2 \\
\hline & $07 / 28 / 93$ & 234 & 90 & $<.01$ & \multicolumn{2}{|c|}{$<.01$} & .9 \\
\hline $\begin{array}{l}\text { Site } \\
\text { name }\end{array}$ & Date & $\begin{array}{c}\text { Ammonium } \\
\text { plus } \\
\text { organic } \\
\text { nitrogen, } \\
\text { dlesolved } \\
\text { (mg/L } \\
\text { as N) }\end{array}$ & $\begin{array}{c}\text { Total } \\
\text { phosphorus, } \\
\text { dliseolved } \\
\text { (mg/L } \\
\text { as P) }\end{array}$ & $\begin{array}{l}\text { Ortho- } \\
\text { phosphate, } \\
\text { dissolved } \\
\text { (PO } \\
\text { mg/L } \\
\text { as P) }\end{array}$ & $\begin{array}{l}\text { Iron, } \\
\text { dissolved } \\
\text { (mg/L } \\
\text { as } F e)\end{array}$ & $\begin{array}{l}\text { Manganese, } \\
\text { dissolved } \\
(\mathbf{m g} / \mathrm{L} \\
\text { as Mn) }\end{array}$ & $\begin{array}{c}\text { Organic } \\
\text { carbon, } \\
\text { total } \\
\text { (mg/L } \\
\text { as C) }\end{array}$ \\
\hline \multirow{6}{*}{$\begin{array}{l}\text { South Platte River } \\
\text { at McKay Road }\end{array}$} & $10 / 01 / 92$ & 7.4 & -- & 3.18 & 0.06 & 0.22 & 10.0 \\
\hline & $11 / 02 / 92$ & 5.8 & 3.15 & 3.15 & .06 & .18 & NA \\
\hline & $12 / 08 / 92$ & 7.5 & 2.96 & 2.83 & .08 & .25 & NA \\
\hline & $01 / 07 / 93$ & 7.5 & 2.79 & 2.62 & .06 & .26 & NA \\
\hline & $05 / 12 / 93$ & 4.5 & 2.39 & 2.30 & .01 & .14 & NA \\
\hline & $07 / 26 / 93$ & 3.1 & 1.07 & 1.05 & .01 & .12 & NA \\
\hline \multirow{6}{*}{$\begin{array}{l}\text { McKay Road- } \\
\text { piezometer } 1\end{array}$} & $10 / 01 / 92$ & 7.6 & -- & 3.67 & .07 & .46 & 8.2 \\
\hline & $11 / 02 / 92$ & 16.4 & 10.38 & 10.38 & .07 & 3.30 & NA \\
\hline & $12 / 08 / 92$ & 6.1 & 4.29 & 4.17 & .28 & .45 & $\mathbf{N A}$ \\
\hline & $01 / 07 / 93$ & 8.0 & 1.75 & 1.66 & .10 & .44 & NA \\
\hline & $05 / 12 / 93$ & 7.1 & 1.98 & 1.98 & .41 & .53 & NA \\
\hline & $07 / 26 / 93$ & 6.8 & 6.45 & 6.06 & .78 & 4.20 & NA \\
\hline \multirow{6}{*}{$\begin{array}{r}\text { McKay Road- } \\
\text { piezometer } 2\end{array}$} & $10 / 01 / 92$ & -- & -- & -- & .11 & .73 & 6.4 \\
\hline & $11 / 02 / 92$ & 6.2 & 3.53 & 3.00 & .08 & .77 & NA \\
\hline & $12 / 08 / 92$ & 5.0 & 4.29 & 2.86 & .15 & .63 & NA \\
\hline & $01 / 07 / 93$ & 5.8 & 1.29 & 1.19 & .19 & .51 & NA \\
\hline & $05 / 12 / 93$ & 7.8 & 3.65 & 3.65 & .10 & 1.04 & NA \\
\hline & $07 / 26 / 93$ & 4.5 & 2.95 & 2.95 & .14 & 1.01 & NA \\
\hline \multirow{6}{*}{$\begin{array}{l}\text { McKay Road- } \\
\text { piezometer } 3\end{array}$} & $10 / 01 / 92$ & 8.3 & -- & 5.24 & .07 & 1.35 & 6.7 \\
\hline & $11 / 02 / 92$ & 5.3 & 3.15 & 3.04 & .34 & .36 & NA \\
\hline & $12 / 08 / 92$ & 7.7 & 3.05 & .91 & .06 & 1.03 & NA \\
\hline & $01 / 07 / 93$ & 6.2 & 1.86 & 1.77 & .36 & .60 & NA \\
\hline & $05 / 12 / 93$ & 3.9 & 1.23 & 1.23 & 1.10 & .29 & NA \\
\hline & $07 / 26 / 93$ & 1.0 & 1.23 & 1.20 & .95 & .41 & NA \\
\hline
\end{tabular}


Table 10. Water-quality data for water from the South Platte River, piezometers, and wells at McKay Road, Henderson, and Road 8--Continued

\begin{tabular}{|c|c|c|c|c|c|c|c|}
\hline $\begin{array}{c}\text { Site } \\
\text { name }\end{array}$ & Date & $\begin{array}{l}\text { Ammonium } \\
\text { pius } \\
\text { organlc } \\
\text { nltrogen, } \\
\text { dlssoived } \\
\text { (mg/L } \\
\text { as N) }\end{array}$ & $\begin{array}{c}\text { Total } \\
\text { phosphorus, } \\
\text { dissolved } \\
\text { (mg/L } \\
\text { as P) }\end{array}$ & $\begin{array}{c}\text { Ortho- } \\
\text { phosphate, } \\
\text { dissolved } \\
\left(\mathrm{PO}_{4},\right. \\
\mathrm{mg} / \mathrm{L} \\
\text { as P) }\end{array}$ & $\begin{array}{c}\text { Iron, } \\
\text { dissolved } \\
\text { (mg/L } \\
\text { as Fe) }\end{array}$ & $\begin{array}{c}\text { Manganese, } \\
\text { dissolved } \\
\text { (mg/L } \\
\text { as Mn) }\end{array}$ & $\begin{array}{c}\text { Organlc } \\
\text { carbon, } \\
\text { total } \\
\text { (mg/L } \\
\text { as C) }\end{array}$ \\
\hline \multirow{6}{*}{$\begin{array}{l}\text { McKay Road- } \\
\text { well lA }\end{array}$} & $09 / 30 / 92$ & 8.8 & 7.24 & 6.97 & 0.28 & 0.66 & 5.9 \\
\hline & $11 / 05 / 92$ & 7.3 & 5.34 & 5.34 & .37 & .83 & NA \\
\hline & $12 / 01 / 92$ & 8.6 & 3.22 & 3.22 & .59 & 1.46 & NA \\
\hline & $01 / 28 / 93$ & 6.1 & 1.62 & 1.62 & .44 & 1.50 & NA \\
\hline & $05 / 21 / 93$ & 5.1 & 1.84 & 1.77 & .43 & 1.43 & NA \\
\hline & $07 / 26 / 93$ & 4.8 & 1.41 & 1.41 & .55 & 1.90 & NA \\
\hline \multirow{6}{*}{$\begin{array}{l}\text { McKay Road- } \\
\text { well IB }\end{array}$} & $09 / 30 / 92$ & 6.1 & .97 & .97 & $<.01$ & 3.40 & 4.2 \\
\hline & $11 / 05 / 92$ & 7.4 & .99 & .99 & $<.01$ & 3.30 & NA \\
\hline & $12 / 01 / 92$ & 5.2 & .96 & .95 & $<.01$ & 2.96 & NA \\
\hline & $01 / 28 / 93$ & 6.3 & .63 & .63 & $<.01$ & 3.50 & NA \\
\hline & $05 / 21 / 93$ & 5.3 & .80 & .73 & .01 & 4.00 & NA \\
\hline & $07 / 26 / 93$ & 5.0 & .55 & .55 & .01 & 4.10 & NA \\
\hline \multirow{6}{*}{$\begin{array}{l}\text { McKay Road- } \\
\text { well 2A }\end{array}$} & $09 / 30 / 92$ & 5.6 & 2.55 & 2.52 & .43 & .60 & 5.8 \\
\hline & $11 / 05 / 92$ & -- & -- & 2.70 & .31 & .63 & NA \\
\hline & $12 / 01 / 92$ & 4.1 & 2.29 & 2.29 & .49 & .66 & NA \\
\hline & $01 / 28 / 93$ & 6.5 & 1.42 & 1.42 & .41 & .58 & NA \\
\hline & $05 / 21 / 93$ & 3.2 & 2.26 & 2.26 & .37 & .36 & NA \\
\hline & $07 / 26 / 93$ & 2.0 & 1.70 & 1.70 & .62 & .37 & NA \\
\hline \multirow{6}{*}{$\begin{array}{l}\text { McKay Road- } \\
\text { well 2B }\end{array}$} & $09 / 30 / 92$ & 6.2 & 2.80 & 2.64 & 1.92 & 2.00 & 4.4 \\
\hline & $11 / 05 / 92$ & 9.2 & 2.66 & 1.97 & 2.44 & 2.50 & NA \\
\hline & $12 / 01 / 92$ & 6.4 & 2.51 & 2.27 & 2.78 & 2.36 & NA \\
\hline & $01 / 28 / 93$ & 5.4 & 2.27 & 2.27 & 2.80 & 2.00 & NA \\
\hline & $05 / 21 / 93$ & 7.7 & 3.11 & 3.11 & 3.14 & 1.24 & NA \\
\hline & $07 / 26 / 93$ & 4.7 & 3.29 & 3.06 & 1.47 & 1.10 & NA \\
\hline \multirow{7}{*}{$\begin{array}{l}\text { South Platte River } \\
\text { at Henderson }\end{array}$} & $08 / 27 / 92$ & 3.5 & 1.55 & 1.48 & $<.01$ & .28 & 6.5 \\
\hline & $10 / 05 / 92$ & 8.0 & 3.00 & 3.00 & $<.01$ & .20 & 9.5 \\
\hline & $10 / 30 / 92$ & 6.5 & 3.02 & 3.02 & $<.01$ & .26 & NA \\
\hline & $12 / 07 / 92$ & 7.7 & 3.01 & 2.86 & .05 & .26 & NA \\
\hline & $01 / 12 / 93$ & 8.0 & 3.13 & 2.66 & .08 & .23 & NA \\
\hline & $05 / 11 / 93$ & 5.2 & 2.06 & 1.96 & .01 & .18 & NA \\
\hline & $07 / 27 / 93$ & 3.8 & 1.48 & 1.44 & .01 & .18 & NA \\
\hline \multirow{7}{*}{$\begin{array}{l}\text { Henderson- } \\
\text { piezometer } 1\end{array}$} & $08 / 27 / 92$ & 1.3 & .42 & .38 & $<.01$ & .91 & 5.5 \\
\hline & $10 / 05 / 92$ & 5.2 & 2.19 & 2.13 & $<.01$ & .46 & 6.9 \\
\hline & $10 / 30 / 92$ & 3.9 & 2.97 & 2.97 & $<.01$ & .42 & NA \\
\hline & $12 / 07 / 92$ & 6.3 & 2.56 & 2.49 & $<.01$ & .33 & NA \\
\hline & $01 / 12 / 93$ & 5.0 & 2.60 & 2.46 & $<.01$ & .45 & NA \\
\hline & $05 / 11 / 93$ & 3.7 & 2.40 & 2.40 & .01 & .31 & NA \\
\hline & $07 / 27 / 93$ & 1.2 & 1.17 & 1.17 & .01 & .50 & NA \\
\hline
\end{tabular}


Table 10. Water-quality data for water from the South Platte River, piezometers, and wells at McKay Road, Henderson, and Road 8--Continued

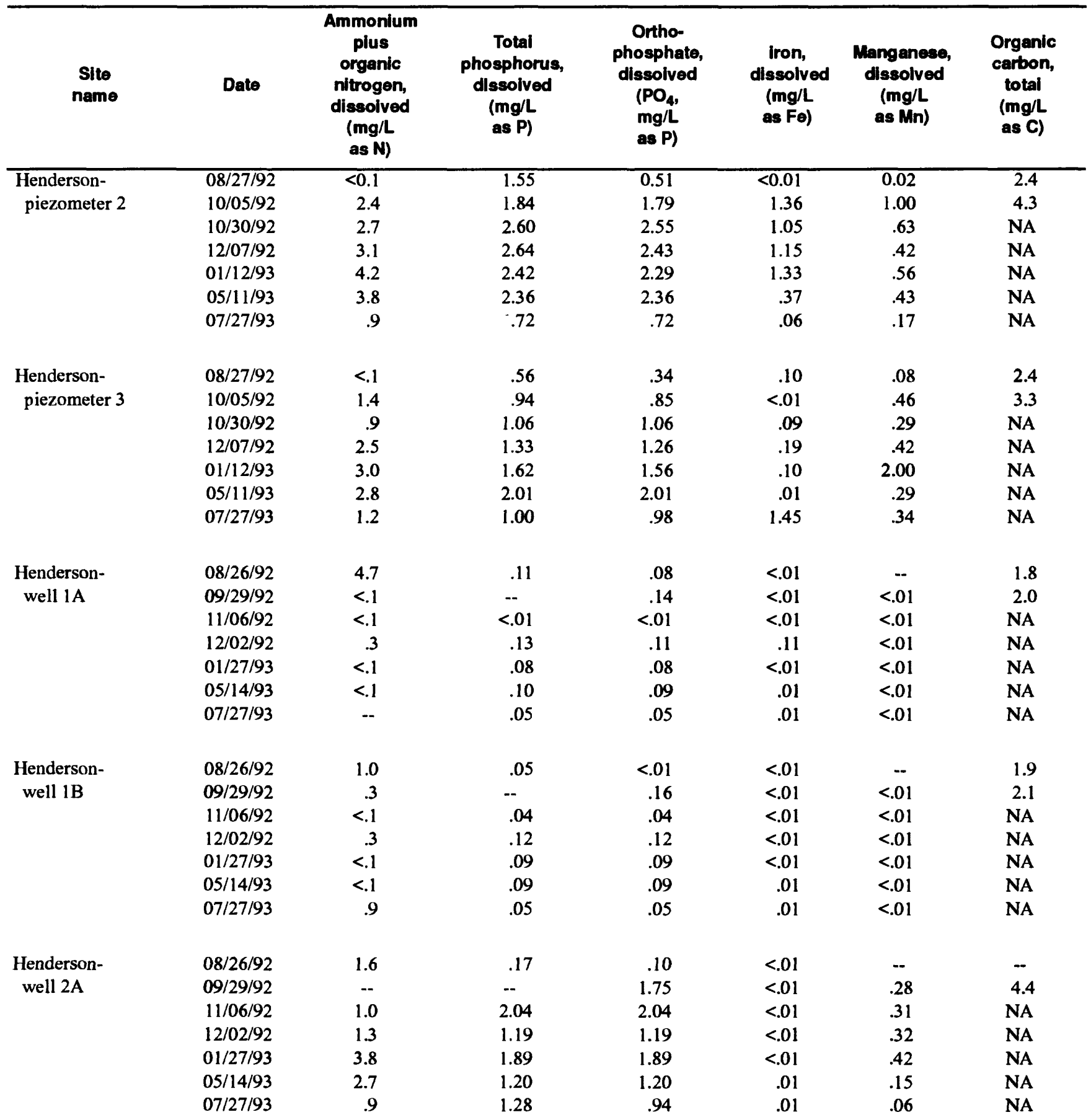


Table 10. Water-quality data for water from the South Platte River, piezometers, and wells at McKay Road, Henderson, and Road 8--Continued

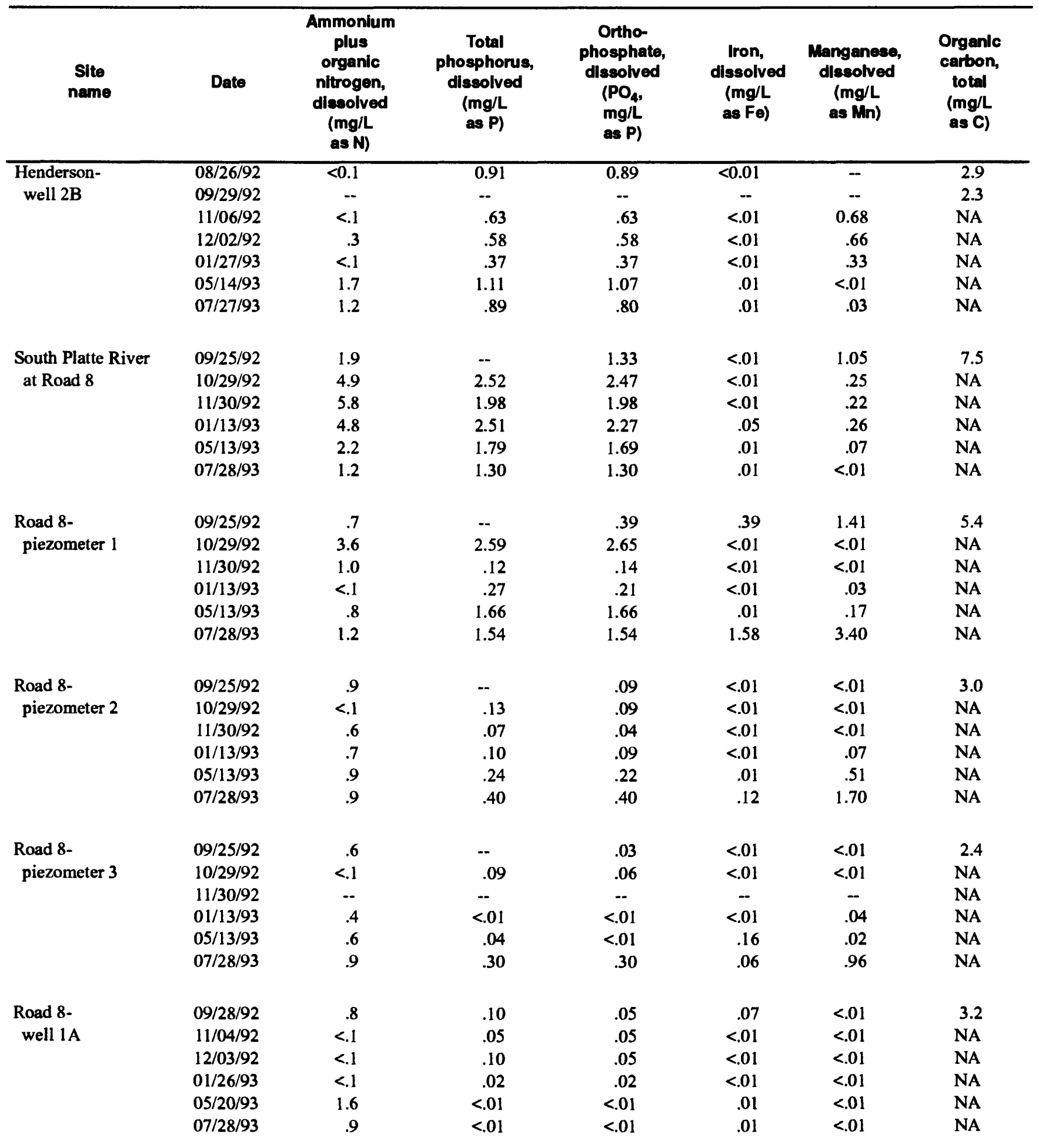


Table 10. Water-quality data for water from the South Platte River, piezometers, and wells at McKay Road, Henderson, and Road 8--Continued

\begin{tabular}{|c|c|c|c|c|c|c|c|}
\hline $\begin{array}{c}\text { Slte } \\
\text { name }\end{array}$ & Date & $\begin{array}{l}\text { Ammonium } \\
\text { plus } \\
\text { organic } \\
\text { nitrogen, } \\
\text { dissolved } \\
\text { (mg/L } \\
\text { as N) }\end{array}$ & $\begin{array}{c}\text { Total } \\
\text { Phosphorus, } \\
\text { dissolved } \\
\text { (mg/L } \\
\text { as P) }\end{array}$ & $\begin{array}{l}\text { Ortho- } \\
\text { phosphate, } \\
\text { dissolved } \\
\left(\mathrm{PO}_{4},\right. \\
\text { mg/L } \\
\text { as P) }\end{array}$ & $\begin{array}{c}\text { Iron, } \\
\text { dissolved } \\
\text { (mg/L } \\
\text { as Fe) }\end{array}$ & $\begin{array}{c}\text { Manganese, } \\
\text { dlssolved } \\
\text { (mg/L } \\
\text { as Mn) }\end{array}$ & $\begin{array}{c}\text { Organic } \\
\text { carbon, } \\
\text { total } \\
\text { (mg/L } \\
\text { as C) }\end{array}$ \\
\hline \multirow{6}{*}{$\begin{array}{l}\text { Road 8- } \\
\text { well 1B }\end{array}$} & $09 / 28 / 92$ & $<0.1$ & 0.07 & 0.04 & $<0.01$ & 0.02 & 2.3 \\
\hline & $11 / 04 / 92$ & $<.1$ & .07 & .07 & $<.01$ & $<.01$ & NA \\
\hline & $12 / 03 / 92$ & $<.1$ & .07 & .04 & $<.01$ & $<.01$ & NA \\
\hline & $01 / 26 / 93$ & $<.1$ & $<.01$ & $<.01$ & $<.01$ & $<.01$ & NA \\
\hline & $05 / 20 / 93$ & $<.1$ & .02 & .02 & .01 & $<.01$ & NA \\
\hline & $07 / 28 / 93$ & .9 & $<.01$ & $<.01$ & .01 & $<.01$ & NA \\
\hline \multirow{6}{*}{$\begin{array}{l}\text { Road 8- } \\
\text { well 2A }\end{array}$} & 09/28/92 & .4 & .38 & .38 & .07 & $<.01$ & 3.8 \\
\hline & $11 / 04 / 92$ & $<.1$ & .49 & .49 & $<.01$ & $<.01$ & NA \\
\hline & $12 / 03 / 92$ & $<.1$ & .45 & .45 & $<.01$ & $<.01$ & NA \\
\hline & $01 / 26 / 93$ & .8 & .42 & .42 & $<.01$ & .05 & NA \\
\hline & $05 / 20 / 93$ & .7 & .45 & .44 & .01 & $<.01$ & NA \\
\hline & $07 / 28 / 93$ & .5 & .41 & .41 & .01 & $<.01$ & NA \\
\hline \multirow{6}{*}{$\begin{array}{l}\text { Road 8- } \\
\text { well 2B }\end{array}$} & $09 / 28 / 92$ & 1.3 & $<.01$ & $<.01$ & $<.01$ & .17 & 2.6 \\
\hline & $11 / 04 / 92$ & .8 & .10 & $<.01$ & $<.01$ & .08 & NA \\
\hline & $12 / 03 / 92$ & 1.3 & .09 & .05 & $<.01$ & .07 & NA \\
\hline & $01 / 26 / 93$ & $<.1$ & .02 & $<.01$ & $<.01$ & $<.01$ & NA \\
\hline & $05 / 20 / 93$ & 2.4 & .02 & .02 & .01 & .04 & NA \\
\hline & $07 / 28 / 93$ & 2.0 & .02 & .02 & .01 & .02 & NA \\
\hline
\end{tabular}


Table 11. Quality-assurance/quality-control data for major-ion, nutrient, iron, and manganese analyses

[QA/QC, quality assurance/quality control; milligram per liter; ND, not determined; <, less than]

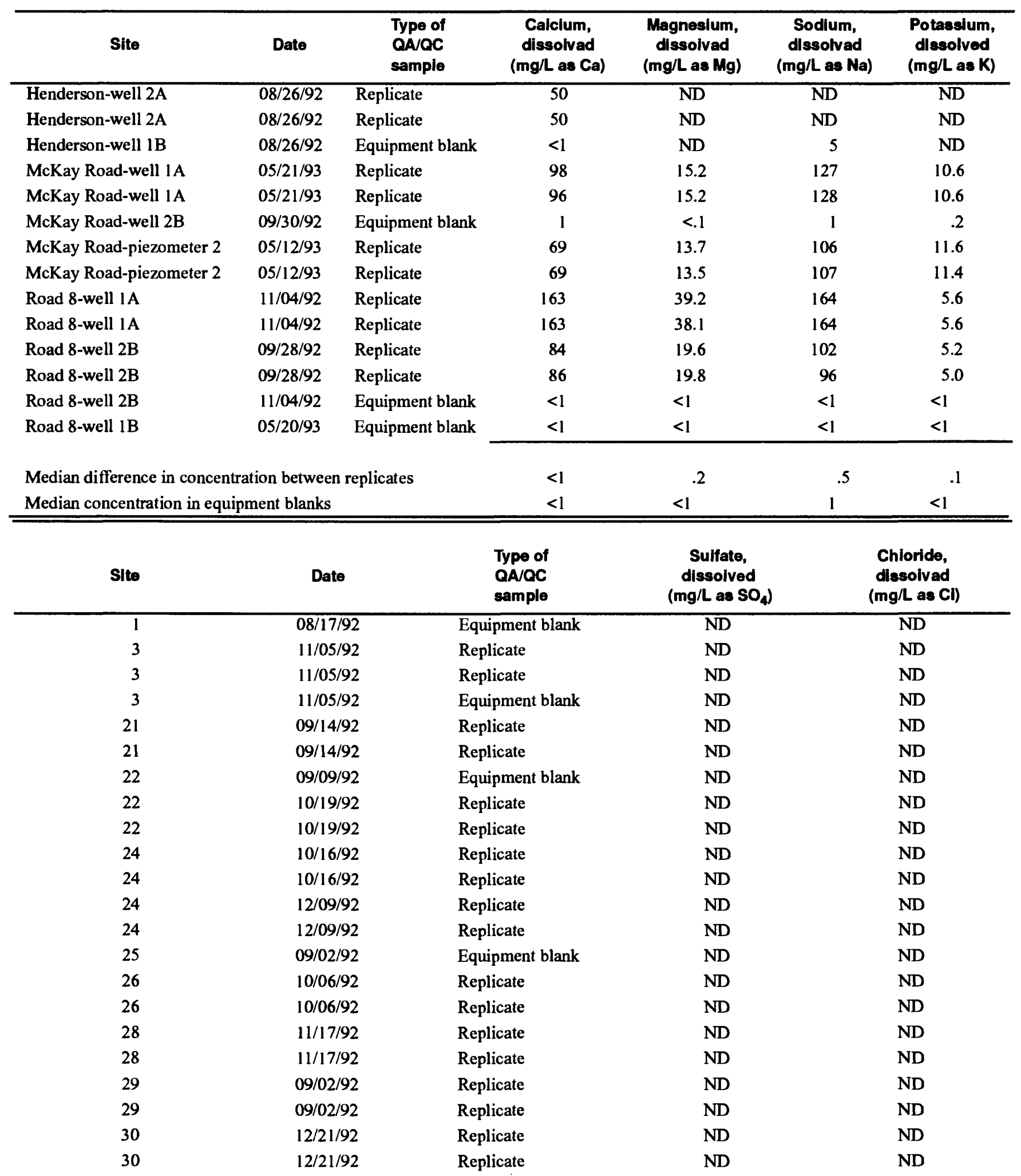

68 Quantity and Quality of Ground-Water Discharge to the South Platte RIver, Denver to Fort Lupton, Colorado, August 1992 Through July 1993 
Table 11. Quality-assurance/quality-control data for major-ion, nutrient, iron, and manganese analyses--Continued

\begin{tabular}{|c|c|c|c|c|c|c|}
\hline Site & \multicolumn{2}{|l|}{ Date } & $\begin{array}{l}\text { Type of } \\
\text { QANCC } \\
\text { sample }\end{array}$ & $\begin{array}{c}\text { Sulfate, } \\
\text { dissolved } \\
\left(\mathrm{mg} / \mathrm{L} \text { as } \mathrm{SO}_{4}\right)\end{array}$ & \multicolumn{2}{|r|}{$\begin{array}{l}\text { Chloride, } \\
\text { dlseolved } \\
\text { (mg/L as Cl) }\end{array}$} \\
\hline Henderson-well 2A & $08 / 26 / 92$ & \multicolumn{2}{|c|}{ Replicate } & ND & \multicolumn{2}{|r|}{46} \\
\hline Henderson-well 2A & $08 / 26 / 92$ & \multicolumn{2}{|c|}{ Replicate } & ND & \multicolumn{2}{|r|}{46} \\
\hline Henderson-well 1B & $08 / 26 / 92$ & \multicolumn{2}{|c|}{ Equipment blank } & 9 & \multicolumn{2}{|r|}{$<1$} \\
\hline McKay Road-well IA & $05 / 21 / 93$ & \multicolumn{2}{|c|}{ Replicate } & 197 & \multicolumn{2}{|r|}{130} \\
\hline McKay Road-well IB & $11 / 05 / 92$ & \multicolumn{2}{|c|}{ Replicate } & ND & \multicolumn{2}{|r|}{ ND } \\
\hline McKay Road-well IB & $11 / 05 / 92$ & \multicolumn{2}{|c|}{ Replicate } & ND & \multicolumn{2}{|r|}{ ND } \\
\hline McKay Road-well 2B & $09 / 30 / 92$ & \multicolumn{2}{|c|}{ Equipment blank } & 4 & & $<1$ \\
\hline McKay Road-piezometer 2 & $05 / 12 / 93$ & Repl & & 174 & & 88 \\
\hline McKay Road-piezometer 2 & $05 / 12 / 93$ & Repl & & 174 & & 90 \\
\hline Road 8-well IA & $11 / 04 / 92$ & Repl & & 269 & & 136 \\
\hline Road 8-well 2B & $09 / 28 / 92$ & Repl & & 193 & & 90 \\
\hline Road 8-well 2B & $09 / 28 / 92$ & Repl & & 195 & & 90 \\
\hline Road 8-well 2B & $11 / 04 / 92$ & Equi & blank & $<1$ & & $<1$ \\
\hline Road 8-well IB & $05 / 20 / 93$ & Equi & t blank & $<1$ & & $<1$ \\
\hline Median difference in concen & ation between rep & plicate samples & & 1.5 & & .5 \\
\hline Median concentration in bla & samples & & & 2 & & $<1$ \\
\hline 3 & $11 / 05 / 92$ & Replicate & ND & .05 & 2.6 & 1.5 \\
\hline 3 & $11 / 05 / 92$ & Equipment blank & $<0.01$ & $<.01$ & $<.1$ & $<.1$ \\
\hline 21 & $09 / 14 / 92$ & Replicate & .03 & 2.81 & .8 & 2.0 \\
\hline 21 & $09 / 14 / 92$ & Replicate & ND & 2.97 & .8 & 1.3 \\
\hline 22 & $09 / 09 / 92$ & Equipment blank & $<.01$ & $<.01$ & .2 & $<.1$ \\
\hline 22 & $10 / 19 / 92$ & Replicate & ND & 1.69 & 2.1 & 2.4 \\
\hline 22 & 10/19/92 & Replicate & ND & 1.70 & 2.2 & 2.3 \\
\hline 24 & $10 / 16 / 92$ & Replicate & ND & 1.62 & 1.3 & 1.7 \\
\hline 24 & $10 / 16 / 92$ & Replicate & ND & 1.67 & 1.5 & 2.0 \\
\hline 24 & $12 / 09 / 92$ & Replicate & $<.01$ & 1.26 & 3.8 & 4.3 \\
\hline 24 & $12 / 09 / 92$ & Replicate & $<.01$ & 4.10 & 4.0 & 4.3 \\
\hline 25 & 09/02/92 & Equipment blank & ND & $<.01$ & $<.1$ & .5 \\
\hline 26 & $10 / 06 / 92$ & Replicate & ND & 3.41 & $<.1$ & .5 \\
\hline 26 & $10 / 06 / 92$ & Replicate & ND & 3.65 & .1 & .3 \\
\hline 28 & $11 / 17 / 92$ & Replicate & $<.01$ & 4.99 & .2 & .7 \\
\hline 28 & $11 / 17 / 92$ & Replicate & $<.01$ & 4.88 & $<.1$ & .6 \\
\hline
\end{tabular}


Table 11. Quality-assurance/quality-control data for major-ion, nutrient, iron, and manganese analyses--Continued

\begin{tabular}{|c|c|c|c|c|c|c|}
\hline Slte & Date & $\begin{array}{l}\text { Type of } \\
\text { QANCC } \\
\text { sample }\end{array}$ & $\begin{array}{c}\text { Nitrite, } \\
\text { dissoivad } \\
\text { ( } \mathrm{NO}_{2}, \\
\mathrm{mg} / \mathrm{L} \text { as } \mathrm{N} \text { ) }\end{array}$ & $\begin{array}{c}\text { Nitrite } \\
\text { plus nitrate, } \\
\text { dlssolvad } \\
\text { ( } \mathrm{NO}_{2}+\mathrm{NO}_{3} \text {, } \\
\text { mg/L as N) }\end{array}$ & $\begin{array}{c}\text { Ammonlum, } \\
\text { dlsesolvad } \\
\left(\mathrm{NH}_{3},\right. \\
\mathrm{mg} / \mathrm{L} \text { as } \mathrm{N})\end{array}$ & $\begin{array}{c}\text { Ammonlum } \\
\text { plus organlc } \\
\text { nltrogen, } \\
\text { dlssolvad } \\
\text { (mg/L as N) }\end{array}$ \\
\hline 29 & $09 / 02 / 92$ & Replicate & ND & 1.22 & 0.7 & 2.4 \\
\hline 29 & 09/02/92 & Replicate & ND & 1.27 & 1.0 & 1.4 \\
\hline 30 & $12 / 21 / 92$ & Replicate & ND & 3.78 & 1.7 & 2.4 \\
\hline 30 & $12 / 21 / 92$ & Replicate & ND & 4.12 & 1.7 & 2.3 \\
\hline Henderson-well 1B & $08 / 26 / 92$ & Equipment blank & $<0.01$ & .03 & $<.1$ & .5 \\
\hline McKay Road-well 1A & $05 / 21 / 93$ & Replicate & $<.01$ & $<.01$ & 4.6 & 5.1 \\
\hline McKay Road-well 1A & $05 / 21 / 93$ & Replicate & .02 & $<.01$ & 4.6 & 3.7 \\
\hline McKay Road-well 1B & $11 / 05 / 92$ & Replicate & $<.01$ & ND & 5.6 & 7.5 \\
\hline McKay Road-well IB & $11 / 05 / 92$ & Replicate & $<.01$ & ND & 5.5 & 7.4 \\
\hline McKay Road-well 2B & $09 / 30 / 92$ & Equipment blank & $<.01$ & .09 & $<.1$ & .4 \\
\hline McKay Road-piezometer 2 & $05 / 12 / 93$ & Replicate & $<.01$ & .02 & 4.7 & 7.8 \\
\hline McKay Road-piezometer 2 & $05 / 12 / 93$ & Replicate & $<.01$ & $<.01$ & 4.4 & 7.5 \\
\hline Road 8-well 1A & $11 / 04 / 92$ & Replicate & $<.01$ & 35.20 & $<.1$ & $<.1$ \\
\hline Road 8-well IA & $11 / 04 / 92$ & Replicate & $<.01$ & 34.81 & $<.1$ & $<.1$ \\
\hline Road 8-well 1A & $11 / 04 / 92$ & $\begin{array}{l}\text { U.S. Geological } \\
\text { Survey Laboratory }\end{array}$ & ND & 35 & ND & ND \\
\hline Road 8-well 2B & $09 / 28 / 92$ & Replicate & $<.01$ & .11 & 1.1 & 1.3 \\
\hline Road 8-well 2B & $09 / 28 / 92$ & Replicate & $<.01$ & .09 & 1.1 & 1.2 \\
\hline Road 8-well 2B & $11 / 04 / 92$ & Equipment blank & $<.01$ & $<.01$ & .5 & $<.1$ \\
\hline Road 8-well 1B & $05 / 20 / 93$ & Equipment blank & $<.01$ & $<.01$ & $<.1$ & .9 \\
\hline \multicolumn{3}{|c|}{ Median difference in concentration between replicate samples } & $<.01$ & .05 & .1 & .15 \\
\hline \multicolumn{3}{|c|}{ Median concentration in blank samples } & $<.01$ & $<.01$ & $<.1$ & .4 \\
\hline
\end{tabular}

\begin{tabular}{|c|c|c|c|c|c|c|}
\hline Site & Date & $\begin{array}{l}\text { Type of } \\
\text { QAOC } \\
\text { sample }\end{array}$ & $\begin{array}{c}\text { Total } \\
\text { phosphorus, } \\
\text { dissolvad } \\
\text { (mg/L as P) }\end{array}$ & $\begin{array}{c}\text { Ortho- } \\
\text { phosphate, } \\
\text { dlssolved } \\
\text { (PO, } \\
\text { mg/L as P) }\end{array}$ & $\begin{array}{c}\text { Iron, } \\
\text { dlssolved } \\
\text { (mg/L as Fe) }\end{array}$ & $\begin{array}{l}\text { Manganese, } \\
\text { dlssolvad } \\
\text { (mg/L as Mn) }\end{array}$ \\
\hline 1 & $08 / 17 / 92$ & Equipment blank & $\overline{0.06}$ & $\overline{\mathrm{ND}}$ & ND & $\overline{\mathrm{ND}}$ \\
\hline 3 & $11 / 05 / 92$ & Replicate & .80 & ND & ND & ND \\
\hline 3 & $11 / 05 / 92$ & Replicate & .69 & ND & ND & ND \\
\hline 3 & $11 / 05 / 92$ & Equipment blank & $<.01$ & 0.03 & ND & ND \\
\hline 21 & $09 / 14 / 92$ & Replicate & 1.96 & ND & ND & ND \\
\hline 21 & $09 / 14 / 92$ & Replicate & 1.87 & ND & ND & ND \\
\hline 22 & 09/09/92 & Equipment blank & .07 & $<.01$ & ND & ND \\
\hline 22 & $10 / 19 / 92$ & Replicate & .67 & ND & ND & ND \\
\hline 22 & 10/19/92 & Replicate & .68 & ND & ND & ND \\
\hline 24 & $10 / 16 / 92$ & Replicate & 2.13 & ND & ND & ND \\
\hline 24 & $10 / 16 / 92$ & Replicate & 2.31 & ND & ND & ND \\
\hline 24 & $12 / 09 / 92$ & Replicate & 2.08 & 2.09 & ND & ND \\
\hline 24 & $12 / 09 / 92$ & Replicate & 2.11 & 2.11 & ND & ND \\
\hline 25 & 09/02/92 & Equipment blank & .02 & ND & ND & ND \\
\hline 26 & $10 / 06 / 92$ & Replicate & .74 & ND & ND & ND \\
\hline
\end{tabular}


Table 11. Quality-assurance/quality-control data for major-ion, nutrient, iron, and manganese analyses--Continued

\begin{tabular}{|c|c|c|c|c|c|c|}
\hline Site & Date & $\begin{array}{l}\text { Type of } \\
\text { QAOC } \\
\text { sample }\end{array}$ & $\begin{array}{c}\text { Total } \\
\text { phosphorus, } \\
\text { dlssolved } \\
\text { (mg/L as P) }\end{array}$ & $\begin{array}{c}\text { Ortho- } \\
\text { phosphate, } \\
\text { dissolved } \\
\text { (PO } \\
\text { mg/L as P) }\end{array}$ & $\begin{array}{c}\text { Iron, } \\
\text { dissolved } \\
\text { (mg/L as Fe) }\end{array}$ & $\begin{array}{l}\text { Manganese, } \\
\text { dissolved } \\
\text { (mg/L as Mn) }\end{array}$ \\
\hline 26 & $10 / 06 / 92$ & Replicate & 0.75 & $\overline{\mathrm{ND}}$ & ND & ND \\
\hline 28 & $11 / 17 / 92$ & Replicate & 1.85 & 1.70 & ND & ND \\
\hline 28 & $11 / 17 / 92$ & Replicate & 1.79 & 1.75 & ND & ND \\
\hline 29 & 09/02/92 & Replicate & .61 & ND & ND & ND \\
\hline 29 & 09/02/92 & Replicate & .62 & ND & ND & ND \\
\hline 30 & $12 / 21 / 92$ & Replicate & 1.61 & ND & ND & ND \\
\hline 30 & $12 / 21 / 92$ & Replicate & 1.60 & ND & ND & ND \\
\hline Henderson-well IB & $08 / 26 / 92$ & Equipment blank & .05 & $<.01$ & $<0.01$ & ND \\
\hline Henderson-well 2A & $08 / 26 / 92$ & Replicate & ND & 46 & $<.01$ & ND \\
\hline Henderson-well 2A & $08 / 26 / 92$ & Replicate & ND & 46 & $<.01$ & ND \\
\hline McKay Road-well l A & $05 / 21 / 93$ & Replicate & 1.84 & 1.77 & .43 & 1.43 \\
\hline McKay Road-well IA & $05 / 21 / 93$ & Replicate & 1.86 & 1.79 & .42 & 1.40 \\
\hline McKay Road-well 1B & $11 / 05 / 92$ & Replicate & ND & ND & ND & ND \\
\hline McKay Road-well lB & $11 / 05 / 92$ & Replicate & ND & ND & ND & ND \\
\hline McKay Road-well 2B & 09/30/92 & Equipment blank & .03 & .13 & $<.01$ & $<.01$ \\
\hline McKay Road-piezometer 2 & $05 / 12 / 93$ & Replicate & 3.65 & 3.68 & .10 & 1.04 \\
\hline McKay Road-piezometer 2 & $05 / 12 / 93$ & Replicate & 3.59 & 3.68 & .14 & 1.03 \\
\hline Road 8-well 1A & $11 / 04 / 92$ & Replicate & .10 & .07 & ND & ND \\
\hline Road 8-well 1A & $11 / 04 / 92$ & Replicate & .05 & .05 & ND & ND \\
\hline Road 8-well 2B & 09/28/92 & Replicate & $<.01$ & .02 & $<.01$ & $<.01$ \\
\hline Road 8-well 2B & 09/28/92 & Replicate & $<.01$ & $<.01$ & $<.01$ & $<.01$ \\
\hline Road 8-well 2B & $11 / 04 / 92$ & Equipment blank & .06 & .06 & $<.01$ & ND \\
\hline Road 8-well 1B & $05 / 20 / 93$ & Equipment blank & $<.01$ & $<.01$ & $<.01$ & .17 \\
\hline \multicolumn{3}{|c|}{ Median difference in concentration between replicate samples } & .03 & .02 & $<.01$ & $<.01$ \\
\hline \multicolumn{3}{|c|}{ Median concentration in blank samples } & .04 & .015 & $<.01$ & $<.01$ \\
\hline
\end{tabular}

